\title{
Reallocation of foliicolous species of the genus Strigula into six genera (lichenized Ascomycota, Dothideomycetes, Strigulaceae)
}

\author{
Shu-Hua Jiang ${ }^{1}$ (D) $\cdot$ Robert Lücking $^{2}$ (D) $\cdot$ Amanda Barreto Xavier-Leite $^{3} \cdot$ Marcela E. S. Cáceres $^{4}$ (D) André Aptroot $^{5}$ (D) \\ Carlos Viñas Portilla ${ }^{6}$ Jiang-Chun Wei ${ }^{1,7}$
}

Received: 3 December 2019 / Accepted: 29 April 2020 / Published online: 12 May 2020

(c) The Author(s) 2020

\begin{abstract}
Strigula sensu lato has been previously defined based on phenotype characters as a rather broad genus including tropical to temperate species growing on a wide array of substrata. In this study, based on a multilocus phylogenetic approach, we show that foliicolous species form six well-delimited clades that correlate with diagnostic phenotype features, including thallus morphology, carbonization of the involucrellum and excipulum, ascospore dimensions, and type of macroconidia. Given the topology, with five of the six clades emerging on long stem branches, and the strong phenotypical differentiation between the clades, we recognize these at the genus level, making mostly use of previously established genus names. Four genera, namely Phylloporis, Puiggariella, Raciborskiella, and Racoplaca, are resurrected for the S. phyllogena, S. nemathora, S. janeirensis, and S. subtilissima groups, respectively, whereas one new genus, Serusiauxiella gen. nov., is introduced for a novel lineage with peculiar macroconidia. The only sequenced non-foliicolous species, S. jamesii, is not closely related to these six foliicolous lineages but clusters with Flavobathelium and Phyllobathelium, revealing it as an additional undescribed genus-level lineage being treated elsewhere. Within the new genus Serusiauxiella, three new species are described: Serusiauxiella filifera sp. nov., S. flagellata sp. nov., and $S$. sinensis sp. nov. In addition, ten new combinations are proposed: Phylloporis austropunctata comb. nov., P. radiata comb. nov., P. vulgaris comb. nov., Puiggariella confluens comb. et stat. nov., $P$. nemathora comb. nov., $P$. nigrocincta comb. nov., Racoplaca maculata comb. nov., $R$. melanobapha comb. nov., $R$. transversoundulata, and $R$. tremens comb. nov. We also report on a peculiar, previously unrecognized growth behaviour of the macroconidial appendages in Strigula s.lat.
\end{abstract}

Keywords Cephaleuros · Epiphyllous lichens · Generic classification · Higher taxa · Macroconidial appendages · Phycopeltis · Surface fixation · Trentepohlia

Electronic supplementary material The online version of this article (https://doi.org/10.1007/s13225-020-00445-7) contains supplementary material, which is available to authorized users.

Robert Lücking

r.luecking@bgbm.org

1 State Key Laboratory of Mycology, Institute of Microbiology, Chinese Academy of Sciences, Beijing 100101, China

2 Botanischer Garten und Botanisches Museum, Freie Universität Berlin, Königin-Luise-Straße 6-8, 14195 Berlin, Germany

3 Programa de Pós-Graduação em Sistemática e Evolução, CB, Universidade Federal do Rio Grande do Norte, Campus Universitário, Natal, RN 59072-970, Brazil
4 Departamento de Biociências, Universidade Federal de Sergipe, Itabaiana, Sergipe CEP: 49.500-000, Brazil

5 Laboratório de Botânica/Liquenologia, Instituto de Biociências, Universidade Federal de Mato Grosso do Sul, Avenida Costa e Silva s/n, Bairro Universitário, Campo Grande, Mato Grosso do Sul CEP: 79070-900, Brazil

6 Jardín Botánico Nacional, Universidad de La Habana, Carretera El Rocío km 31ㄹ, Calabazar, C.P. 19230 Boyeros La Habana, Cuba

7 University of Chinese Academy of Sciences, Beijing 100049, China 


\section{Introduction}

The genus Strigula s.lat. in the family Strigulaceae (Order Strigulales) comprises about 70 species (Hyde et al. 2013; Lücking et al. 2017). Strigula was first mentioned as a nomen nudum in a summary of the lichen system by Fries (1821), with reference to his Systema Mycologicum 2 years later, where Fries gave a short description (Fries 1823). It is generally assumed that Fries at that time did not include a species, and therefore Santesson (1952) selected S. smaragdula Fr. as type, a name established by Fries 7 years later (Fries 1830). In the protologue, Fries (1823: 535) explicitly cited the name Endocarpon smaragdulum (“... sed ob thallum lobatulum Endocarpi smaragduli facie inter Lichenes locatum"). The latter name had been previously introduced as E. smaragdulum Wahlenb. in Acharius (1803) and corresponds to an unrelated, saxicolous lichen currently known as Myriospora smaragdula (Wahlenb.) Nägeli ex Uloth. It is unlikely that Fries identified his material with that species, and the least nomenclaturally disruptive interpretation is that Fries made a simply comparison and did not give the foliicolous taxon a name. Hence the later introduced name Strigula smaragdula (Fries 1830) indeed is to be considered the first established name for this species.

Numerous species currently included in Strigula s.lat. were described posterior to Fries (e.g. Fée 1825; Montagne 1845; Santesson 1952; Hawksworth et al. 1980; Harris 1995; Aptroot et al. 2003; Roux and Sérusiaux 2004; Lücking 2008; McCarthy 2009a). A detailed modern account of most of the foliicolous species was given in the monograph for Flora Neotropica (Lücking 2008). The separate family Strigulaceae was introduced by Zahlbruckner (1898) for an array of partly unrelated pyrenocarpus lichens growing on leaves. Eriksson (1982) and Vézda (1984) restricted the family to three genera, Strigula, Phylloporis and Raciborskiella, a classification followed in some other works (e.g. Llarens 2003). Species assigned to Raciborskiella grow exclusively on the leaf underside, whereas species assigned to Phylloporis (and previously to Porina) are supracuticular (Santesson 1952; Vézda 1984). The subcuticular foliicolous species classified in Raciborskiella and Strigula thereby associate with photobionts in the genus Cephaleuros (Trentepohliaceae), a semiparasitic alga which obtains carbohydrates through photosynthesis but other nutrients from the host leaves (Nelson 2008; Brooks et al. 2015). While Cephaleuros appears to represent a phylogenetically coherent entity, it is nested within a broadly defined genus Trentepohlia s.lat. whose generic delimitation remains unresolved (Nelsen et al. 2011a; Zhu et al. 2014). However, these ecological differences were not accepted as being sufficient for generic delimitation, and both Phylloporis and Raciborskiella were included in Strigula (Harris 1975, 1995), a classification accepted in major works (Roux and Sérusiaux 2004; Lücking 2008; McCarthy 2009a; Lücking et al. 2017).

With this broadened generic concept, Strigula s.lat. was further emended by adding numerous corticolous and saxicolous species (Hawksworth et al. 1980; Etayo 1993; Harris 1995; McCarthy 1995, 1997, 2001, 2009a, b; McCarthy and Malcolm 1996; Roux and Sérusiaux 2004). Notably, the only non-foliicolous species thus far sequenced, the saxicolous Strigula jamesii (Swinsc.) R.C. Harris, was first described in the genus Geisleria and only later transferred to Strigula (Harris in Hawksworth et al. 1980). The type of Geisleria, G. sychnogonoides Nitschke, has been shown through molecular and morphological study to be an apotheciate taxon close to Stictidaceae and entirely unrelated to Strigulaceae (Aptroot et al. 2014). Hence the name Geisleria is not available as genus name for nonfoliicolous species of Strigula s.lat. including S. jamesii.

Strigulaceae have been analysed molecularly in various studies, including their higher level phylogenetic relationships (Nelsen et al. 2009, 2011b) and species delimitation in foliicolous representatives (Jayalal et al. 2013; Krishnamurthy and Subramanya 2016; Jiang et al. 2016, 2017a, b; Krishnamurthy and Kumar 2017). However, to date no broader systematic study of the genus based on molecular data has been carried out. Adding to the somewhat diffuse delimitation of the genus, Harris (1995) even suggested merging Phyllobathelium with Strigula, while other workers kept this genus separate (Aptroot et al. 1997; Lücking 2008; McCarthy 2009a) or placed it in a separate family, Phyllobatheliaceae (Eriksson et al. 2004; Eriksson 2005). Molecular data (Nelsen et al. 2009) supported the inclusion of Phyllobatheliaceae within Strigulaceae, but clearly separate from foliicolous lineages of Strigula. Two new genera, Phyllocratera and Flavobathelium, were also added to the family (Aptroot et al. 1997; Lücking et al. 1997; Nelsen et al. 2009). Further, the non-lichenized Oletheriostrigula (Huhndorf and Harris 1996) was transferred to Strigulaceae (Lücking et al. 2017), but based on macroconidial morphology, this placement is not justified. A recent systematic and phylogenetic analysis of some Porina-like foliicolous lichens resulted in the recognition of a novel lineage forming a new family, Tenuitholiascaceae, sister to Strigulaceae in Strigulales (Jiang et al. 2020).

In this study, we provide the first broad-scale multilocus phylogeny of Strigula s.lat. focusing on foliicolous taxa, employing markers from the rDNA (ITS, nuSSU, nuLSU) and protein-coding loci (TEF1- $\alpha$, RPB2). The results prompted us to reclassify foliicolous taxa into six well-delimited genera. 


\section{Materials and methods}

\section{Material examined}

A total of 65 specimens of Strigulales belonging to 27 species from included for the ingroup taxon set, representing material from the Americas (Brazil, Cuba, Guatemala) and Asia (China). Additional material from other regions (Costa Rica, Australia) was included for morphological comparison. Specimens examined (and duplicates) are preserved in the Fungarium-Lichenarium of the Institute of Microbiology, Chinese Academy of Sciences (HMAS-L), the herbarium of the Botanischer Garten und Botanisches Museum und Botanischer Garten Berlin (B), the Australian National Herbarium, Centre for Australian National Biodiversity Research (CANB), and the herbarium of the Jardín Botánico Nacional de Cuba in Havanna (HAJB).

\section{Morphological observations}

For morphological and anatomical studies, a LEICA M125 dissecting microscope (Leica Microsystems, Singapore) and a Zeiss Axioscope 2 compound microscope (Carl Zeiss, Göttingen) were used. Photographs were taken with an AxioCam MRc5 connected to a Zeiss Imager A2-M2 microscope (Carl Zeiss, Göttingen) for microscopic features. Thin-layer chromatography (TLC) (Orange et al. 2001) was employed for the detection of lichen substances in selected specimens. Features of the ascus apex were examined using Lugol's solution, without pre-treatment by $\mathrm{KOH}$ (Baral 1987).

\section{Molecular phylogeny of the mycobiont}

The modified CTAB method (Rogers and Bendich 1988) was used for DNA extraction. DNA, suspended in $\mathrm{ddH}_{2} \mathrm{O}$, was amplified by the polymerase chain reaction (PCR). The nuclear ribosomal RNA gene region, including internal transcribed spacers (ITS) 1 and 2 and the 5.8S subunit, was amplified using the primer pair ITS5 and ITS4 (White et al. 1990). Partial nuclear ribosomal small subunit (nuSSU) sequences were amplified using combinations of the following, mostly Strigulales-specific primers: SF5 (Jiang et al. 2020), SR5 (Jiang et al. 2020), and SR3 (newly designed here; Table 1). A portion of the fungal nuclear ribosomal large subunit (nuLSU) was amplified using combinations of the primers ITS 3 (White et al. 1990), LR72 (Jiang et al. 2020), and LR71, 28SR4R, 28BYF1, and NEWR2 (newly designed here; Table 1). Partial TEF1- $\alpha$ sequences were generated using
Table 1 Newly designed, Strigulales-specific primers for the nuSSU and nuLSU rDNA regions

\begin{tabular}{ll}
\hline Primer acronym & Primer sequence \\
\hline SR3 & GCTGCGTTCTTCATCGTTGC \\
LR71 & TACTACCACCAAGATCTGC \\
28SR4R & TTTCTGGCACCTCTAGCCTC \\
$28 B Y F 1$ & ATGAAGAACGCGGCAAAATG \\
NEWR2 & CTAAACCCAGCTCACGTTCC \\
\hline
\end{tabular}

the primers TEF1a-983-F (Rehner and Buckley 2005) and TEF1a-1567R-HTL (Nelsen et al. 2011b). The second largest subunit of the RNA polymerase II (RPB2) was amplified using the primers fRPB2-5F and fRPB2-7cR (Liu et al. 1999).

PCR reactions were carried out in $25 \mu$ r reaction volume and the components used were $2 \mu \mathrm{l}$ total DNA, $1 \mu \mathrm{l}$ each primer $(10 \mu \mathrm{M}), 12.5 \mu \mathrm{l} 2 \times$ Taq MasterMix, $8.5 \mu \mathrm{ldd} \mathrm{d}_{2} \mathrm{O}$. Amplification was performed using a Biometra T-Gradient thermal cycler. Cycling parameters of LSU, ITS and SSU were set to an initial denaturation at $95{ }^{\circ} \mathrm{C}$ for $5 \mathrm{~min}$, followed by 35 cycles of denaturation at $94{ }^{\circ} \mathrm{C}$ for $30 \mathrm{~s}$, annealing at $54{ }^{\circ} \mathrm{C}$ for $30 \mathrm{~s}$, extension at $72{ }^{\circ} \mathrm{C}$ for $1 \mathrm{~min}$, and a final extension at $72{ }^{\circ} \mathrm{C}$ for $10 \mathrm{~min}$. PCR amplifications of TEF1- $\alpha$ were initiated with a 2 min denaturation at $94{ }^{\circ} \mathrm{C}$. The annealing temperature in the first amplification cycle was $66^{\circ} \mathrm{C}$, which was subsequently incrementally reduced by $1{ }^{\circ} \mathrm{C}$ per cycle over the next 9 cycles. An additional 30 amplification cycles were then performed, each consisting of $30 \mathrm{~s}$ denaturation at $94{ }^{\circ} \mathrm{C}$, a $30 \mathrm{~s}$ annealing step at $56^{\circ} \mathrm{C}$, and a $1 \mathrm{~min}$ extension at $72{ }^{\circ} \mathrm{C}$, concluding with a 10 min incubation at $72{ }^{\circ} \mathrm{C}$ (Rehner and Buckley 2005). The PCR conditions of RPB2 included: initial denaturation at $95{ }^{\circ} \mathrm{C}$ for $5 \mathrm{~min} ; 35$ cycles of $1 \mathrm{~min}$ at $95^{\circ} \mathrm{C}, 2 \mathrm{~min}$ at $50{ }^{\circ} \mathrm{C}$, an increase of $1{ }^{\circ} \mathrm{C} / 5$ s to $72{ }^{\circ} \mathrm{C}$, and 2 min at $72{ }^{\circ} \mathrm{C}$; and a 10 -min incubation at $72{ }^{\circ} \mathrm{C}$ (Liu et al. 1999). The PCR products were checked on $0.8 \%$ agarose electrophoresis gels stained with ethidium bromide and then sent to the sequencing facilities of Majorbiology Cooperation, China, for sequencing. Sequences were deposited in GenBank (Table 2).

New sequences generated for each locus were first analyzed separately with other sequences obtained from GenBank (Table 2). Sequences of each marker were aligned using MAFFT 7.402 (Katoh and Toh 2010) and analysed separately (see below) to evaluate potential conflicts. Conflicts were evaluated manually by comparing the topology and position of each of the major clades in relation to their topology and position in the concatenated analysis (see Results).

ML trees were reconstructed for each individual marker and for a concatenated data set including the nuSSU, nuLSU, 
Table 2 Voucher information and GenBank accession numbers for specimens of Strigulales used in the molecular phylogenetic analyses

\begin{tabular}{|c|c|c|c|c|c|c|c|c|}
\hline Species & DNA extract & Country & Collector & ITS & nuLSU & nuSSU & TEF1- $\alpha$ & $R P B 2$ \\
\hline $\begin{array}{l}\text { Flavobathelium } \\
\text { epiphyllum }\end{array}$ & MPN-67 & & & - & GU327717 & JN887382 & JN887423 & - \\
\hline $\begin{array}{l}\text { Phyllobathelium } \\
\text { anomalum }\end{array}$ & MPN-242 & & & - & GU327722 & JN887386 & JN887430 & - \\
\hline $\begin{array}{l}\text { Phylloporis cf. } \\
\text { obducta }\end{array}$ & HMAS-L0139218 & China & S.H. Jiang & - & MN720034 & MN727002 & MN738504 & MN738529 \\
\hline $\begin{array}{l}\text { Phylloporis cf. } \\
\text { obducta }\end{array}$ & HMAS-L0139247 & China & S.H. Jiang & - & MN720035 & MN727003 & MN738505 & MN738530 \\
\hline $\begin{array}{l}\text { Phylloporis cf. } \\
\text { obducta }\end{array}$ & HMAS-L0139286 & China & S.H. Jiang & - & MN720036 & MN727004 & MN738506 & MN738531 \\
\hline $\begin{array}{l}\text { Phylloporis cf. } \\
\text { obducta }\end{array}$ & HMAS-L0139339 & China & $\begin{array}{l}\text { X.L. Wei \& S.H. } \\
\text { Jiang }\end{array}$ & - & MN720037 & MN727005 & MN738507 & MN738532 \\
\hline $\begin{array}{l}\text { Phylloporis cf. } \\
\text { obducta }\end{array}$ & HMAS-L0139635 & China & S.H. Jiang & - & MN720038 & MN727006 & MN738508 & MN738533 \\
\hline $\begin{array}{l}\text { Phylloporis phyl- } \\
\text { logena }\end{array}$ & ISE-33944 & Brazil & A. B. Xavier Leite & - & MN720039 & MN727007 & MN738509 & MN738534 \\
\hline $\begin{array}{r}\text { Puiggariella } \\
\text { nemathora }\end{array}$ & ISE-32586 & Brazil & A. B. Xavier Leite & - & - & MN727009 & MN738510 & - \\
\hline $\begin{array}{r}\text { Puiggariella } \\
\text { nemathora }\end{array}$ & ISE-32794 & Brazil & A. B. Xavier Leite & - & - & MN727008 & - & MN738535 \\
\hline $\begin{array}{l}\text { Puiggariella nigro- } \\
\text { cincta }\end{array}$ & HMAS-L0139335 & China & $\begin{array}{l}\text { X.L. Wei \& S.H. } \\
\text { Jiang }\end{array}$ & - & MN720040 & MN727010 & MN738511 & MN738536 \\
\hline $\begin{array}{l}\text { Puiggariella nigro- } \\
\text { cincta }\end{array}$ & HMAS-L0139350 & China & $\begin{array}{l}\text { X.L. Wei \& S.H. } \\
\text { Jiang }\end{array}$ & - & MN720041 & MN727011 & MN738512 & MN738537 \\
\hline $\begin{array}{l}\text { Puiggariella nigro- } \\
\text { cincta }\end{array}$ & HMAS-L0141541 & China & $\begin{array}{l}\text { X.L. Wei \& S.H. } \\
\text { Jiang }\end{array}$ & - & MN720042 & MN727012 & MN738513 & MN738538 \\
\hline $\begin{array}{l}\text { Raciborskiella janei- } \\
\quad \text { rensis }\end{array}$ & HMAS-L0130589 & China & $\begin{array}{l}\text { J.H. Wang \& R.D. } \\
\text { Liu }\end{array}$ & - & MN720043 & MN727013 & MN738514 & - \\
\hline $\begin{array}{l}\text { Raciborskiella } \\
\text { talaumae }\end{array}$ & HMAS-L0139624 & China & S.H. Jiang & - & MN720044 & MN727014 & MN738515 & - \\
\hline $\begin{array}{l}\text { Raciborskiella } \\
\text { talaumae }\end{array}$ & HMAS-L0139627 & China & S.H. Jiang & - & MN720045 & MN727015 & MN738516 & - \\
\hline $\begin{array}{l}\text { Racoplaca mel- } \\
\text { anobapha }\end{array}$ & HMAS-L0139331 & China & $\begin{array}{l}\text { X.L. Wei \& J.H. } \\
\text { Wang }\end{array}$ & - & MN720046 & MN727016 & MN738517 & MN738539 \\
\hline $\begin{array}{l}\text { Racoplaca mel- } \\
\text { anobapha }\end{array}$ & HMAS-L0139623 & China & S.H. Jiang & - & MN720047 & MN727017 & MN738518 & MN738540 \\
\hline $\begin{array}{l}\text { Racoplaca subtilis- } \\
\quad \text { sima }\end{array}$ & ISE-32602 & Brazil & A. B. Xavier Leite & - & - & MN727018 & MN738519 & - \\
\hline $\begin{array}{l}\text { Serusiauxiella filif- } \\
\text { era } \text { sp. nov. }\end{array}$ & HMAS-L0130625 & China & $\begin{array}{l}\text { J.H. Wang \& R.D. } \\
\text { Liu }\end{array}$ & MN720009 & - & - & - & - \\
\hline $\begin{array}{l}\text { Serusiauxiella filif- } \\
\text { era sp. nov. }\end{array}$ & HMAS-L0130627 & China & $\begin{array}{l}\text { J.H. Wang \& R.D. } \\
\text { Liu }\end{array}$ & MN720010 & - & - & - & - \\
\hline $\begin{array}{l}\text { Serusiauxiella filif- } \\
\text { era sp. nov. }\end{array}$ & HMAS-L0130629 & China & $\begin{array}{l}\text { J.H. Wang \& R.D. } \\
\text { Liu }\end{array}$ & MN720011 & MN720048 & MN727019 & MN738520 & MN738541 \\
\hline $\begin{array}{l}\text { Serusiauxiella filif- } \\
\text { era sp. nov. }\end{array}$ & HMAS-L0139219 & China & S.H. Jiang & MN720019 & - & - & - & - \\
\hline $\begin{array}{l}\text { Serusiauxiella filif- } \\
\text { era sp. nov. }\end{array}$ & HMAS-L0139223 & China & S.H. Jiang & MN720020 & - & - & - & - \\
\hline $\begin{array}{l}\text { Serusiauxiella filif- } \\
\text { era sp. nov. }\end{array}$ & HMAS-L0139234 & China & S.H. Jiang & MN720022 & - & - & - & - \\
\hline $\begin{array}{l}\text { Serusiauxiella filif- } \\
\text { era sp. nov. }\end{array}$ & HMAS-L0139270 & China & $\begin{array}{l}\text { X.L. Wei \& J.H. } \\
\text { Wang }\end{array}$ & MN720012 & - & - & - & - \\
\hline $\begin{array}{l}\text { Serusiauxiella filif- } \\
\text { era sp. nov. }\end{array}$ & HMAS-L0139272 & China & $\begin{array}{l}\text { X.L. Wei \& J.H. } \\
\text { Wang }\end{array}$ & MN720013 & - & - & - & - \\
\hline
\end{tabular}


Table 2 (continued)

\begin{tabular}{|c|c|c|c|c|c|c|c|c|}
\hline Species & DNA extract & Country & Collector & ITS & nuLSU & nuSSU & TEF1- $\alpha$ & $R P B 2$ \\
\hline $\begin{array}{l}\text { Serusiauxiella filif- } \\
\text { era } \text { sp. nov. }\end{array}$ & HMAS-L0139288 & China & S.H. Jiang & MN720021 & - & - & - & - \\
\hline $\begin{array}{l}\text { Serusiauxiella filif- } \\
\text { era sp. nov. }\end{array}$ & HMAS-L0139298 & China & S.H. Jiang & MN720015 & - & - & - & - \\
\hline $\begin{array}{l}\text { Serusiauxiella filif- } \\
\text { era } \text { sp. nov. }\end{array}$ & HMAS-L0141639 & China & S.H. Jiang & MN720014 & - & - & - & - \\
\hline $\begin{array}{l}\text { Serusiauxiella filif- } \\
\text { era sp. nov. }\end{array}$ & HMAS-L0141641 & China & S.H. Jiang & MN720016 & - & - & - & - \\
\hline $\begin{array}{l}\text { Serusiauxiella filif- } \\
\text { era } \text { sp. nov. }\end{array}$ & HMAS-L0141644 & China & S.H. Jiang & MN720017 & - & - & - & - \\
\hline $\begin{array}{l}\text { Serusiauxiella filif- } \\
\text { era } \text { sp. nov. }\end{array}$ & HMAS-L0141648 & China & S.H. Jiang & MN720018 & MN720049 & MN727020 & MN738521 & MN738542 \\
\hline $\begin{array}{l}\text { Serusiauxiella filif- } \\
\text { era sp. nov. }\end{array}$ & HMAS-L0141656 & China & S.H. Jiang & MN720023 & MN720050 & MN727021 & MN738522 & MN738543 \\
\hline $\begin{array}{l}\text { Serusiauxiella filif- } \\
\text { era sp. nov. }\end{array}$ & HMAS-L0141660 & China & S.H. Jiang & MN720024 & - & - & - & - \\
\hline $\begin{array}{l}\text { Serusiauxiella flagel- } \\
\text { lata sp. nov. }\end{array}$ & HMAS-L0130554 & China & $\begin{array}{l}\text { J.H. Wang \& R.D. } \\
\text { Liu }\end{array}$ & MN720025 & - & - & - & - \\
\hline $\begin{array}{l}\text { Serusiauxiella flagel- } \\
\text { lata sp. nov. }\end{array}$ & HMAS-L0141609 & China & $\begin{array}{l}\text { J.H. Wang \& R.D. } \\
\text { Liu }\end{array}$ & MN720026 & - & - & - & - \\
\hline $\begin{array}{l}\text { Serusiauxiella flagel- } \\
\text { lata sp. nov. }\end{array}$ & HMAS-L0139216 & China & $\begin{array}{l}\text { J.H. Wang \& R.D. } \\
\text { Liu }\end{array}$ & MN720027 & - & - & - & - \\
\hline $\begin{array}{l}\text { Serusiauxiella sinen- } \\
\text { sis sp. nov. }\end{array}$ & HMAS-L0141605 & China & $\begin{array}{l}\text { J.H. Wang \& R.D. } \\
\text { Liu }\end{array}$ & MN720033 & - & - & - & - \\
\hline $\begin{array}{l}\text { Serusiauxiella sinen- } \\
\text { sis } \text { sp. nov. }\end{array}$ & HMAS-L0141611 & China & $\begin{array}{l}\text { J.H. Wang \& R.D. } \\
\text { Liu }\end{array}$ & MN720031 & MN720053 & MN727022 & MN738525 & MN738546 \\
\hline $\begin{array}{l}\text { Serusiauxiella sinen- } \\
\text { sis } \text { sp. nov. }\end{array}$ & HMAS-L0141612 & China & $\begin{array}{l}\text { J.H. Wang \& R.D. } \\
\text { Liu }\end{array}$ & MN720032 & - & - & - & - \\
\hline $\begin{array}{l}\text { Serusiauxiella sinen- } \\
\text { sis } \text { sp. nov. }\end{array}$ & HMAS-L0141614 & China & $\begin{array}{l}\text { J.H. Wang \& R.D. } \\
\text { Liu }\end{array}$ & MN720030 & - & - & - & - \\
\hline $\begin{array}{l}\text { Strigula acuticonidi- } \\
\quad \text { arum }\end{array}$ & HMAS-L0138045 & & & - & MK206236 & MK206217 & MK273083 & MK273111 \\
\hline Strigula antillarum & B-600205084 & Cuba & R. Lücking et al. & - & MN720054 & - & MN738526 & MN738547 \\
\hline $\begin{array}{l}\text { Strigula cf. atrocar- } \\
\text { poides }\end{array}$ & HMAS-L0139342 & China & $\begin{array}{l}\text { X.L. Wei \& S.H. } \\
\text { Jiang }\end{array}$ & - & MN720055 & MN727023 & MN738527 & MN738548 \\
\hline Strigula dispersa & HMAS-L0137212 & & & - & MN720056 & - & MK273097 & MK273125 \\
\hline $\begin{array}{l}\text { Strigula guangx- } \\
\text { iensis }\end{array}$ & HMAS-L0138040 & & & - & MK206256 & - & MK273103 & MK273131 \\
\hline $\begin{array}{l}\text { Strigula guangx- } \\
\quad \text { iensis }\end{array}$ & HMAS-L0138041 & & & - & MK206257 & - & MK273104 & MK273132 \\
\hline Strigula jamesii & MPN-548 & & & - & JN887404 & JN887388 & JN887432 & - \\
\hline $\begin{array}{l}\text { Strigula cf. macaro- } \\
\text { nesica }\end{array}$ & HMAS-L0130615 & & & - & MK206251 & MK206230 & MK273098 & MK273126 \\
\hline $\begin{array}{l}\text { Strigula cf. macaro- } \\
\quad \text { nesica }\end{array}$ & HMAS-L0139260 & & & - & MK206252 & MK206231 & MK273099 & MK273127 \\
\hline Strigula macrocarpa & HMAS-L0139289 & & & - & MK206241 & MK206222 & MK273088 & MK273116 \\
\hline Strigula macrocarpa & HMAS-L0141394 & & & - & MK206240 & MK206221 & MK273087 & MK273115 \\
\hline Strigula nitidula & HMAS-L0139358 & & & - & MN788374 & MN788375 & MN793983 & MN793982 \\
\hline Strigula prasina & B-600205026 & Guatemala & R. Lücking et al. & - & - & MN727024 & MN738528 & - \\
\hline $\begin{array}{l}\text { Strigula sinoaus- } \\
\text { tralis }\end{array}$ & HMAS-L0137204 & & & - & MK206249 & - & MK273096 & MK273124 \\
\hline Strigula smaragdula & HMAS-L0138066 & & & KY100296 & - & - & - & - \\
\hline Strigula smaragdula & HMAS-L0138068 & & & KY100299 & - & - & - & - \\
\hline
\end{tabular}


Table 2 (continued)

\begin{tabular}{|c|c|c|c|c|c|c|c|c|}
\hline Species & DNA extract & Country & Collector & ITS & nuLSU & nuSSU & TEF1- $\alpha$ & $R P B 2$ \\
\hline $\begin{array}{l}\text { Strigula cf. smar- } \\
\quad \text { agdula }\end{array}$ & HMAS-L0139166 & & & - & MK206235 & MK206216 & MK273082 & MK273110 \\
\hline $\begin{array}{l}\text { Strigula cf. smar- } \\
\text { agdula }\end{array}$ & HMAS-L0141395 & & & - & MK206234 & MK206215 & MK273081 & MK273109 \\
\hline $\begin{array}{l}\text { Strigula cf. smar- } \\
\text { agdula }\end{array}$ & HMAS-L0141396 & & & - & MK206233 & MK206214 & MK273080 & MK273108 \\
\hline $\begin{array}{l}\text { Strigula univelbise- } \\
\text { rialis }\end{array}$ & HMAS-L0137657 & & & - & MK206243 & MK206224 & MK273090 & MK273118 \\
\hline $\begin{array}{l}\text { Strigula univelbise- } \\
\text { rialis }\end{array}$ & HMAS-L0137658 & & & - & MK206245 & MK206226 & MK273092 & MK273120 \\
\hline $\begin{array}{l}\text { Strigula univelbise- } \\
\text { rialis }\end{array}$ & HMAS-L0137659 & & & - & MK206242 & MK206223 & MK273089 & MK273117 \\
\hline $\begin{array}{l}\text { Strigula univelbise- } \\
\text { rialis }\end{array}$ & HMAS-L0137660 & & & - & MK206244 & MK206225 & MK273091 & MK273119 \\
\hline $\begin{array}{l}\text { Tenuitholiascus } \\
\text { porinoides }\end{array}$ & HMAS-L0139638 & & & - & MK206259 & MK352441 & MK273106 & MK273134 \\
\hline $\begin{array}{l}\text { Tenuitholiascus } \\
\text { porinoides }\end{array}$ & HMAS-L0139639 & & & - & MK206258 & MK352442 & MK273105 & MK273133 \\
\hline $\begin{array}{l}\text { Tenuitholiascus } \\
\text { porinoides }\end{array}$ & HMAS-L0139640 & & & - & MK206260 & MK352443 & MK273107 & MK273135 \\
\hline
\end{tabular}

Newly generated sequences are indicated in boldface

TEF- $\alpha$, and RPB2. For the individual markers and the concatenated data set, we analysed two taxon sets, a broader one encompassing related Dothideomycetes (Table 3) and a narrower one focusing on Strigulales (Table 2). For this, we used IQ-TREE 1.6.6 (Nguyen et al. 2015) with 1000 bootstrap pseudoreplicates. The best-fit substitution model was selected using ModelFinder (Kalyaanamoorthy et al. 2017): TIM2 + F + I + G4 was selected as the best model for the Dothideomycetes taxon set, and TNe $+\mathrm{I}+\mathrm{G} 4$ for the Strigulales taxon set. For the ITS alignment, TN + F + G4 was selected as the best model.

Bayesian analysis was performed with MrBAYES assuming the general time reversible model including estimation of invariant sites and a discrete gamma distribution with six rate categories $(\mathrm{GTR}+\mathrm{I}+\mathrm{G})$, for the single-genes and the combined analyses (Ronquist et al. 2012). A run with 5,000,000 generations and employing 20 simultaneous chains was executed. Posterior probabilities above $90 \%$ and bootstrap support above $50 \%$ are considered significant supports. Analyses of the single markers and the combined data set resulted in basically the same topology.

Phylogenetic trees were drawn using FigTree 1.4.2 (Rambaut 2012). Alignments were submitted to TreeBase (http:// purl.org/phylo/treebase/phylows/study/TB2:S26015).

\section{Molecular phylogeny of the photobiont}

Photosymbionts of selected specimens were also analyzed phenotypically and molecularly. ITS nrDNA sequences of the algal partners were amplified using the primers nrSSU-1780-59 and nr-LSU-0012-39 (Piercey-Normore and Depriest 2001). The newly generated sequences were submitted to GenBank and aligned with fourteen samples of Trentepohliaceae from GenBank representing the three major lichenized genera currently distinguished in that family (Table 4).

The resulting alignment was subjected to randomized accelerated maximum likelihood in RAxML 8 with 1000 pseudoreplicates (Stamatakis 2014), using the GTRGAMMA model chosen by JModeltest (Felsenstein 1985; Posada 2008) and otherwise with default parameters.

\section{Results}

\section{Molecular phylogeny of the mycobiont}

Comparison between the individual markers and the concatenated data set revealed topological variation (Table 5). The Phylloporis and Raciborskiella clades were monophyletic and strongly supported in all instances (no RPB2 data for the latter); its position varied according to marker but this variation was not supported. The Puiggariella and Racoplaca clades were also consistently recovered as monophyletic with strong support (somewhat lower support for the first in TEF1- $\alpha$ ). In these cases, however, nuLSU showed a supported conflict for Puiggariella with RPB2 and the concatenated data set, whereas Racoplaca exhibited a supported 
Table 3 GenBank accession numbers for other sequences used in the molecular phylogenetic analyses

\begin{tabular}{|c|c|c|c|c|}
\hline Species & LSU & SSU & TEF1- $\alpha$ & $R P B 2$ \\
\hline Acrospermum adeanum & EU940104 & EU940031 & - & EU940320 \\
\hline Acrospermum compressum & EU940084 & EU940012 & - & EU940301 \\
\hline Acrospermum gramineum & EU940085 & EU940013 & - & EU940302 \\
\hline Aigialus grandis & GU301793 & GU296131 & - & GU371762 \\
\hline Aigialus parvus & GU301795 & GU296133 & GU349064 & GU371771 \\
\hline Aliquandostipite khaoyaiensis & GU301796 & AF201453 & GU349048 & FJ238360 \\
\hline Anisomeridium ubianum & GU327709 & JN887379 & - & - \\
\hline Apiosporina collinsii & GU301798 & GU296135 & GU349057 & - \\
\hline Aquasubmersa japonica & LC061588 & LC061583 & LC194385 & LC194422 \\
\hline Arthopyrenia salicis & AY538339 & AY538333 & - & - \\
\hline Ascocratera manglicola & GU301799 & GU296136 & - & GU371763 \\
\hline Asterina cestricola & GU586215 & GU586209 & - & - \\
\hline Asterina fuchsiae & GU586216 & GU586210 & - & - \\
\hline Asterina phenacis & GU586217 & GU586211 & - & - \\
\hline Asterina weinmanniae & GU586218 & GU586212 & - & - \\
\hline Asterina zanthoxyli & GU586219 & GU586213 & - & - \\
\hline Aureobasidium pullulans & DQ470956 & DQ471004 & DQ471075 & DQ470906 \\
\hline Botryobambusa fusicoccum & JX646809 & JX646826 & - & - \\
\hline Botryosphaeria agaves & JX646808 & JX646825 & - & - \\
\hline Botryosphaeria dothidea & DQ678051 & DQ677998 & DQ767637 & DQ677944 \\
\hline Delitschia didyma & DQ384090 & AF242264 & - & - \\
\hline Delitschia winteri & DQ678077 & DQ678026 & DQ677922 & DQ677975 \\
\hline Dendrographa decolorans & AY548815 & AY548809 & DQ883725 & DQ883715 \\
\hline Dothidea hippophaeos & DQ678048 & U42475 & DQ677887 & DQ677942 \\
\hline Dothidea insculpta & DQ247802 & DQ247810 & DQ471081 & AF107800 \\
\hline Dothidea sambuci & AY544681 & AY544722 & DQ497606 & KT216559 \\
\hline Dothiora cannabinae & DQ470984 & DQ479933 & DQ471107 & DQ470936 \\
\hline Dyfrolomyces rhizophorae & GU479799 & GU479766 & GU479860 & - \\
\hline Dyfrolomyces tiomanensis & КС692156 & KC692155 & KC692157 & - \\
\hline Elsinoe centrolobi & DQ678094 & DQ678041 & DQ677934 & - \\
\hline Elsinoe phaseoli & DQ678095 & DQ678042 & DQ677935 & - \\
\hline Elsinoe veneta & DQ767658 & DQ767651 & DQ767641 & - \\
\hline Falciformispora lignatilis & GU371826 & GU371834 & GU371819 & - \\
\hline Fal. senegalensis & KF015627 & KF015634 & KF015688 & KF015716 \\
\hline Fal. tompkinsii & KF015625 & KF015640 & KF015685 & KF015718 \\
\hline Gibbera conferta & GU301814 & GU296150 & GU349041 & - \\
\hline Gloniopsis praelonga & FJ161195 & FJ161154 & FJ161103 & FJ161113 \\
\hline Glonium circumserpens & FJ161200 & FJ161160 & FJ161108 & FJ161126 \\
\hline Glonium stellatum & FJ161179 & FJ161140 & FJ161095 & - \\
\hline Hysteropatella clavispora & AY541493 & DQ678006 & DQ677901 & DQ677955 \\
\hline Jahnula aquatica & EF175655 & EF175633 & - & - \\
\hline Jahnula bipileata & EF175657 & EF175635 & - & - \\
\hline Kirschsteiniothelia aethiops & AY016361 & AY016344 & DQ677884 & DQ470914 \\
\hline Kirschsteiniothelia lignicola & HQ441568 & HQ441569 & - & - \\
\hline Lecanactis abietina & AY548812 & AY548805 & - & DQ987635 \\
\hline Lepidosphaeria nicotiae & DQ678067 & - & DQ677910 & DQ677963 \\
\hline Lichenoconium aeruginosum & HQ174269 & - & - & - \\
\hline Lichenoconium erodens & HQ174267 & - & - & - \\
\hline Lichenoconium lecanorae & HQ174263 & - & - & - \\
\hline Lichenoconium usneae & HQ174265 & - & - & - \\
\hline Lichenothelia calcarea & KC015061 & KC015081 & - & - \\
\hline
\end{tabular}


Table 3 (continued)

\begin{tabular}{|c|c|c|c|c|}
\hline Species & LSU & SSU & TEF1- $\alpha$ & $R P B 2$ \\
\hline Lichenothelia convexa & КC015068 & КC015083 & - & - \\
\hline Lindgomyces breviappendiculata & AB521748 & AB521733 & - & - \\
\hline Lindgomyces ingoldianus & AB521736 & AB521719 & - & - \\
\hline Lophiotrema neoarundinaria & AB524596 & AB524455 & AB539110 & AB539097 \\
\hline Macrophomina phaseolina & DQ678088 & DQ678037 & DQ677929 & KX463996 \\
\hline Massariosphaeria grandispora & GU301842 & GU296172 & GU349036 & GU371725 \\
\hline Massariosphaeria typhicola & GU301844 & GU296174 & - & GU371795 \\
\hline Megalotremis verrucosa & GU327718 & JN887383 & - & - \\
\hline Microthyrium microscopicum & GU301846 & GU296175 & GU349042 & GU371734 \\
\hline Microxyphium aciculiforme & GU301847 & GU296176 & GU349045 & GU371736 \\
\hline Microxyphium theae & GU301849 & GU296178 & GU349060 & - \\
\hline Myriangium duriaei & DQ678059 & AY016347 & DQ677900 & DQ677954 \\
\hline Myriangium hispanicum & GU301854 & GU296180 & GU349055 & GU371744 \\
\hline Mytilinidion resinicola & FJ161185 & FJ161145 & - & - \\
\hline Mytilinidion scolecosporum & FJ161186 & FJ161146 & FJ161102 & FJ161121 \\
\hline Natipusilla bellaspora & JX474863 & JX474868 & - & - \\
\hline Natipusilla decorospora & HM196369 & HM196376 & - & - \\
\hline Natipusilla limonensis & HM196370 & HM196377 & - & - \\
\hline Natipusilla naponensis & HM196372 & HM196379 & - & - \\
\hline Neofusicoccum parvum & AY928045 & EU673151 & - & FJ900618 \\
\hline Neofusicoccum ribis & DQ678053 & DQ678000 & DQ677893 & EU339554 \\
\hline Oedohysterium insidens & GQ221882 & GU323190 & - & GU371785 \\
\hline Ophiosphaerella sasicola & AB524599 & AB524458 & AB539111 & AB539098 \\
\hline Phaeotrichum benjaminii & AY004340 & AY016348 & DQ677892 & DQ677946 \\
\hline Phyllosticta citricarpa & GU301815 & GU296151 & GU349053 & KY855864 \\
\hline Pseudotetraploa curviappendiculata & AB524608 & AB524467 & - & - \\
\hline Rasutoria tsugae & EF114705 & EF114730 & - & - \\
\hline Roccella fuciformis & AY584654 & AY584678 & - & KF036046 \\
\hline Roccella montagnei & GU138014 & AF110341 & - & DQ987665 \\
\hline Roussoella hysterioides & AB524622 & AB524481 & AB539115 & AB539102 \\
\hline Roussoella pustulans & AB524623 & AB524482 & AB539116 & AB539103 \\
\hline Sydowia polyspora & DQ678058 & DQ678005 & DQ677899 & DQ677953 \\
\hline Trichodelitschia bisporula & GU348996 & GU349000 & GU349020 & GU371802 \\
\hline Trichodelitschia munkii & DQ384096 & DQ384070 & - & - \\
\hline Triplosphaeria maxima & AB524637 & AB524496 & - & - \\
\hline Ulospora bilgramii & DQ678076 & DQ678025 & DQ677921 & DQ677974 \\
\hline Venturia inaequalis & GU301878 & GU296204 & GU349023 & - \\
\hline Westerdykella cylindrica & AY004343 & AY016355 & DQ497610 & - \\
\hline Westerdykella ornata & GU301880 & GU296208 & GU349021 & GU371803 \\
\hline
\end{tabular}

conflict in the nuSSU with the nuLSU and the concatenated data set. The Serusiauxiella clade was also consistently monophyletic with strong support, but supported conflict was detected between TEF1- $\alpha, R P B 2$ and the concatenated data set.

Finally, the Strigula s.str. clade was recovered as monophyletic with strong support in the nuSSU, RPB2 and the concatenated data set, but paraphyletic in the nuLSU and polyphyletic in TEF1- $\alpha$ (Table 5). In the latter case, the subclades behaving aberrantly were the $S$. nitidula and the $S$. prasina clades. Given that in 22 of 24 instances, including the concatenated data set, the six clades resulted monophyletic and with strong support, we use the concatenated tree as phylogenetic hypothesis for this group and interpret the few supported conflicts as the result of conflicting individual gene histories in the cases of the protein-coding markers. The few observed conflicts between the nuSSU and nuLSU cannot be attributed to individual gene histories, as both form part of the rDNA cistron that is expected to evolve in tandem. While these conflicts, and the resulting short 
Table 4 Voucher information and GenBank accession numbers for specimens of used for the molecular phylogenetic analyses of Trentepohliaceae photobionts

\begin{tabular}{|c|c|c|}
\hline Species & DNA extract & ITS \\
\hline Cephaleuros expansus & GD1318 & KX586811 \\
\hline Cephaleuros karstenii & DZ1309 & KX586781 \\
\hline Cephaleuros karstenii & DZ1312 & KX586784 \\
\hline Cephaleuros sp. from Strigula sp. & HMAS-L0130622 & MK211171 \\
\hline Cephaleuros sp. from Strigula cf. smaragdula & HMAS-L0141395 & MK211172 \\
\hline Phycopeltis aurea & YN1220 (IHB) & KР067280 \\
\hline Phycopeltis prostrata & YN1218 (IHB) & KP067283 \\
\hline Phycopeltis sp. from Teniotholiascus porinoides & HMAS-L0139638 & MK211174 \\
\hline Phycopeltis sp. from Teniotholiascus porinoides & HMAS-L0141346 & MK211173 \\
\hline Phycopeltis sp. from Phylloporis cf. obducta & HMAS-L0139220 & MN718160 \\
\hline Phycopeltis sp. from Phylloporis cf. obducta & HMAS-L0139228 & MN718161 \\
\hline Phycopeltis sp. & YN1202 & КР067279 \\
\hline Trentepohlia sp. from Serusiauxiella filifera sp. nov. & HMAS-L0130629 & MN718162 \\
\hline Trentepohlia sp. from Serusiauxiella flagellata sp. nov. & HMAS-L0139216 & MN718163 \\
\hline Trentepohlia sp. from Serusiauxiella flagellata sp. nov. & HMAS-L0130554 & MN718164 \\
\hline Trentepohlia sp. from Serusiauxiella sinensis sp. nov. & HMAS-L0141614 & MN718165 \\
\hline Trentepohlia sp. & DS22 & KC489115 \\
\hline Trentepohlia sp. & SAG118.80 & KM020078 \\
\hline Trentepohlia sp. & TreFl54 & KC489121 \\
\hline Ulva tepida & PR18 & KT374011 \\
\hline
\end{tabular}

Newly generated sequences are indicated in boldface branches in the concatenated backbone, make it challenging to evaluate the exact relationships between the six clades, they do not affect their interpretation as distinct phylogenetic entities.

For the Dothideomycetes taxon set, the concatenated alignment contained 4371 characters ( 1272 for nuLSU, 1176 for nuSSU, 886 for TEF1- $\alpha$, and 1037 for $R P B 2$. The resulting topology was similar for maximum likelihood (ML) and Bayesian analysis (Fig. 1). The analysis confirmed the placement of Strigulales with related orders in Dothideomycetes and the separation of the two families Strigulaceae and Tenuitholiascaceae (see Jiang et al. 2020). In this broad-scale analysis, foliicolous representatives of Strigula formed six clades (A-F) with strong support (between $95 \%$ and $100 \%$ BS and $100 \% \mathrm{PP})$.

For the Strigulales taxon set, with Tenuitholiascus porinoides S.H. Jiang, Lücking \& J.C. Wei as outgroup, the concatenated alignment had the same length parameters. In the resulting topology (Fig. 2), the six clades of foliicolous Strigula s.lat. were again supported (between 82 and $100 \%$ BS and $100 \%$ PP), with the same topology. The six clades were composed as follows (Fig. 1): clade A included the type species, S. smaradgula, and corresponds to Strigula s.str.; clade B represented a newly recognized group of species with peculiar macroconidia (see below), for which the name Serusiauxiella is introduced below; clade C included two hypophyllous species with large ascospores centered around Raciborskiella janeirensis (Müll. Arg.)
R. Sant., and the name Raciborskiella is available for this clade; clade D featured species with non-carbonized perithecial wall, with the name Puiggariella available; clade E comprised the species of the S. subtilissima (Fée) Müll. Arg. aggregate, for which the name Racoplaca exists; and clade F contained the supracuticular species formerly separated in the genus Phylloporis. The non-foliicolous Strigula jamesii clustered in a separate clade, sister to foliicolous Strigula s.lat., together with Flavobathelium and Phyllobathelium.

The ITS-based tree for the genus Serusiauxiella (Fig. 3) revealed three species-level lineages, with two species being closely related on shallow stem branches and one species being phylogenetically quite distinct on a long stem branch. These are formally introduced below as Ser. filifera sp. nov., Ser. flagellata sp. nov., and Ser. sinensis sp. nov. The latter two are very closely related but differ in 18 substitutions and two indels in the ITS, for a an overall similarity of $95.6 \%$, distinctly below the standard species threshold level of $98.5 \%$ (Suppl. File S1). The rather shallow topology between these two species is therefore due to the substantial differences compared to S. filifera (95 substitutions, 26 indels; $73.5 \%$ similarity) and the outgroup taxon, S. smaragdula. This indicates an unusually high interspecific and intergeneric variation in the ITS, compared to notably uniformity within species, making the ITS barcoding marker an ideal locus to delimit species in foliicolous Strigula s.lat. 
Table 5 Topology and position of major clades in foliicolous Strigula s.lat. in the four individual markers and the concatenated data set

\begin{tabular}{|c|c|c|c|c|c|c|}
\hline Lineage & Feature & nuSSU & nuLSU & TEF $1-\alpha$ & $R P B 2$ & Concatenated \\
\hline \multirow[t]{2}{*}{ Phylloporis } & Topology & Mono, LB (100\%) & Mono, LB (100\%) & Mono, LB (100\%) & Mono, LB (100\%) & Mono, LB (100\%) \\
\hline & Position & $\begin{array}{l}\text { Sister to } \\
\text { Rac + Ser + Str } \\
\text { (unsupported) }\end{array}$ & $\begin{array}{l}\text { Sister to Rac + Ser } \\
\quad(96 \%)\end{array}$ & $\begin{array}{l}\text { Sister to outgroup } \\
\text { (unsupported) }\end{array}$ & Sister to $\operatorname{Str}(90 \%)$ & $\begin{array}{l}\text { Sister to all other line- } \\
\text { ages }(97 \%)\end{array}$ \\
\hline \multirow[t]{2}{*}{ Puiggariella } & Topology & Mono, SB (100\%) & Mono, LB (100\%) & Mono, SB (87\%) & mono, LB (100\%) & Mono, SB (100\%) \\
\hline & Position & $\begin{array}{l}\text { Sister to Rac (unsup- } \\
\text { ported) }\end{array}$ & Sister to Rpl (92\%) & $\begin{array}{l}\text { Sister to Rpl (unsup- } \\
\text { ported) }\end{array}$ & Sister to Ser (73\%) & $\begin{array}{l}\text { Sister to Rac + Ser } \\
\quad(91 \%)\end{array}$ \\
\hline \multirow[t]{2}{*}{ Raciborskiella } & Topology & Mono, LB (100\%) & Mono, LB (100\%) & Mono, LB (100\%) & [No data] & Mono, LB (100\%) \\
\hline & Position & $\begin{array}{l}\text { Sister to Pui (unsup- } \\
\text { ported) }\end{array}$ & Sister to Ser $(94 \%)$ & $\begin{array}{l}\text { Sister to Ser }+ \text { Str } \\
\quad \text { (unsupported) }\end{array}$ & [No data] & Sister to Ser $(98 \%)$ \\
\hline \multirow[t]{2}{*}{ Racoplaca } & Topology & Mono, SB (100\%) & Mono, LB (100\%) & Mono, LB (100\%) & Mono, LB (100\%) & MONO, SB (100\%) \\
\hline & Position & $\begin{array}{l}\text { Sister to } S . \text { prasina } \\
\text { clade }(\mathbf{8 9 \%}) \\
\text { sister to Ser (unsup- } \\
\text { ported) }\end{array}$ & Sister to Pui (92\%) & $\begin{array}{l}\text { Sister to Pui (unsup- } \\
\text { ported) }\end{array}$ & $\begin{array}{l}\text { Sister to Pui }+ \text { Ser } \\
\quad \text { (unsupported) }\end{array}$ & $\begin{array}{l}\text { SISTER to } \\
\text { Pui + Rac + Ser } \\
(95 \%)\end{array}$ \\
\hline \multirow[t]{2}{*}{ Serusiauxiella } & Topology & Mono, LB (100\%) & Mono, LB (100\%) & Mono, LB (100\%) & Mono, LB (100\%) & Mono, LB (100\%) \\
\hline & Position & $\begin{array}{l}\text { Sister to } \mathrm{Rpl}+S . \\
\text { prasina clade } \\
\text { (unsupported) }\end{array}$ & Sister to Rac (94\%) & $\begin{array}{l}\text { Sister to Str core } \\
\quad(\mathbf{7 0 \%})\end{array}$ & Sister to Pui (73\%) & Sister to Rac (98\%) \\
\hline \multirow[t]{2}{*}{ Strigula s.str. } & Topology & $\begin{array}{l}\text { Mono, SB }(100 \%) \\
\quad \text { (except S. prasina } \\
\text { clade) }\end{array}$ & $\begin{array}{l}\text { Paraphyletic (unsup- } \\
\text { ported) }\end{array}$ & $\begin{array}{l}\text { Poly, SB (unsup- } \\
\text { ported) }\end{array}$ & Mono, SB (98\%) & Mono, SB (95\%) \\
\hline & Position & $\begin{array}{l}\text { Sister to } \\
\text { Rpl }+ \text { Ser }+S \\
\text { prasina clade }(80 \%)\end{array}$ & $\begin{array}{l}\text { MOSTLY basal to } \\
\text { Phy + Rac + Ser; } \\
\text { S. prasina and } S \text {. } \\
\text { nitidula clades } \\
\text { separate from core } \\
\text { (unsupported) }\end{array}$ & $\begin{array}{l}\text { Core sister to Ser } \\
(70 \%) ; \text { S. nitidula } \\
\text { and S. prasina } \\
\text { clades sister to } \\
\text { Pui + Rpl }(78 \%)\end{array}$ & Sister to Phy $(90 \%)$ & $\begin{array}{l}\text { Sister to } \\
\text { Pui + Rac + Rpl + Ser } \\
(97 \%)\end{array}$ \\
\hline
\end{tabular}

Supported conflict of individual markers with the concatenated data set is highlighted in boldface

Phy Phylloporis clade, Pui Puiggariella clade, Rac Raciborskiella clade, Rpl Racoplaca clade, Ser Serusiauxuella clade, Str Strigula s.str. clade

\section{Morphology and anatomy of foliicolous Strigula s.lat}

Specimens of Strigula s.lat. examined in this study are all characterized by a Strigula-type ascus apex, i.e. bitunicate, with a short tholus or ocular chamber at the tip, by which this clade can be distinguished from the sister group Тenuitholiascaceae (Jiang et al. 2020). As outlined above, the six foliicolous Strigula clades correlate with various phenotype characters, including photobiont type, thallus disposition, perithecial wall structure, ascospores, and macroconidida, particularly the nature of their appendages (Fig. 4).

Thallus morphology was found to be strongly correlated with phylogeny. Apart from the supracuticular species in clade F (Phylloporis), the subcuticular species in the remaining five clades exhibit four distinctive thallus types: clades A (Strigula s.str.) and B (Serusiauxiella) feature mostly thickened, bright green to grey-green thalli, whereas clade $\mathrm{C}$ (Raciborskiella) has very thin, bluish grey thalli composed of dispersed patches and clade E (Racoplaca) includes species with olive-brown to dark olive-green, somewhat metallic thalli forming delicate lobes delimited by thin black, continuous or interrupted lines. Finally, clade D (Puiggariella) includes closely related species with a continuous to lobed, pale greenish thallus with somewhat folded surface and abundant white papillae.

The involucrellum of the perithecia is mostly carbonized to various degrees but consistently uncarbonized in clade $\mathrm{D}$ (Puiggariella). Ascospores show similar variation in most clades, ranging from small to medium-sized (less than $30 \mu \mathrm{m}$ long) and in shape from oblong to fusiform. Exceptions are clade C (Raciborskiella), with large ascospores (30-70 $\mu \mathrm{m}$ long), and clade $\mathrm{F}$ (Phylloporis), with consistently small ascospores (up to $12 \mu \mathrm{m}$ ). The ascospores of Raciborskiella also display terminal gelatinous appendages. Likewise, macroconidial appendages vary from short to medium-sized in clade A, C, D, and E, whereas clade B (Serusiauxiella) is characterized by a peculiarity of its macronidial appendages. To elucidate this, we examined appendage length for the various lineages. Apparently, fresh mounts of any of the species in Strigula s.lat. feature macroconidia with rather short appendages only (15-25 $\mu \mathrm{m})$. Depending on the lineage, after a given time period, these appendages may grow 


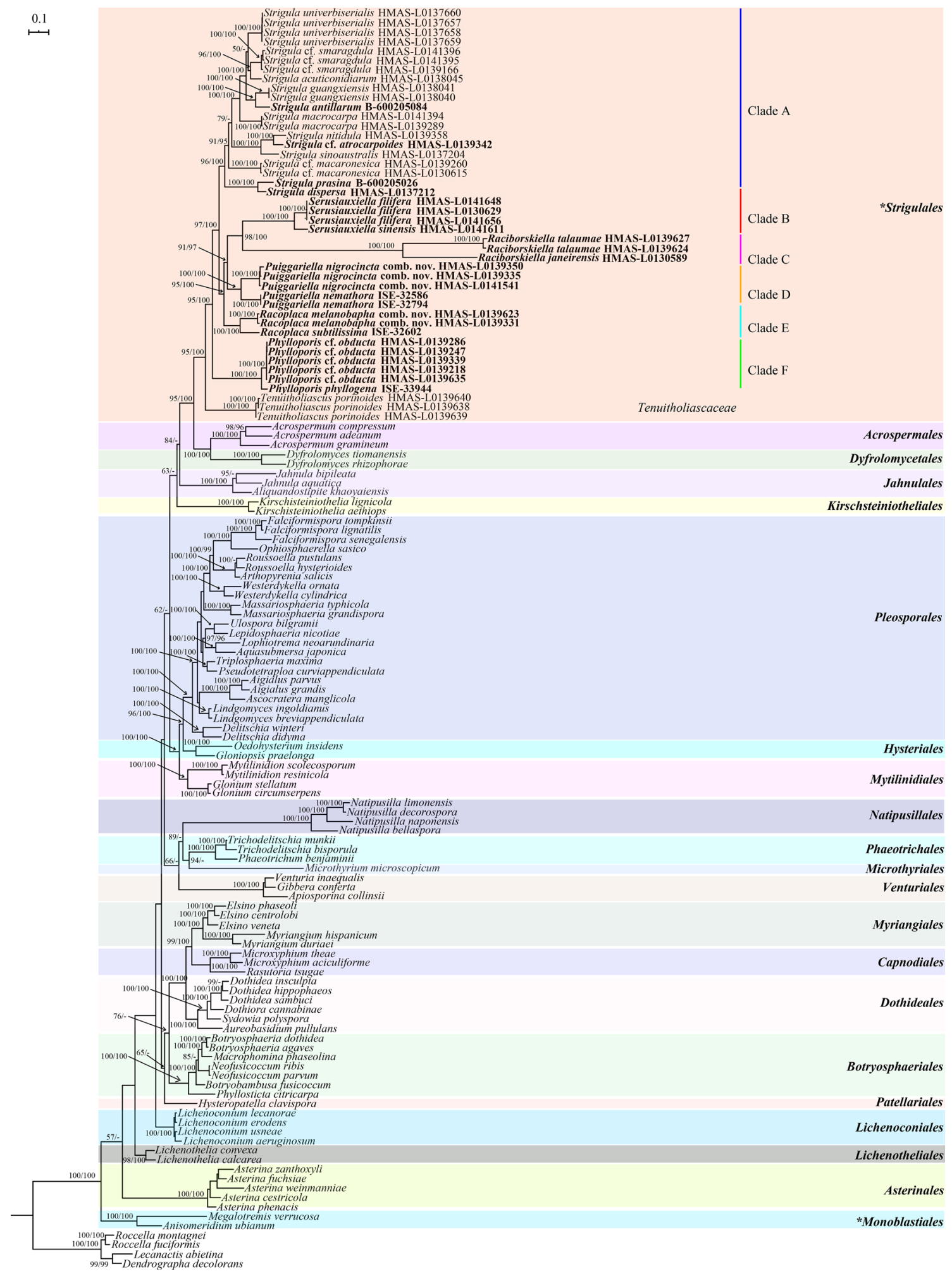

Fig. 1 Phylogenetic tree showing the delimitation of Strigulales, constructed through ML analysis in Dothideomycetes based on four markes (SSU, LSU, TEF1- $\alpha$, and RPB2) with an alignment length of $4371 \mathrm{bp}$. Maximum likelihood bootstrap probabilities above $50 \%$ (left) and Bayesian inference posterior probabilities above $90 \%$ (right) are shown at nodes (ML-BP/B-PP). Families and orders including lichenized taxa are marked with $*$. The tree was rooted with class Arthoniomycetes 


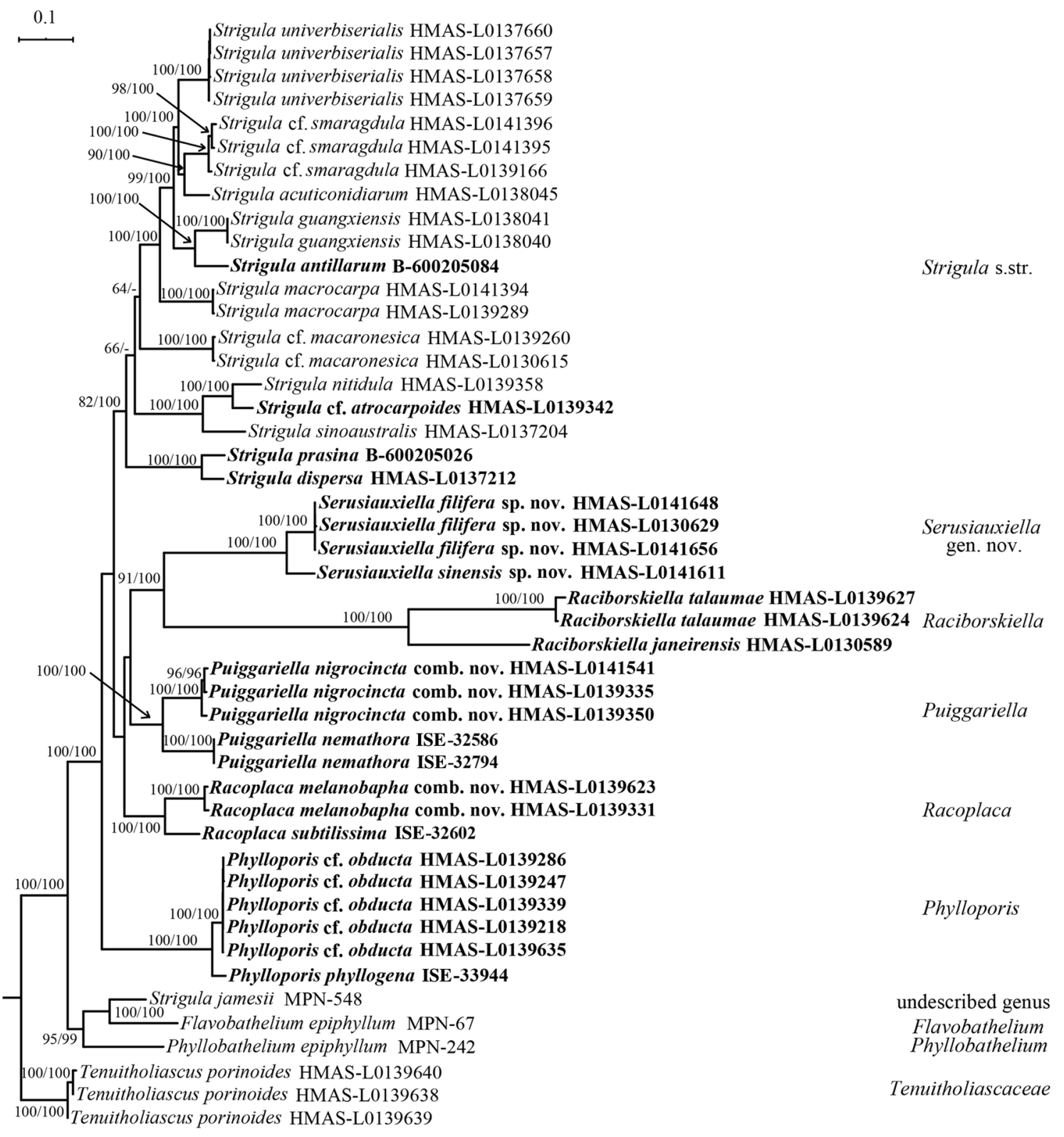

Fig. 2 Phylogenetic tree showing the internal phylogeny of Strigulaceae, constructed through ML analysis based on four markers (SSU, LSU, TEF1- $\alpha$, and RPB2) with an alignment length of 4371 bp. Maximum likelihood bootstrap support above $50 \%$ (left)

to considerable lengths. In all genera except Serusiauxiella, little change in appendage length was observed after $1 \mathrm{~h}$, but after 1 day, appendages would often have extended to $50 \mu \mathrm{m}$ or more. In contrast, in all species of Serusiauxiella, the appendages extended to up to $70 \mu \mathrm{m}$ already after $1 \mathrm{~h}$, much faster and to greater lengths than in the other genera. The functional role of this behaviour is unclear; since the appendages supposedly not contain plasma, they cannot be considered germ tubes, but their slow to rapid growth may have to do with fixation of the macroconidia on the and Bayesian inference posterior probabilities above $90 \%$ (right) are shown at nodes (ML-BP/B-PP). The tree was rooted with Tenuitholiascus porinoides

leaf surface. Notably, the ascospores do not exhibit such a behaviour.

\section{Photobiont of selected foliicolous Strigula s.lat}

Most foliicolous Strigula s.lat. clades (Puiggariella, Raciborskiella, Racoplaca, Strigula) feature a Cephaleuroslike photobiont (Fig. 5a), with anastomosing filaments or groups of cells usually arranged in one to several layers; these lichens grow subcuticularly and are not separable 
Fig. 3 Phylogenetic tree showing species delimitation in Serusiauxiella, constructed through ML analysis based on ITS sequences with an alignment length of $447 \mathrm{bp}$. Maximum likelihood bootstrap probabilities above $50 \%$ (left) and Bayesian inference posterior probabilities above $90 \%$ (right) are shown at nodes (ML-BP/B$\mathrm{PP})$. The tree was rooted with Strigula smaragdula

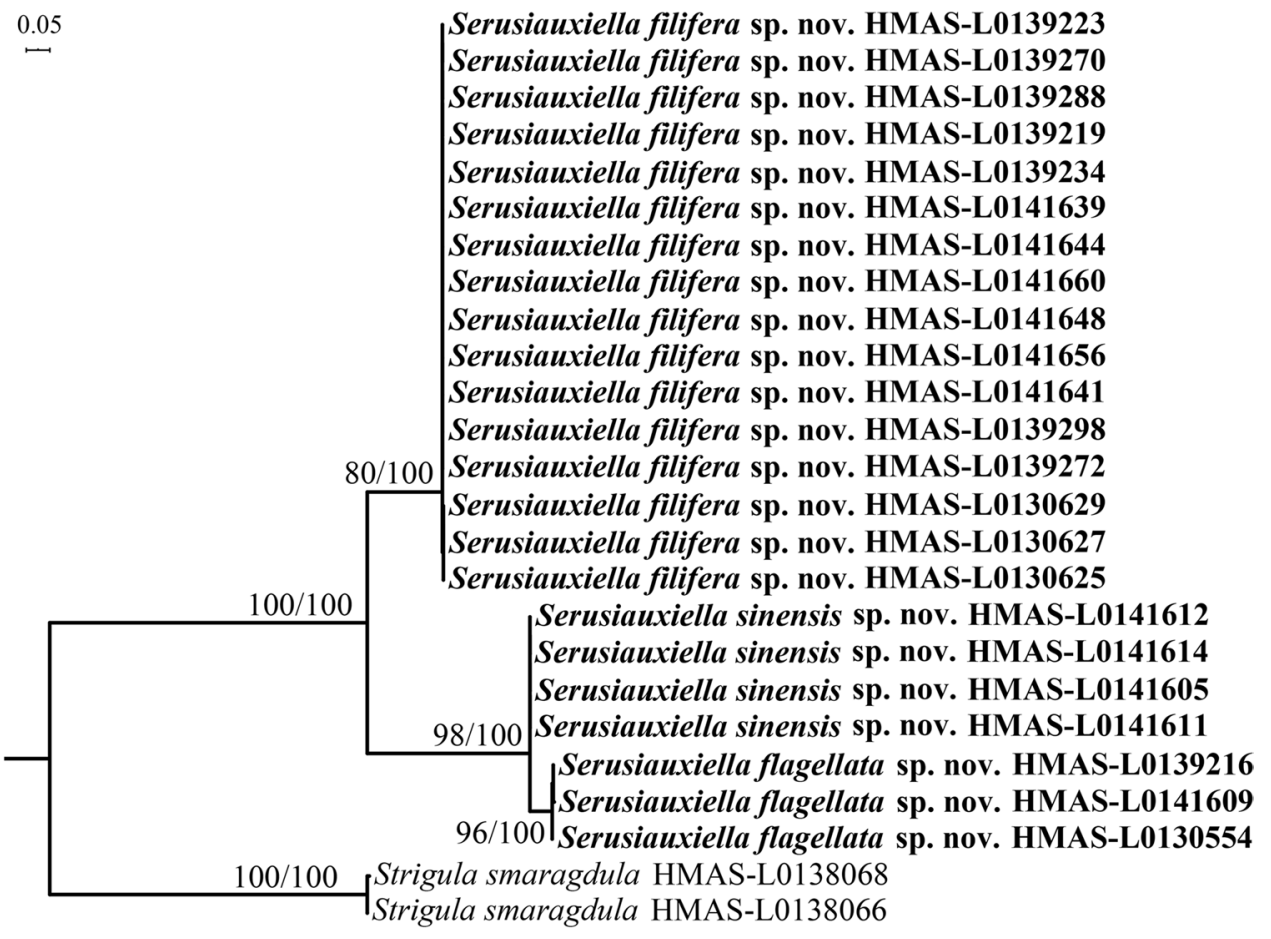

from the leaf. The Phylloporis clade features Phycopeltis as photobiont, which anastoming filaments in one layer and forming regular radiating plates or irregular nets (Fig. 5b); these lichens grow supracuticularly and can be easily separated from the leaf surface. A different, more Trentepohlia-like photobiont (Fig. 5c) was found in Serusiauxiella, which is remarkable as these species exhibit a similar thallus morphology and subcuticular growth as in Strigula s.str. Notably, thalli of Serusiauxiella can be removed from the leaf surface more easily than Strigula s.str. and the other subcuticular genera.

ITS sequence data confirmed our morpho-anatomical assessment of the photobionts, placing the photobionts of the studied lichens variously in proximity to lineages classified as Cephaleuros, Phycopeltis, or Trentepohlia (Fig. 6). However, these generic assignments are provisional, given that broader studies on trentepohlioid algae indicate that of the morphologically delimited genera within Trentepohliaceae, only Cephaleuros and Stromatochroon are monophyletic and the others (Phycopeltis, Printzina, Trentepohlia) are polyphyletic (Nelsen et al. 2011a; Zhu et al. 2017).

\section{Assessment of non-foliicolous Strigula s.lat}

The only non-foliicolous species of Strigula s.lat. sequenced thus far, Strigula jamesii, grows on rocks and is characterized by having 3 -septate ascospores, with the second cell often the widest and 3-septate macroconidia (Swinscow 1967; Roux and Sérusiaux 2004). This species does not cluster with the foliicolous taxa and the underlying topology suggests that non-foliicolous taxa do not represent Strigula s.str. or related foliicolous genera. No other generic name exists for these taxa and the name Geisleria cannot be used (see above). Given that non-foliicolous species may represent more than one entity (Roux and Sérusiaux 2004; Lücking et al. in Hyde et al. 2013), and only one species has been sequenced so far, we refrain from proposing a new genus for the single sequenced species here. The non-foliicolous species currently classified in Strigula s.lat. are being treated in a separate paper (Jiang et al., in prep.).

\section{Discussion}

Our analysis revealed the division of foliicolous Strigula s.lat. into six well-supported clades. Each clade is characterized by one or several unique synapomorphies. Clade A includes the type species Strigula smaragdula and is characterized by usually thickened, bright green to greygreen thalli with a Cephaleuros photobiont, with carbonized perithecial walls, small to medium-sized ascospores and short to medium-sized macroconidial appendages without rapid growth in microscopic mounts. Most foliicolous species of Strigula belong in this clade. Clade B is an entirely novel lineage recognized here, under the name 


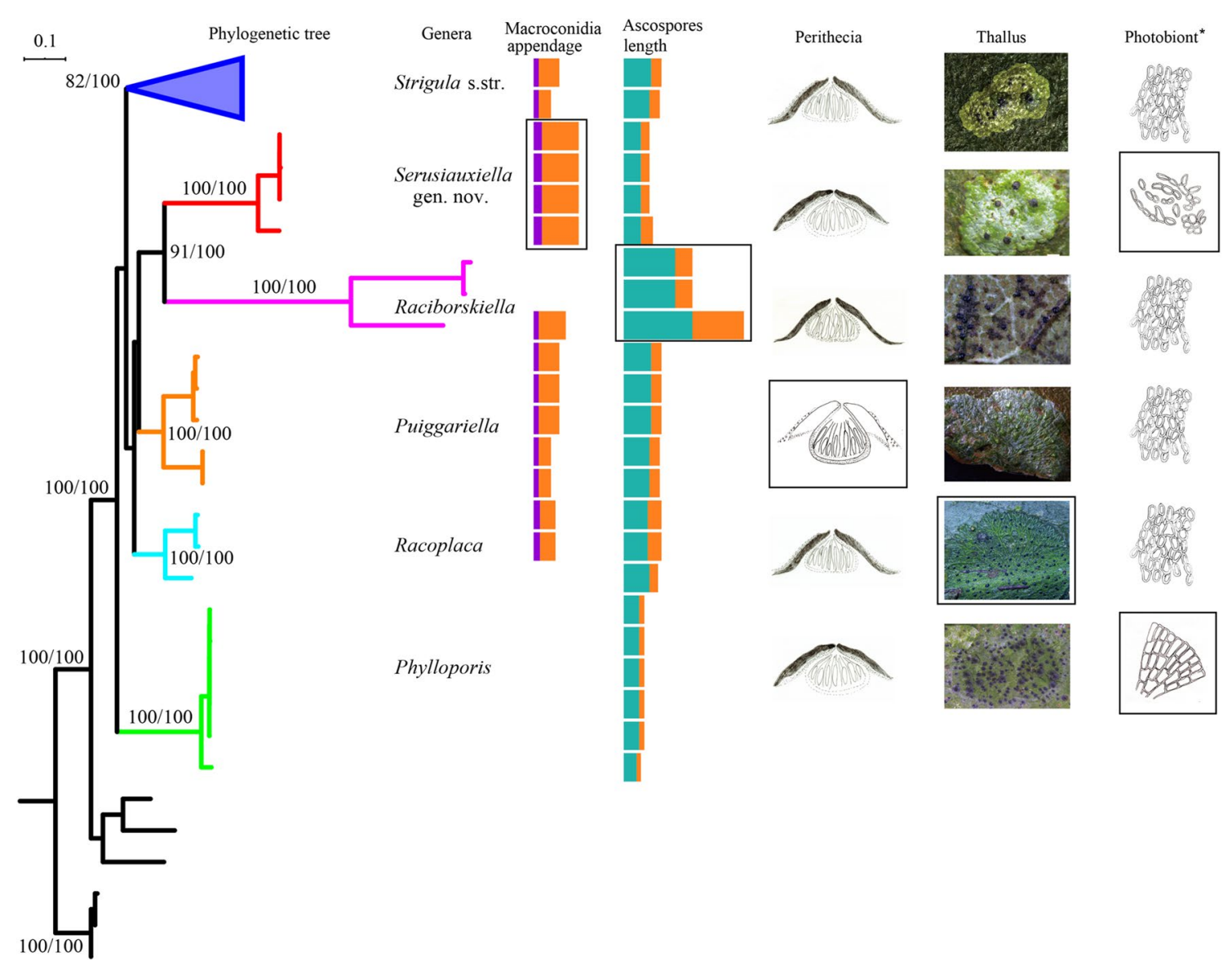

Fig. 4 Synoptic phylogenetic tree of Strigulaceae showing mapped phenotype features. The asterisk* indicates original photobiont drawings by Lücking (1992)

Serusiauxiella, on a very long stem branch, with three species new to science. The three species are morphologically rather uniform, resembling e.g. Strigula microspora Lücking in habit and ascospore size. However, the appendages of the macroconidia in this clade are unique, in microscopic mounts quickly growing to up to $70 \mu \mathrm{m}$ and making the macroconidia appear as if suspended on long, gelatinous strands. In addition, the photobiont in this clade appears to be different from other subcuticular Strigula s.lat., clustering with Trentepohlia and also morphologically resembling that genus rather than Cephaleuros. Clade C includes two species previously classified under the name Strigula janeirensis, but representing two lineages separated by ascospore size (see below). Both agree in the hypophyllous growth, forming very thin, dark bluish grey thalli with Cephaleuros photobiont, carbonized perithecial walls, large ascospores (30-70 $\times 5-7 \mu \mathrm{m}$ ), with appendages at both ends (see also Roux and Sérusiaux 1995), and macroconidia with short to medium-sized appendages. In addition, the paraphyses in this clade are slightly branched and anastomosing (Santesson 1952). These differences were not accepted for generic delimitation and therefore Raciborskiella was subsumed under Strigula (Harris 1975). However, this group is welldelimited both phylogenetically (longest branch in the tree) and phenotypically and hence the genus Raciborskiella is reinstated here. Another hypophyllous species previously included in Raciborskiella, S. prasina (Santesson 1952), has strongly deviating phenotype features fitting with Strigula s.str. (clade A) and is also included there phylogenetically.

Clade D is a small clade characterized chiefly by thallus morphology (with somewhat folded surface and abundant papillae) and pale, non-carbonized perithecial walls. The principal species in this clade, S. nemathora, is indeed quite distinct from all other foliicolous Strigula species, and our data suggest that it is a collective taxon, comprising several closely related species. The name Puiggariella is taken up for this genus. Clade E comprises the species of the Strigula subtilissima group, with thin, finely lobed thalli of olivebrown to dark (olive-)green color which feature a characteristic, thin black line along the lobe margins. Ascospores, macroconidia and other characters are otherwise similar to clade A (Strigula s.str.). The only superficially similar species in clade A is $S$. nitidula, which differs in the bright green thallus and the completely exposed, black perithecia, 
Fig. 5 a Cephaleuros sp. from Strigula smaragdula (HMASL0138067), b Phycopeltis sp. from Phylloporis cf. obducta (HMAS-L0139237), c Trentepohlia sp. from Serusiauxiella filifera. (HMAS-L0130626). Scale bars: $\mathbf{a}=20 \mu \mathrm{m}, \mathbf{b}$, $\mathbf{c}=10 \mu \mathrm{m}$
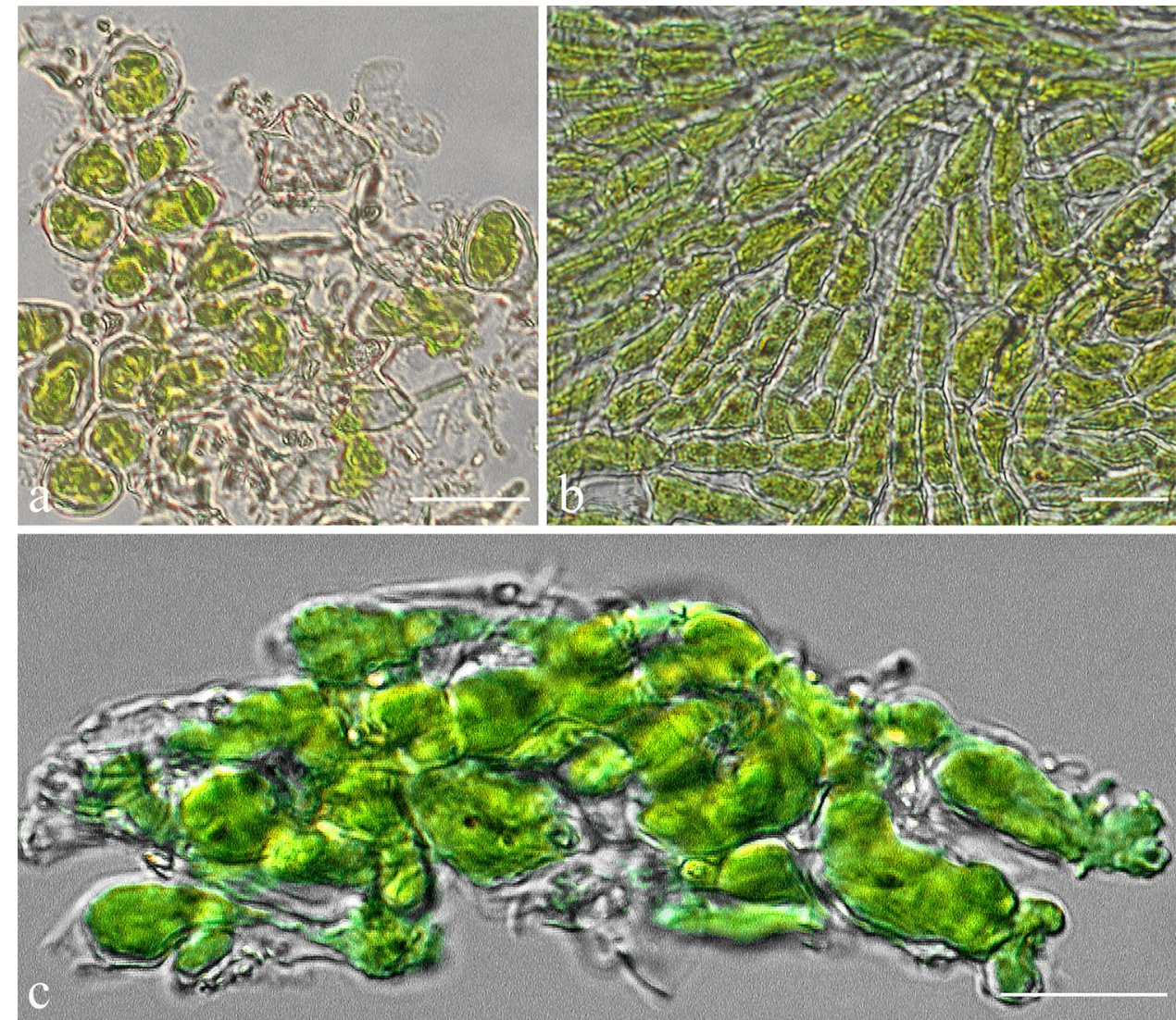

whereas those of the S. subtilissima group are covered by thallus up to the ostiole. We resurrect the name Racoplaca for this clade below. Clade F comprises the small Strigula phyllogena group, with thin, supracuticular thalli featuring a Phycopeltis photobiont, carbonized perithecial walls, and comparatively short asci and small ascospores. The genus Phylloporis was established for this group by Clements (1909), but the species were treated under Porina by Santesson (1952) and eventually included in Strigula by Harris (1995). Phylogenetically, the group is also quite distinctive. It is therefore justified to take up the genus Phylloporis for this clade.

Overall, all foliicolous lineages of Strigula s.lat. form a monophyletic clade, separate from the only non-foliicolous species currently placed in Strigula, S. jamesii. This indicates that most non-foliicolous species are not actually part of Strigula s.lat. but have to be redispositioned otherwise (Jiang et al., in prep.). For the foliicolous lineages, two alternatives exist to reflect the division into six clades taxonomically: (1) recognizing the six lineages at genus level or (2) separating them at subgeneric level. The phylogeny itself does not provide conclusive data to favor one or the other solution, although the long branches of three of the six lineages (Phylloporis, Raciborskiella, Serusiauxiella) indicate a substantial period of separate evolutionary history that would justify generic status, which in turn would then require to also recognize the other three lineages as separate genera.

The concept of the so-called "evolutionary significant unit" (ESU), in tandem with the notion that the binomial offers the inclusion of phylogenetic affinities, provides another approach to solve this matter. Originally, the term was coined to denote species- or population-level lineages that due to unique genetic makeup deserve conservation status (Moritz 1994; Casacci et al. 2014; Cornejo et al. 2017). However, the concept can be expanded to genus-level taxonomy, with the argument that ESUs above species level should be reflected in their nomenclature. The standard nomenclature for species is the binomial, including the name of the genus and the specific epithet. Infrageneric subdivisions are not reflected in the binomial and there are not established standard citation forms of infrageneric classifications in botanical or mycological nomenclature, in contrast to zoological nomenclature. Therefore, if the six lineages above would be recognized at infrageneric level (e.g. as subgenera), standard listings or name citations would not reflect this classification, as the species would continue to be listed and cited under the genus Strigula. Since these lineages strongly correlate with phenotype features and are "recognizable" as taxonomic units, we consider them 


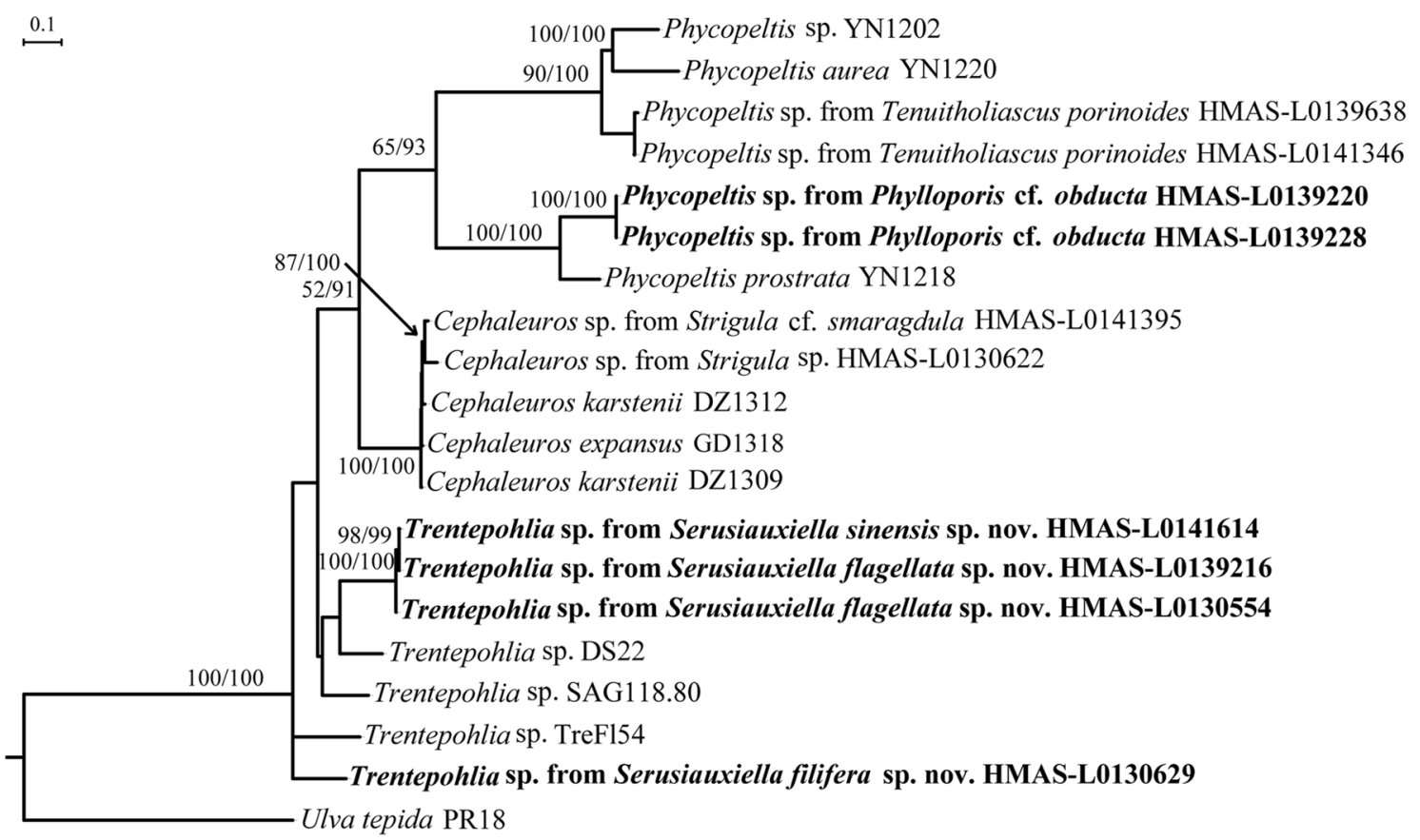

Fig. 6 Phylogenetic tree of selected Trentepohliaceae, constructed through ML analysis based on ITS. Maximum likelihood bootstrap support above $50 \%$ (left) and Bayesian inference posterior probabili-

to represent ESUs above species level and the only way to recognize this properly in their nomenclature is to establish generic rank for each lineage. We therefore introduce a revised generic concept below for foliicolous representatives of Strigula s.lat.

\section{Taxonomic treatment}

\section{Key to genera of Strigulaceae containing foliicolous species}

In the key below, genera not explicitly treated in this study are given in brackets; the remaining genera are treated in the order of the phylogeny (Fig. 1).

1. Ascospores transversely septate................... 2

1. Ascospores muriform............................ 8

2. Perithecia immersed in thalline verrucae, aggregated in pseudostromata filled with ochraceous-yellow, $\mathrm{K}+$ red crystals; paraphyses rather thick (1.5-2 $\mu \mathrm{m})$; pycnidia aggregate in pseudostromata similar to those of perithecia; macroconidia acicular, 3-5-septate, one end with gelatinous appendages, the other with gelatinous cap. . [Flavobathelium]

2. Perithecia exposed or covered by thallus layer, solitary or clustered but not in pseudostromata; pycnidia soli- ties above $90 \%$ (right) are shown at nodes (ML-BP/B-PP). The new sequences generated in this study are indicated in boldface

tary or aggregate but not in pseudostromata filled with ochraceous-yellow crystals ........................ 3

3. Perithecial wall not carbonized; thallus subcuticular, with numerous minute, white papillae 4. Puiggariella

3. Perithecia carbonized; thallus variable, very rarely with white papillae

4. Thallus supracuticular, easily separated from the leaf surface; photobiont Phycopeltis (forming radiating or reticulate plates of rectangular cells) 6. Phylloporis

4. Thallus subcuticular, more difficult to separate from the leaf surface; photobiont Cephaleuros or Trentepohlia (forming one or several layers of irregular groups or threads of angular-rounded cells) .................5

5. Ascospores large (30-70 $\mu \mathrm{m}$ long); thallus thin, typically dark bluish grey, always hypophyllous............................... 3. Raciborskiella

5. Ascospores small to medium-sized (7-25 $\mu \mathrm{m})$; thallus thin to thickened, usually bright to dark green to greygreen or olive-brown, usually epiphyllous, rarely bluish grey and/or hypophyllous ........................6

6. Thallus olive-brown to dark green, with a somewhat metallic shine, composed of dichotomously branched lacinia bordered by a continuous or interrupted black line; perithecia covered by thin thallus layer up to ostiole, therefore not pure black 5. Racoplaca

6. Thallus bright green to grey-green or rarely with bluish tinge, with entire to crenulate or lobed margin but 
rarely laciniate, not bordered by a thin black line except in the S. nitidula aggregate and then thallus green and perithecia exposed, black.......................... 7

7. Macroconidia with appendages quickly elongating (up to $70 \mu \mathrm{m}$ ) after waiting up to $1 \mathrm{~h}$ in squash mounts, often appearing as if suspended along gelatinous strands; photobiont Trentepohlia.................. 2. Serusiauxiella

7. Macroconidia with appendages remaining short to medium-sized (usually up to $30 \mu \mathrm{m}$ ) after $1 \mathrm{~h}$ in squash mounts, becoming longer only after long periods of time (1 day); photobiont Cephaleuros............ 1. Strigula s.str.

8. Perithecia immersed in thalline verrucae usually filled with black, pulveraceous crystals; pycnidia usually aggregate in pseudostromata, rarely solitary in thalline verrucae........................... [Phyllobathelium]

8. Perithecia exposed or covered by very thin thallus layer, not immersed in thalline verrucae; pycnidia usually solitary and partly exposed................ [Phyllocratera $]$

1. Strigula Fr., Syst. Mycol. (Lundae) 2(2): 535 (1823). MycoBank: MB 5285

Type: Strigula smaragdula Fr.

Notes: This more narrowly defined genus is characterized by a foliicolous growth habit forming subcuticular thalli with a Cephaleuros photobiont. The thalli are typically thickened, mostly bright green to grey-green. The perithecial wall is invariably carbonized and appears jet-black in sections. Ascospores are uniseriate to biseriate in the asci, 1 -septate (very rarely 3 -septate) and small to medium-sized $(7-25 \times 4-6 \mu \mathrm{m})$. The appendages of the macroconidia are short to medium-sized and extend only slowly in squash mounts. Most foliicolous species currently placed in Strigula s.lat. belong here, except those outlined below under the newly recognized genera.

Strigula smaragdula Fr., Linnaea 5: 550 (1830).

\section{MycoBank: MB 431363}

Type: Nepal. Unknown locality; on leaves of Loranthus ligustroides; König s.n. (lectotype, UPS!; Santesson 1952: 160 , as "holotype").

Notes: In its current taxonomic concept, Strigula smaragdula is characterized by bright green, thickened thallus patches, basally immersed and apically erumpent perithecia partly covered by a thallus layer and with a diffuse limit between the thallus and involucrellum, fusiform, 1-septate ascospores 15-25 $\times 4-6 \mu \mathrm{m}$ in size, and bacillar, 1-septate macroconidia $12-20 \times 3-4 \mu \mathrm{m}$ (Fig. 7). Several other species are similar: $S$. macrocarpa Vain. has a thinner thallus and larger, prominent perithecia; S. nigrocarpa Lücking has exposed, black perithecia sharply contrasting with the thallus, and S. subelegans Vain. has a bluish grey thallus. Strigula smaragdula is likely a collective taxon (Woo et al. 2020).
The original material is from Nepal and India; Santesson (1952) only cited the material from Nepal, as "holotype", but technically it constitures a lectotypification (ICN Art. 9.10), which means that the bulk of tropical material may not represent that species.

Distribution and ecology: Strigula smaragdula in its current circumscription is presumed to be pantropical (Santesson 1952; Lücking 2008). However, molecular studies indicate that it might deal with a collective taxon (Jiang et al. 2017a; Woo et al. 2020). For instance, the European material is now being recognized as separate species, $S$. buxi (Roux and Sérusiaux 2004). Numerous synonyms exist to potentially cover segregate species in various geographic regions (Santesson 1952; Lücking 2008). For the time being we can only confirm the presence of $S$. smaragdula in continental Asia, in accordance with the origin of the type material. From China, it was reported from five provinces (Fujian, Guizhou, Hubei, Hunan, Yunnan) by Santesson (1952). Examination on new material extends the Chinese range to Guangdong, Guangxi, Hainan, Hongkong, and Xizang provinces.

Specimens examined: CHINA. Guangdong: Shixing County, Chebaling National Nature Reserve; $24^{\circ} 42^{\prime} 35^{\prime \prime}$ N, $114^{\circ} 13^{\prime} 37^{\prime \prime}$ E, 398 m; on living leaves; 14 May 2015, X.L. Wei \& J.H. Wang GD2015031_5 (HMAS-L0139166); ibid.; $345 \mathrm{~m}$; on living leaves; 14 May 2015, X.L. Wei \& J.H. Wang GD2015025_5 (HMAS-L0138067); ibid.; 24 $42^{\prime} 39^{\prime \prime} \mathrm{N}, 114^{\circ} 13^{\prime} 30^{\prime \prime} \mathrm{E}, 387 \mathrm{~m}$; on living leaves, 15 May 2015, X.L. Wei \& J.H. Wang GD2015038_22 (HMASL0139171); ibid.; $24^{\circ} 44^{\prime} 07^{\prime \prime} \mathrm{N}, 114^{\circ} 12^{\prime} 31^{\prime \prime} \mathrm{E}, 486 \mathrm{~m}$; on living leaves, GD2015042_12 (HMAS-L0138068), GD2015042_12_3 (HMAS-L0141591). Guangxi: Nanning City, Long' an County, Longhu Mountain Natural Reserve; $22^{\circ} 57^{\prime} 42^{\prime \prime} \mathrm{N}, 107^{\circ} 37^{\prime} 40^{\prime \prime} \mathrm{E}, 147 \mathrm{~m}$, on living leaves; 1 December 2015, S.H. Jiang GX201511165 (HMAS-L0139279), GX201511084 (HMAS-L0138050). Yulin City, Beiliu County, Darongshan Nature Reserve; $22^{\circ} 51^{\prime} 46^{\prime \prime} \mathrm{N}, 110^{\circ} 16^{\prime} 31^{\prime \prime} \mathrm{E}, 495 \mathrm{~m}$, on living leaves of shrubs; 7 December 2015, S.H. Jiang GX201511037 (HMAS-L0139265), GX201511039 (HMAS-L0139266), GX201511042_2 (HMAS-L0141638), GX201511042 (HMAS-L0139267), GX201511031 (HMAS-L0139264); ibid.; 460 m; 15 December 2016, X.Q. Zhang GX2016001 (HMAS-L0139215), GX2016001_2 (HMAS-L0141630), GX2016002 (HMAS-L0139214), GX2016003 (HMAS-L0139213), GX2016004 (HMAS-L0139212), GX2016004_2 (HMAS-L0141631), GX2016005 (HMAS-L0139211), GX2016005_2 (HMAS-L0141632), GX2016005_3 (HMAS-L0141633), GX2016005_4 (HMAS-L0141636), GX2016005_5 (HMAS-L0141637), GX2016006 (HMAS-L0139209), GX2016006_2 (HMAS-L0141634), GX2016006_3 (HMAS-L0141635), GX2016007 (HMAS-L0139210). Shangsi County, Shiwan 

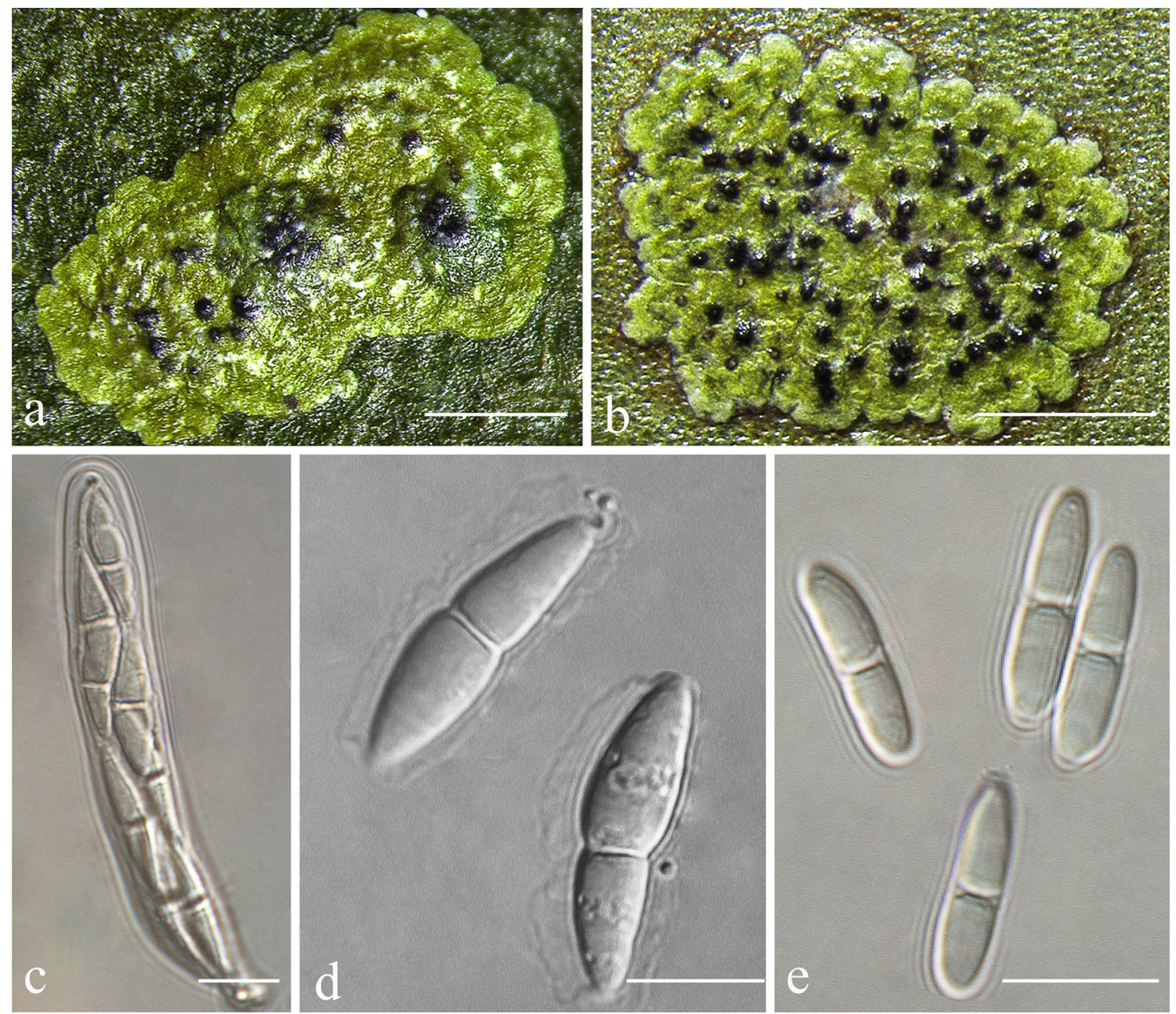

Fig. 7 Strigula smaragdula a Thallus with perithecia (HMAS-L0138067), b Thallus with pycnidia (HMAS-L0130621), c Ascus (HMASL0138066), d Ascospores (HMAS-L0138066) e Macroconidia (HMAS-L0138066). Scale bars: $\mathbf{a}, \mathbf{b}=300 \mu \mathrm{m}, \mathbf{c}-\mathbf{e}=10 \mu \mathrm{m}$

Mountain National Natural Reserve; $21^{\circ} 54^{\prime} 13^{\prime \prime} \mathrm{N}, 107^{\circ}$ 54' 13" E, 264 m; on living leaves; 5 December 2015, S.H. Jiang GX201511378 (HMAS-L0139294), GX201511378_3 (HMAS-L0141667). Longzhou County, Nonggang National Nature Reserve; $22^{\circ} 27^{\prime} 55^{\prime \prime} \mathrm{N}, 106^{\circ} 57^{\prime} 5^{\prime \prime} \mathrm{E}, 270 \mathrm{~m}$; on living leaves; 3 December 2015, S.H. Jiang, GX201511211 (HMAS-L0139316); ibid.; 268 m; 24 May 2015, X.L. Wei \& J.H. Wang GX20150197 (HMAS-L0139273); ibid.; $22^{\circ}$ $29^{\prime} 15^{\prime \prime} \mathrm{N}, 106^{\circ} 56^{\prime} 45^{\prime \prime}$ E, 268 m; 24 May 2015, X.L. Wei \& J.H. Wang GX20150188 (HMAS-L0139271); ibid.; 200 m, 23 May 2015, X.L. Wei \& J.H. Wang GX20150134 (HMAS-L0138066), GX20150137_4 (HMAS-L0141391),

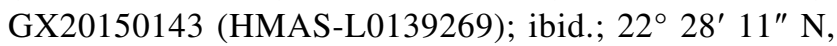
$106^{\circ} 57^{\prime} 21^{\prime \prime}$ E, 200 m; 23 May 2015, X.L. Wei \& J.H. Wang GX20150131_3 (HMAS-L0141578). Hainan, Dongfang City, Yalong village; $18^{\circ} 59^{\prime} 2^{\prime \prime} \mathrm{N}, 108^{\circ} 53^{\prime} 22^{\prime \prime} \mathrm{E}, 191 \mathrm{~m}$; on living leaves; 14 December 2014, X.L. Wei \& S.H. Jiang HN2014441_4 (HMAS-L0141624), HN2014441_5 (HMAS-L0141624), HN2014330 (HMAS-L0130621),
HN2014330_3 (HMAS-L0141621), HN2014330_4 (HMAS-L0141622), HN2014330_2 (HMAS-L0141395). Hongkong: Xinjie North District; $159 \mathrm{~m}$; on living leaves; 9 December 2011, J.C. Wei \& W. Guo HK126 (HMASL0139393), HKG-3 (HMAS-L0139394). Xizang: Motuo County, Dexing village; $29^{\circ} 42^{\prime} 48^{\prime \prime} \mathrm{N}, 95^{\circ} 36^{\prime} 43^{\prime \prime} \mathrm{E}$, $870 \mathrm{~m}$; on living leaves; 9 September 2014, X.L. Wei \& Y.Y. Wang XZ20140521 (HMAS-L0139392), XZ20140526 (HMAS-L0139398), XZ20140527 (HMAS-L0139397). Yunnan: Pu'er City, Simao District S214; 1316 m; on living leaves; 23 October 2016, X.Y. Liu YN20160044 (HMASL0139175). Xishuangbanna, Jinghong City; $22^{\circ} 19^{\prime} 15^{\prime \prime} \mathrm{N}$, $100^{\circ} 47^{\prime} 13^{\prime \prime}$ E, $968 \mathrm{~m}$; on living leaves; 28 October 2016, X.Y. Liu YN20160092 (HMAS-L0139195), YN20160096 (HMAS-L0139190). Mengla County; 21 ${ }^{\circ} 36^{\prime} 5^{\prime \prime} \mathrm{N}, 101^{\circ} 34^{\prime}$ 36" E, 678 m; on living leaves; 24 October 2016, X.Y. Liu YN20160058 (HMAS-L0139182).

2. Serusiauxiella S.H. Jiang, Lücking \& J.C. Wei, gen. nov. 
MycoBank: MB 833565

Type species: Serusiauxiella filifera S.H. Jiang, Lücking \& J.C. Wei.

Diagnosis: Differing from Strigula s.str. in the Trentepohlia photobiont and the macroconidial appendages quickly growing to substantial length (up to $70-100 \mu \mathrm{m}$ ) in squash mounts.

Etymology: It is with great pleasure that we dedicate this new genus to Dr. Emmanuël Sérusiaux, in recognition of his important contributions to lichenology, foliicolous lichens and the genus Strigula.

Description: Thallus foliicolous, crustose, forming circular patches with entire to crenulate margins, grey-green, subcuticular but more or less separable from the leaf surface. Photobiont Trentepohlia. Perithecia immersed-erumpent, hemispherical to wart-shaped; excipulum prosoplectenchymatous, colorless; involucrellum mostly carbonized, black; hamathecium colorless, I-, KI-; paraphyses unbranched or rarely sparsely branched, thin. Asci bitunicate, with short tholus and narrow, ocular chamber, I-, KI-, clavate to oblong. Ascospores 8 per ascus, biseriate or irregularly arranged, fusiform, 1 -septate, colorless, $7-15 \times 2-5 \mu \mathrm{m}$. Pycnidia immersed-erumpent, wart-shaped, black. Macroconidia bacillar to filiform, 1-septate, colorless, both ends with gelatinous appendages that grow to up to $70 \mu \mathrm{m}$ (sometimes up to $100 \mu \mathrm{m})$ in squash mounts after short time $(1 \mathrm{~h})$. Microconidia fusiform-ellipsoid, non-septate, colorless.

Chemistry: No substances detected by TLC.

Notes: As outlined above, the species of this new genus superficially resemble Strigula s.str., in particular S. microspora and similar taxa. Its most distinctive features are the macroconidial appendages becoming extremely long and the photobiont morphologically and phylogenetically representing a species of Trentepohlia rather than Cephaleuros. Thus far the genus includes three species, all new to science and so far only known from (sub-)tropical Asia.

\section{Key to species of Serusiauxiella}

1. Perithecia applanately hemispherical, erumpent and mostly covered by thallus, the exposed black ostiolar area up to $0.2 \mathrm{~mm}$ diam.; involucrellum distinctive in upper part, laterally fusing with thallus; ascospores with slightly tapering, rounded ends.

Serusiauxiella filifera

1. Perithecia hemispherical to wart-shaped or almost conical, prominent, the mostly exposed black portion up to $0.4 \mathrm{~mm}$ diam.; involucrellum confluent with excipulum in upper part; ascospores with strongly tapering, rounded to subacute ends .............................2

2. Asci $50-80 \mu \mathrm{m}$ long ...........Serusiauxiella flagellata

2. Asci $40-65 \mu \mathrm{m}$ long ............Serusiauxiella sinensis
Serusiauxiella filifera S.H. Jiang, Lücking \& J.C. Wei, sp. nov.

MycoBank: MB 833566

Fig. 8

Type: CHINA. Hainan: Dongfang City, Nanlang village E'xian Ling; $19^{\circ} 00^{\prime} 18^{\prime \prime} \mathrm{N}, 109^{\circ} 04^{\prime} 09^{\prime \prime} \mathrm{E}, 160 \mathrm{~m}$; on living leaves; 13 December 2014, J.H. Wang \& R.D. Liu HN2014362 (HMAS-L0130626).

Diagnosis: Characterized by its applanately hemispherical perithecia that are covered by thallus except for the uppermost portion, and by rather short asci.

Etymology: The epithet refers to the macroconidal appendages becoming long and filiform in squash mounts.

Description: Thallus epiphyllous, subcuticular, $2-8 \mathrm{~mm}$ across and 12-20 $\mu \mathrm{m}$ thick, sometimes growing along the nerves, margins, and scars of leaves, circular, with entire to crenulate or lobulate margins, bright green, but often becoming whitish in the center, different color shades often arranged in concentric zones, rather easily separated from leaf. Photobiont a species of Trentepohlia, cells angularrounded, 5-10 $\times 3-6 \mu \mathrm{m}$. Perithecia usually present and abundant, immersed-erumpent, applanately hemispherical, 105-120 $\mu \mathrm{m}$ high; excipulum prosoplectenchymatous, 12-20 $\mu \mathrm{m}$ thick, colorless to blackish brown; involucrellum developed only in upper part, carbonaceous, laterally fusing with thallus, $30-45 \mu \mathrm{m}$ thick; paraphyses unbranched or sparingly branched. Asci oblong, 37-53 $\times 10-12 \mu \mathrm{m}$. Ascospores biseriate or irregularly arranged, 8 per ascus, fusiform-ellipsoid, with more or less rounded ends, 1-septate, usually with 1-2 guttules in each cell when fresh and thus appearing 3 -septate, especially in $10 \% \mathrm{KOH}$, slightly constricted at the septum, usually with the distal cell somewhat enlarged, not breaking into pieces, surrounded by a thin mucilaginous sheath, $10-15 \times 2.5-5 \mu \mathrm{m}$. Pycnidia producing macroconidia $0.05-0.15 \mathrm{~mm}$, immersed-erumpent, wart-shaped, black. Macroconidia bacillar, 1-septate, $12.5-15 \times 2-3.5 \mu \mathrm{m}$, with gelatinous appendage at both ends, $13-25 \mu \mathrm{m}$ long but in squash mounts quickly growing to $70 \mu \mathrm{m}$ or more. Pycnidia producing microconidia not seen.

Chemistry: No substances detected by TLC.

Ecology and distribution: The new species grows on leaves in wet tropical forest in southern China. At present, it is known only from the type locality, but documented by numerous specimens.

Notes: This new species externally resembles Strigula microspora (Lücking 2008), from which differs chiefly by its rather applanate perithecia, short asci and biseriate ascospores. Strigula caerulensis P.M. McCarthy and S. macaronesica Sérus. also bear some resemblance, but in $S$. caerulensis the thallus is supracuticular, dull, and perithecia are rounded to subacute (McCarthy 2009b). Strigula macaronesica differs in its long linear thallus and larger ascospores (Sérusiaux 1997). 

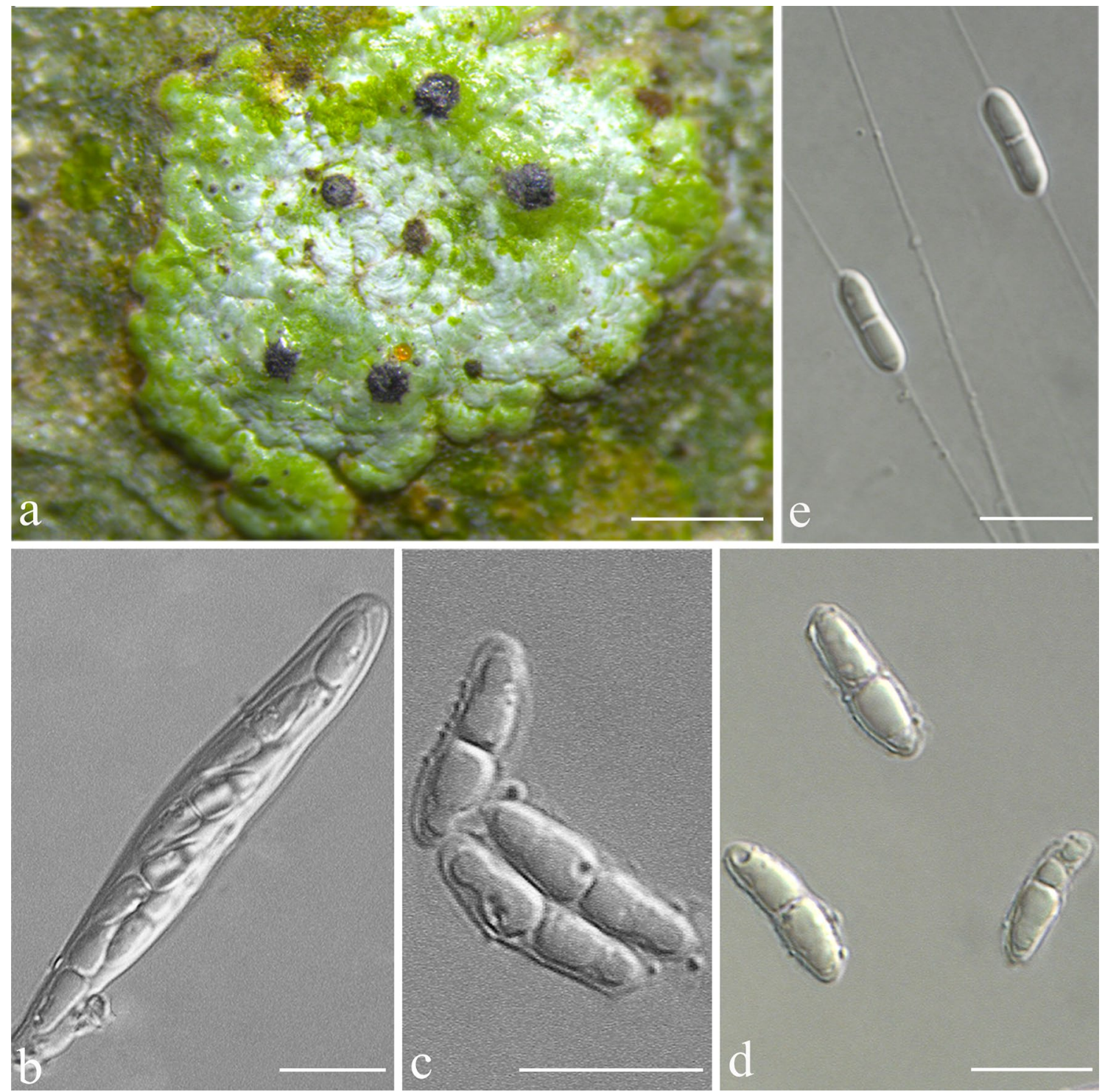

Fig. 8 Serusiauxiella filifera sp. nov. (holotype, HMAS-L0130626) a Thallus, b Asci, c, d Ascospores, e Macroconidia with extremely long appendages. Scale bars: $\mathbf{a}=600 \mu \mathrm{m}, \mathbf{b}-\mathbf{e}=10 \mu \mathrm{m}$

Additional specimens examined. CHINA. Guangxi: Nanning, Long' an County, Longhu Mountain Natural Reserve; $22^{\circ} 57^{\prime} 42^{\prime \prime} \mathrm{N}, 107^{\circ} 37^{\prime} 40^{\prime \prime} \mathrm{E}, 147 \mathrm{~m}$; on living leaves; 1 December 2015, S.H. Jiang GX201511072_1 (HMASL0141639), GX201511074_2 (HMAS-L0141640), GX201511075 (HMAS-L0139297), GX201511079 (HMAS-L0139298), GX201511081_1 (HMAS-L0141641), GX201511082_1 (HMAS-L0141642), GX201511083_1 (HMAS-L0141643), GX201511086_1 (HMAS-L0141644), GX201511088_2 (HMAS-L0141645), GX201511093 (HMAS-L0139307), GX201511096 (HMAS-L0139308), GX201511096_2 (HMAS-L0141646), GX201511097 (HMAS-L0139309), GX201511098_1 (HMAS-L0141648), GX201511107 (HMAS-L0138043), GX201511133
(HMAS-L0139311), GX201511149 (HMAS-L0139313), GX201511153 (HMAS-L0139315). Longzhou County, Nonggang National Nature Reserve; $22^{\circ} 27^{\prime} 55^{\prime \prime} \mathrm{N}, 106^{\circ}$ 57' 5" E, 270 m; on living leaves; 3 December 2015, S.H. Jiang, GX201511199 (HMAS-L0139219), GX201511199_2 (HMAS-L0141651), GX201511209 (HMAS-L0139223), GX201511209_2 (HMAS-L0141652), GX201511210_2 (HMAS-L0141653), GX201511225 (HMAS-L0139288), GX201511227 (HMAS-L0139290), GX201511250_2 (HMAS-L0141655), GX201511259 (HMAS-L0139234), GX201511265_1 (HMAS-L0141656), GX201511265_2 (HMAS-L0141657), GX201511282_1 (HMAS-L0141660), GX201511281_3 (HMAS-L0141659), GX201511283 (HMAS-L0139323), GX201511317_2 (HMAS-L0141666), 
GX201511319 (HMAS-L0139325); ibid., 22 ${ }^{\circ} 59^{\prime} 15^{\prime \prime} \mathrm{N}$, $106^{\circ} 56^{\prime} 45^{\prime \prime}$ E, $268 \mathrm{~m}$; on living leaves; 24 May 2015, X.L. Wei \& J.H. Wang GX20150187 (HMAS-L0139270), GX20150193 (HMAS-L0139272), GX20150193_2 (HMAS-L0141579). Hainan, Dongfang City, Nanlang village E'xian Ling; $19^{\circ} 00^{\prime} 18^{\prime \prime} \mathrm{N}, 109^{\circ} 04^{\prime} 09^{\prime \prime} \mathrm{E}, 160 \mathrm{~m}$; on living leaves; 13 December 2014, J.H. Wang \& R.D. Liu HN2014358 (HMAS-L0130625), HN2014373 (HMASL0130627), HN2014375 (HMAS-L0130629).

Serusiauxiella flagellata S.H. Jiang, Lücking \& J.C. Wei, sp. nov.

MycoBank: MB 833568

Fig. 9

Type: CHINA. Hainan: Ledong County, Jianfengling; $18^{\circ} 44^{\prime} 36^{\prime \prime} \mathrm{N}, 108^{\circ} 50^{\prime} 39^{\prime \prime} \mathrm{E}, 962 \mathrm{~m}$; on living leaves; 12 December 2014, J.H. Wang \& R.D. Liu HN20144632 (HMAS-L0139216).

Diagnosis: This species is most closely related to Ser. sinensis, from which it differs by its longer asci and in the following positions in the ITS (Suppl. File S1): [substitutions] A-G (143), C-T (49, 79, 81, 99, 124, 308, 316, 318, 361), G-C (314), T-C (17, 78, 87, 92, 105, 349); [indels] $(80,135)$.

Etymology: The epithet refers to the macroconidial appendages resembling flagellae.

Description: Thallus epiphyllous, subcuticular, 3-10 mm across and 15-30 $\mu \mathrm{m}$ thick, generally growing along the nerves, margins, and scars of leaves, circular, with entire to crenulate or lobulate margins, bright green, often becoming pale bluish-grey to whitish in the center. Photobiont a species of Trentepohlia, cells angular-rounded, 5-10×3-6 $\mu \mathrm{m}$. Perithecia hemispherical to wart-shaped, basally immersed but for the most part exposed, $0.3-0.4 \mathrm{~mm}$ diam. and $80-170 \mu \mathrm{m}$ high; excipulum prosoplectenchymatous, 5-10 $\mu \mathrm{m}$ thick, colorless to blackish brown; involucrellum carbonized, 10-20 $\mu \mathrm{m}$ thick, black; paraphyses unbranched or sparingly branched. Asci oblong, 50-80×7-10 $\mu \mathrm{m}$. Ascospores biseriate, 8 per ascus, fusiform, with tapering, rounded to subacute ends, 1-septate, usually with 1-2 guttules in each cell, not breaking into pieces, surrounded by a thin mucilaginous sheath, $12-18 \times 3-5 \mu \mathrm{m}$. Pycnidia producing macroconidia immersed-erumpent, wart-shaped, $0.1-0.15 \mathrm{~mm}$, black. Macroconidia bacillar, 1-septate, $10-13 \times 2.5-3.7 \mu \mathrm{m}$, with gelatinous appendages at both ends, $13-25 \mu \mathrm{m}$ long but in squash mounts quickly growing to $70 \mu \mathrm{m}$ or more. Pycnidia producing microconidia not seen.

Chemistry: No substances detected by TLC.

Ecology and distribution: Serusiauxiella flagellata is known through a number of collections from around the type locality in South China. It grows on leaves in wet tropic forest.

Notes: Serusiauxiella flagellata differs from Ser. filifera in the distinctly more exposed, hemispherical to wart-shaped perithecia and the ascospores with more distinctly tapering ends. Phylogenetically, the two species differ in numerous substitutions in the ITS (see above).

Additional specimens examined: CHINA. Hainan: Ledong County, Jianfengling; 18 44' 36" N, 108 50' 39" E, 962 m; on living leaves; 12 December 2014, J.H. Wang \& R.D. Liu HN2014240_4 (HMAS-L0141609); ibid.; $18^{\circ} 44^{\prime} 5^{\prime \prime} \mathrm{N}$, $108^{\circ} 52^{\prime}$ 8" E, $920 \mathrm{~m}$; on living leaves; 11 December 2014, J.H. Wang \& R.D. Liu HN2014131 (HMAS-L0130554).

Serusiauxiella sinensis S.H. Jiang, Lücking \& J.C. Wei, sp. nov. MycoBank: MB 833570

Fig. 10

Type: CHINA. Hainan: Ledong County, Jianfengling, Mingfenggu; $18^{\circ} 44^{\prime} 32^{\prime \prime} \mathrm{N}, 108^{\circ} 50^{\prime} 32^{\prime \prime} \mathrm{E}, 985 \mathrm{~m}$; on living leaves; 12 December 2014, J.H. Wang \& R.D. Liu HN2014281_2 (HMAS-L0141614).

Diagnosis: Differing from Serusiauxialla flagellata chiefly in its shorter asci and in the following positions in the ITS (Suppl. File S1): [substitutions] C-G (314), C-T (17, $78,87,92,105,349)$, G-A (143), T-C (49, 79, 81, 99, 124 , 308, 316, 318, 361), [indels] $(80,135)$.

Etymology: The epithet refers to the discovery of this new species in China.

Description: Thallus epiphyllous, subcuticular, 3-10 $\mathrm{mm}$ across and 10-20 $\mu \mathrm{m}$ thick, typically growing along the nerves, margins, and scars of leaves, circular, with entire to crenulate or lobulate margins, bright green but sometimes becoming whitish in the center. Photobiont a species of Trentepohlia, cells angular-rounded, $5-10 \times 3-6 \mu \mathrm{m}$. Perithecia mostly erumpent, hemispherical to wart-shaped, $0.2-0.3 \mathrm{~mm}$ diam. and $100-180 \mu \mathrm{m}$ high, exposed part black; excipulum prosoplectenchymatous, 5-10 $\mu \mathrm{m}$ thick, colorless to blackish brown; involucrellum carbonized, 10-30 $\mu \mathrm{m}$ thick, black; paraphyses unbranched or sparingly branched. Asci oblong, 40-65 $\times 5-10 \mu \mathrm{m}$. Ascospores biseriate or irregularly arranged, 8 per ascus, fusiform, with tapering, rounded to subacute ends, 1-septate, slightly constricted at the septum, not breaking into pieces, surrounded by a thin mucilaginous sheath, $10-18 \times 3.5-5 \mu \mathrm{m}$. Pycnidia immersed-erumpent, wartshaped, those producing macroconidia $0.1-0.15 \mathrm{~mm}$, those producing microconidia $0.05-0.1 \mathrm{~mm}$ diam., black. Macroconidia bacillar, 1-septate, $12-15 \times 2-3.5 \mu \mathrm{m}$, with gelatinous appendages at both ends, $13-25 \mu \mathrm{m}$ long but in squash mounts quickly growing to $70 \mu \mathrm{m}$ or more. Microconidia fusiform, non-septate, $3-4 \times 1-1.5 \mu \mathrm{m}$.

Chemistry: No substances detected by TLC.

Ecology and distribution: This species is known from several collections from the type locality and its vicinity in South China. It grows on leaves in wet tropic forest. 

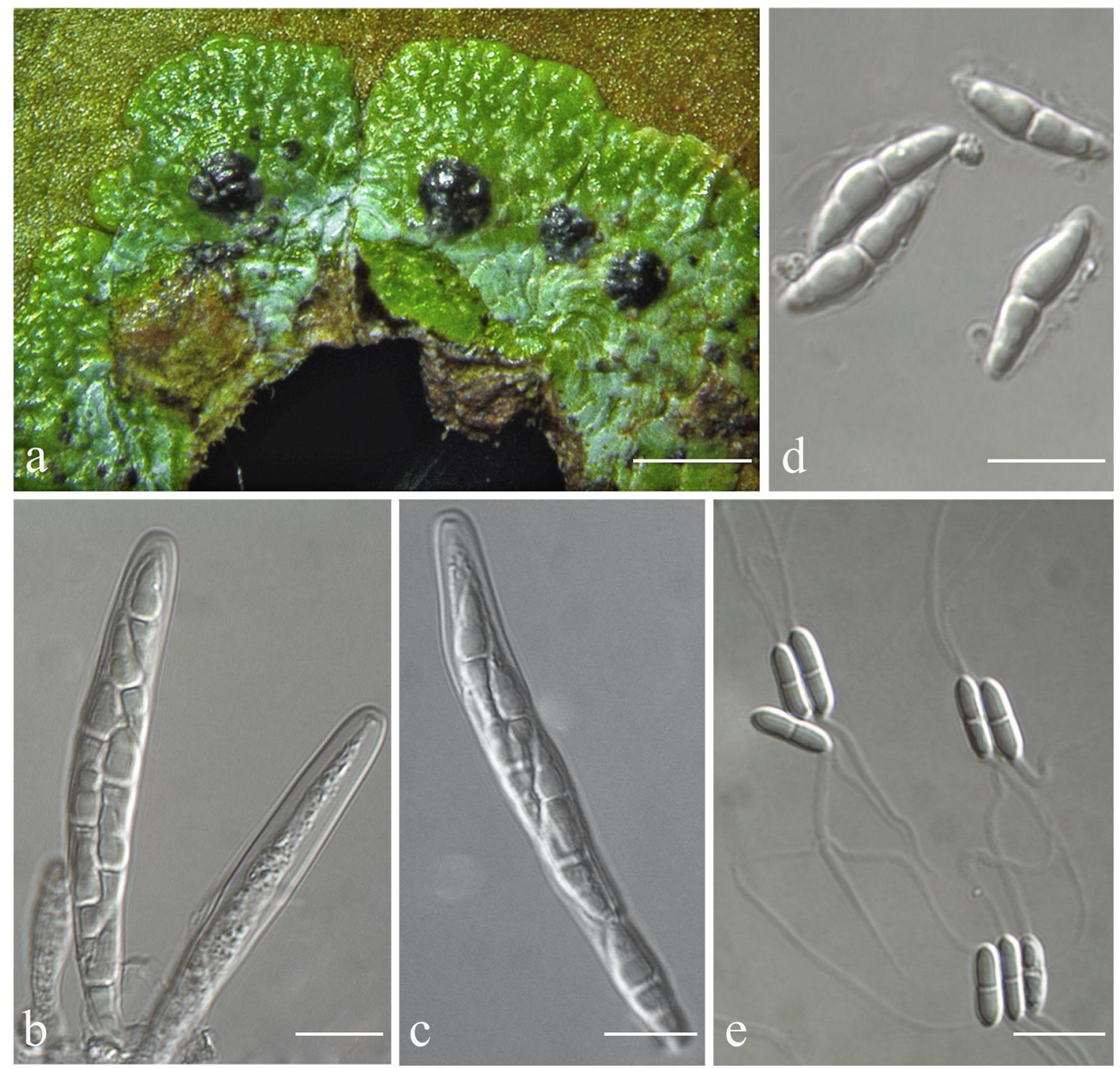

Fig. 9 Serusiauxiella flagellata sp. nov. (holotype, HMAS-L0139216) a Thallus b-c Asci d Ascospores e Macroconidia with long appendages. Scale bars: $\mathbf{a}=600 \mu \mathrm{m}, \mathbf{b}-\mathbf{e}=10 \mu \mathrm{m}$

Notes: This new species is very similar to Serusiauxiella filifera and the only tangible difference appears to be the shorter asci. The differences in the ITS are, however, substantial, with an overall similarity of only $95.6 \%$ (see above).

Additional specimens examined. CHINA. Hainan, Ledong County, Jianfengling, Mingfenggu; $18^{\circ} 44^{\prime} 32^{\prime \prime} \mathrm{N}, 108^{\circ} 50^{\prime}$ 32" E, $985 \mathrm{~m}$; on living leaves; 12 December 2014, J.H. Wang \& R.D. Liu HN2014287 (HMAS-L0130616); ibid., $18^{\circ} 44^{\prime} 5^{\prime \prime} \mathrm{N}, 108^{\circ} 52^{\prime} 8^{\prime \prime} \mathrm{E}, 920 \mathrm{~m}$; on living leaves; 11 December 2014, J.H. Wang \& R.D. Liu HN2014191_3 (HMAS-L0141611), HN2014191_4 (HMAS-L0141612); ibid., $18^{\circ} 44^{\prime} 36^{\prime \prime} \mathrm{N}, 108^{\circ} 50^{\prime} 39^{\prime \prime} \mathrm{E}, 962 \mathrm{~m}$; on living leaves; 12 December 2014, J.H. Wang \& R.D. Liu HN2014231_7 (HMAS-L0141605).
3. Raciborskiella Höhn., Sber. Akad. Wiss. Wien, Math.Naturw. Kl., Abt. 1 118: 1176 (1909).

\section{MycoBank: MB 4636}

Type species: Raciborskiella talaumae (Racib.) Höhn.

Description: Thallus foliicolous, subcuticular, hypophyllous, dispersed into rounded, partly confluent patches with entire margins, very thin, usually dark bluish grey. Photobiont Cephaleuros. Perithecia fully exposed, prominent, more or less conical, not covered by thallus, black; excipulum prosoplectenchymatous, colorless; involucrellum carbonized, black; hamathecium colorless, I-, KI-; paraphyses slightly branched and anastomosing. Asci bitunicate, with short tholus and narrow ocular chamber, I-, KI-, clavate to oblong. Ascospores 8 per ascus, biseriate to irregular arranged, fusiform, 1-septate, colorless, rather large, 

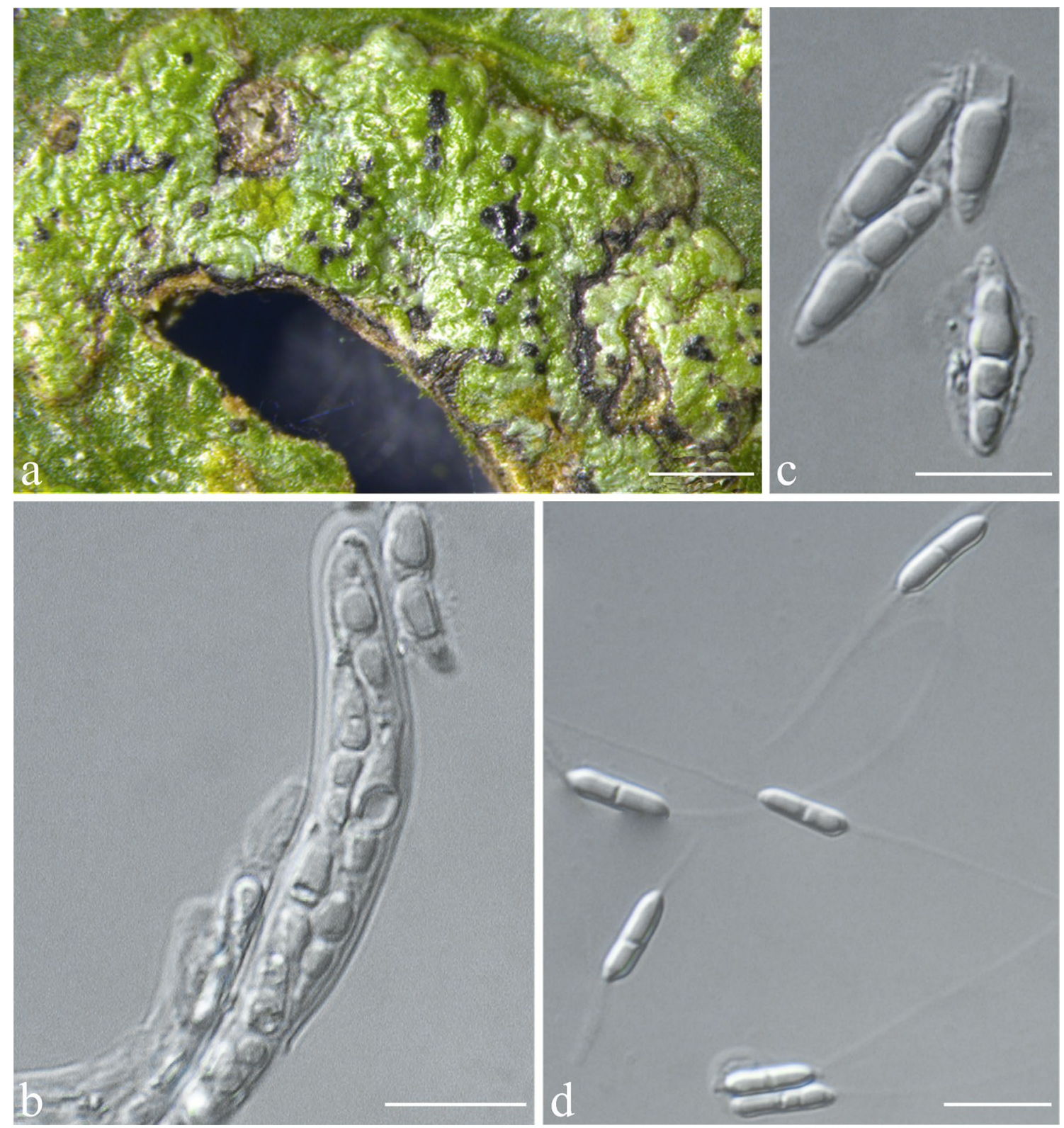

Fig. 10 Serusiauxiella sinensis sp. nov. (holotype, HMAS-L0141614) a Thallus, b Asci, c Ascospores, d Macroconidia showing the long-grown appendages. Scale bars: $\mathbf{a}=600 \mu \mathrm{m}, \mathbf{b}-\mathbf{d}=10 \mu \mathrm{m}$

$30-70 \times 5-7 \mu \mathrm{m}$, strongly constricted at the septum and frequently breaking into part spores, both ends sometimes with thin, gelatinous appendages. Pycnidia adnate, wart-shaped to conical, black. Macroconidia bacillar to filiform, 1-septate, colorless, both ends with short to medium-sized, gelatinous appendages (not exceeding $50 \mu \mathrm{m}$ even after prolonged time in squash mounts). Microconidia fusiform-ellipsoid, nonseptate, colorless.

Chemistry: No substances detected by TLC.

Notes: Raciborskiella was kept as a separate genus by Santesson (1952) and various subsequent workers (Singh 1970; Vézda 1984; Roux and Sérusiaux 1995; Sérusiaux and Polly 1996), with two species growing hypophyllous. This classification was not accepted in more recent treatments, which subsumed Raciborskiella within Strigula s.lat. (Harris 1995; Lücking 2008; McCarthy 2009a). Our data show that the two species previously included in this genus by Santesson (1952) are not closely related, with Strigula prasina clustering within Strigula s.str. This is in accordance with substantial anatomical differences between the two taxa (Santesson 1952; Lücking 2008). On the other hand, $R$. janeirensis sensu Santesson (1952) corresponds to two phylogenetically distinct species, differing in ascospore size, $R$. janeirensis s.str. and $R$. talaumae, the type of the genus. 
On account of the phylogenetic analysis and the unique morpho-anatomical characters (very thin, bluish grey thallus, branched and anastomosing paraphyses, large and strongly constricted ascospores sometimes with thin appendages; see also Roux and Sérusiaux 1995), the genus Raciborskiella is here resurrected, but its hypophyllous growth is not a diagnostic feature. Except for Raciborskiella s.str., ascospore appendages have so far only been reported from one species currently placed in Strigula s.str., S. kaitokensis Sérusiaux \& Polly, but are definitely absent in most species of Strigula s.str. and the other foliicolous genera distinguished here (see also Sérusiaux and Polly 1996).

\section{Key to species of Raciborskiella}

1. Ascospores 30-40 $\mu \mathrm{m}$ long; paleotropical Raciborskiella talaumae

1. Ascospores 40-70 $\mu \mathrm{m}$ long; chiefly neotropical Raciborskiella janeirensis

Raciborskiella talaumae (Racib.) Höhn., Sber. Akad. Wiss. Wien, Math.-Naturw. Kl., Abt. 1118 : 1176 (1909).

Fig. 11

Basionym: Clypeolum talaumae Racib., Parasit. Alg. Pilze Java's (Jakarta) 3: 35 (1900).

Type: INDONESIA. Java: Goenoeng Pantjar; Raciborski s.n. (holotype, KRA, not seen).

Description. Thallus subcuticular, hypophyllous, dispersed into rounded to partly confluent patches, often occurring along the leaf nerves and margins, $2-15 \mathrm{~mm}$ across and $7-15 \mu \mathrm{m}$ thick, dark grey-green to bluish grey. Photobiont a species of Cephaleuros, cells 7-12 $\times 5-10 \mu \mathrm{m}$. Perithecia completely exposed, prominent, wart-shaped to conical, $0.3-0.6 \mathrm{~mm}$ diam and $60-150 \mu \mathrm{m}$ high, black; excipulum prosoplectenchymatous, $12-18 \mu \mathrm{m}$ thick, colorless to brown; involucrellum carbonized, $12-20 \mu \mathrm{m}$ thick, black; paraphyses slightly branched and anastomosing. Asci oblong, 90-105 $\times 12-15 \mu \mathrm{m}$. Ascospores biseriate to irregularly arranged, oblong to fusiform, 1-septate, 30-40×5-7 $\mu \mathrm{m}$, with strong constriction at the septum and usually breaking into parts within the asci, both ends sometimes with thin, terminal gelatinous appendages. Pycnidia wart-shaped, those producing macroconidia $0.15-0.2 \mathrm{~mm}$, those producing microconidia $0.05-0.1 \mathrm{~mm}$, black. Macroconidia bacillar, 1-septate, $10-13 \times 2.5-5 \mu \mathrm{m}$. Microconidia fusiform, non-septate, $3-5 \times 1 \mu \mathrm{m}$.

Chemistry: No substances detected by TLC.

Distribution and ecology: This species is apparently eastern paleotropical, known from the type from Indonesia (Java) and from mainland China, there found in humid, semiexposed forest habitats.

Notes: Raciborskiella talaumae differs from $R$. janeirensis in ascospore size, those of the latter being $40-70 \mu \mathrm{m}$ long. Santesson (1952) considered the ascospore measurements of $R$. talaumae to refer to young ascospores, but our material and the molecular data clearly set the two species apart. Melanopsamma areolatum Rehm from Brazil was also described as having shorter ascospores $(30-36 \mu \mathrm{m})$, but Santesson annotated the type as having $35-52 \mu \mathrm{m}$ long ascospores, thus in the range of $R$. janeirensis and a synonym of the latter.

Specimens examined. CHINA. Hainan: Baoting County, Qixianling National Nature Reserve; $18^{\circ} 42^{\prime} 21^{\prime \prime} \mathrm{N}, 109^{\circ}$ 42' 14" E, 350 m; on living leaves; 7 September 2017, S.H. Jiang HN20171643 (HMAS-L0139627), HN20171510 (HMAS-L0139628), HN20171246 (HMAS-L0139624), HN20171534 (HMAS-L0139629), HN20171523 (HMASL0139626), HN20171258 (HMAS-L0139625).

4. Puiggariella Speg., Anal. Soc. Cient. Argent. 12(3): 99 (1881).

\section{MycoBank: MB 4546}

Type species: Puiggariella apiahyna Speg. [= Puiggariella nemathora (Mont.) S.H. Jiang, Lücking \& J.C. Wei].

Description: Thallus foliicolous, subcuticular, with entire margins or crenulate-lobulate to laciniate, lobes widely separated to completely confluent, surface usually with numerous minute, white papillae. Photobiont Cephaleuros. Perithecia immersed-erumpent to prominent, wart-shaped to applanately conical, often ridged or fissured; excipulum prosoplectenchymatous, colorless; involucrellum colorless to pale brown, not carbonized; hamathecium colorless, I-, KI-; paraphyses unbranched, thin. Asci bitunicate, with short tholus and narrow, ocular chamber, I-, KI-, clavate to oblong. Ascospores 8 per ascus, uniseriate to biseriate, fusiform, 1-septate, colorless, 15-25×4-6 $\mu \mathrm{m}$. Pycnidia immersed-erumpent, wart-shaped to conical, pale to brownish. Macroconidia bacillar to filiform, 1-septate, colorless, both ends usually with short to medium length gelatinous appendages (usually not exceeding $40 \mu \mathrm{m}$ even after prolonged time in squash mounts). Microconidia fusiformellipsoid, non-septate, colorless.

Chemistry: No substances detected by TLC.

Notes: The species included in this small genus are quite characteristic due to their thallus morphology (often laciniate and with white papillae) and the uncarbonized perithecia which often feature ridges or fissures. Spegazzini (1881) did not recognize the distinctiveness of this lineage, nor did he realize that he dealt with a lichenized fungus, and Santesson (1952) included what he believed to be a single species within Strigula. Based on our data, we currently distinguish three species. 

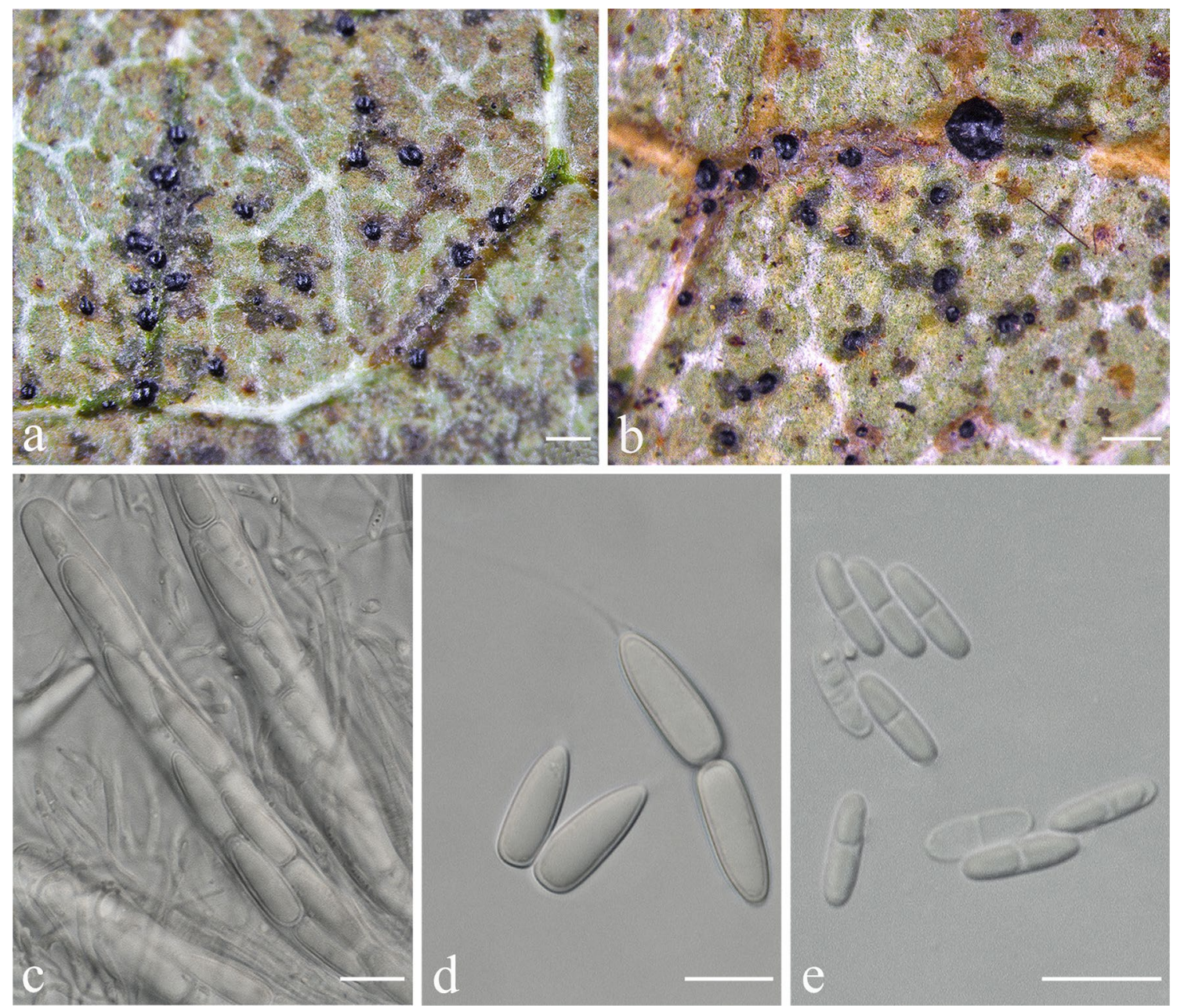

Fig. 11 Raciborskiella talaumae a Thallus (HMAS-L0139627), b Thallus (HMAS-L0139628), c Asci (HMAS-L0139627),, d Ascospores (HMAS-L0139627), e Macroconidia (HMAS-L0139628). Scale bars: $\mathbf{a}, \mathbf{b}=500 \mu \mathrm{m}, \mathbf{c}, \mathbf{e}=10 \mu \mathrm{m}$

\section{Key to species of Puiggariella}

1. Thallus lobes indistinct and irregular, only visible marginally, otherwise the thallus appearing mostly entire; surface with scattered, minute papillae ..............

\section{Puiggariella confluens}

1. Thallus lobes distinct, becoming laciniate and in part leaving interspaces, irregular to regularly radiating; lobe margins with numerous, minute papillae ............. 2

2. Thallus lobes regularly radiating, slightly separate to contiguous .................. Puiggariella nigrocincta

2. Thallus lobes irregular, often widely spaced Puiggariella nemathora

Puiggariella confluens (Müll. Arg.) S.H. Jiang, Lücking \& J.C. Wei, comb. et stat. nov.

Fig. 12

MycoBank: MB 833575

Basionym: Strigula argyronema var. confluens Müll. Arg., Bull. Soc. R. Bot. Belg. 30(1): 88 (1891).
Type: COSTA RICA. Alajuela: Môle de San Rafael; 1899; H. Pittier 5162 (holotype, G-G00292244!)

Description. Thallus subcuticular, lobulate-crenulate, with short, rounded, confluent lobes, 4-15 $\mathrm{mm}$ across and 30-50 $\mu \mathrm{m}$ thick, surface usually with numerous minute, white papillae. Photobiont a species of Cephaleuros, cells $8-13 \times 4-7 \mu \mathrm{m}$. Perithecia erumpent to prominent, covered by a thick thallus layer up to ostiole, wartshaped, $0.5-0.9 \mathrm{~mm}$ diam. and 100-250 $\mu \mathrm{m}$ high, pale greenish grey to white, ridged; excipulum prosoplectenchymatous, $12-25 \mu \mathrm{m}$ thick, colorless; involucrellum confluent with excipulum, 35-75 $\mu \mathrm{m}$ thick, colorless to pale brown; paraphyses unbranched. Asci oblong, 75-110 $\times 7.5-10 \mu \mathrm{m}$. Ascospores uniseriate, fusiform, 1-septate, with constriction at septum, 17-20×4-5 $\mu \mathrm{m}$. Pycnidia producing macroconidia immersed-erumpent, wart-shaped, 0.1-0.15 mm, black. Macroconidia bacillar, 1-septate, $10-13 \times 2.5-3.7 \mu \mathrm{m}$, with appendages at both 
ends $15-30 \mu \mathrm{m}$ long. Pycnidia producing microconidia not seen.

Chemistry: No substances detected by TLC.

Notes. This taxon is here elevated to species level, as it differs from typical Puiggariella nemathora in the marginally confluent lobes.

Additional specimens examined. COSTA RICA. Cartago: Orosi valley; $09^{\circ} 47^{\prime} \mathrm{N}, 83^{\circ} 51^{\prime} \mathrm{W}, 1150 \mathrm{~m}$; coffee plantations and secondary vegetation, on leaves; 1991, R. Lücking 6a-2 (B-600205073), 6a-3 (B600205074). GUATEMALA. Izabal: Quiriguá; $15^{\circ} 16^{\prime} 10^{\prime \prime} \mathrm{N}, 89^{\circ} 02^{\prime} 25^{\prime \prime} \mathrm{W}$, $75 \mathrm{~m}$; secondary vegetation around Maya archaeological site, on leaves; December 1991, R. Lücking 4524 (B-600205040).
Puiggariella nemathora (Mont.) S.H. Jiang, Lücking \& J.C. Wei, comb. nov.

MycoBank: MB 833579

Fig. 13

Basionym: Strigula nemathora Mont. in Sagra, Historia Física, Política y Natural de la Isla de Cuba 9: 96 (1845).

Type: CUBA. Unknown locality; Auber s.n. or de la Sagra s.n. (holotype, PC!).

Description. Thallus subcuticular, lobulate, with elongate to laciniate, usually diverging lobes leaving interspaces, $5-30 \mathrm{~mm}$ across and $30-50 \mu \mathrm{m}$ thick, lobe margins with numerous minute, white papillae. Photobiont a species of Cephaleuros, cells 8-14×4-7 $\mu \mathrm{m}$. Perithecia erumpent to prominent, covered by a thick thallus layer up to ostiole, wart-shaped, 0.5-1 mm diam. and 150-250 $\mu \mathrm{m}$ high, pale greenish grey to white, ridged; excipulum
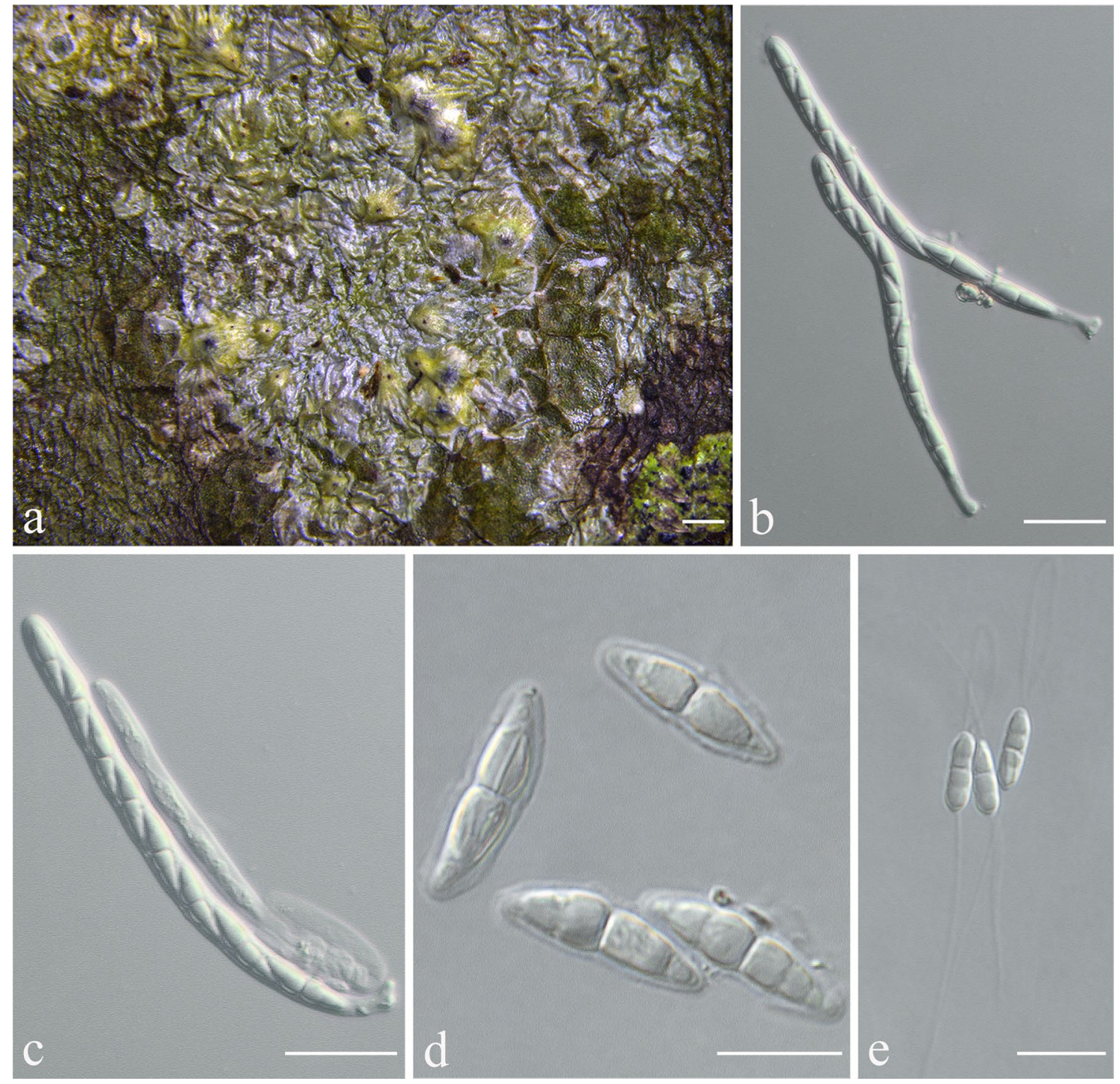

Fig. 12 Puiggariella confluens comb. nov. (B-600205074) a Thallus, b-c Asci, d Ascospores, e Macroconida. Scale bars: $\mathbf{a}=500 \mu \mathrm{m}$, b, $\mathbf{c}=20 \mu \mathrm{m}, \mathbf{d}-\mathbf{e}=10 \mu \mathrm{m}$ 
prosoplectenchymatous, $12-25 \mu \mathrm{m}$ thick, colorless; involucrellum confluent with excipulum, 30-70 $\mu \mathrm{m}$ thick, colorless to pale brown; paraphyses unbranched. Asci oblong, $80-110 \times 7-10 \mu \mathrm{m}$. Ascospores uniseriate to irregularly arranged, fusiform, 1-septate, with constriction at septum, 17-22 $\times 4-6 \mu \mathrm{m}$. Pycnidia producing macroconidia immersed-erumpent, wart-shaped, $0.1-0.15 \mathrm{~mm}$, black. Macroconidia bacillar, 1-septate, 9-13×2.5-3.5 $\mu \mathrm{m}$, with appendages at both ends $15-30 \mu \mathrm{m}$ long. Microconidia fusiform, non-septate, $3-5 \times 1.3-1.7 \mu \mathrm{m}$.

Chemistry: No substances detected by TLC.

Distribution and ecology: The distribution of Strigula nemathora is difficult to ascertain, but it may deal with a neotropical taxon, as this morphotype is mostly known from that region.
Notes: The name Strigula nemathora is here restricted to a taxon with distinctly laciniate, often widely spaced lobes, a frequent morphotype commonly found in the Neotropics (Lücking 2008). More data are required to disentangle this species complex and evaluate the status of the various synonyms of $S$. nemathora proposed by Santesson (1952).

Additional specimens examined. BRAZIL. Paraiba: Mamanguape, Reserva Biológica Guaribas; 06 44' 59" S, $41^{\circ} 07^{\prime} 11^{\prime \prime} \mathrm{W}, 204 \mathrm{~m}$; Atlantic forest, on leaves; October 2014, A.B. Xavier-Leite 1586 (ISE-32586). Sergipe: Itabaiana, Parque Nacional Serra de Itabaiana; $10^{\circ} 42^{\prime} 36^{\prime \prime} \mathrm{S}$, $37^{\circ} 16^{\prime} 42^{\prime \prime} \mathrm{W}, 400-660 \mathrm{~m}$; Atlantic forest, on leaves; A.B. Xavier-Leite 1794 (ISE-32794).
Fig. 13 Puiggariella nemathora comb. nov. (ISE-32794) a Thallus, b, c Asci and ascospores, d Macroconida. Scale bars: $\mathbf{a}=2 \mathrm{~mm}, \mathbf{b}-\mathbf{d}=10 \mu \mathrm{m}$
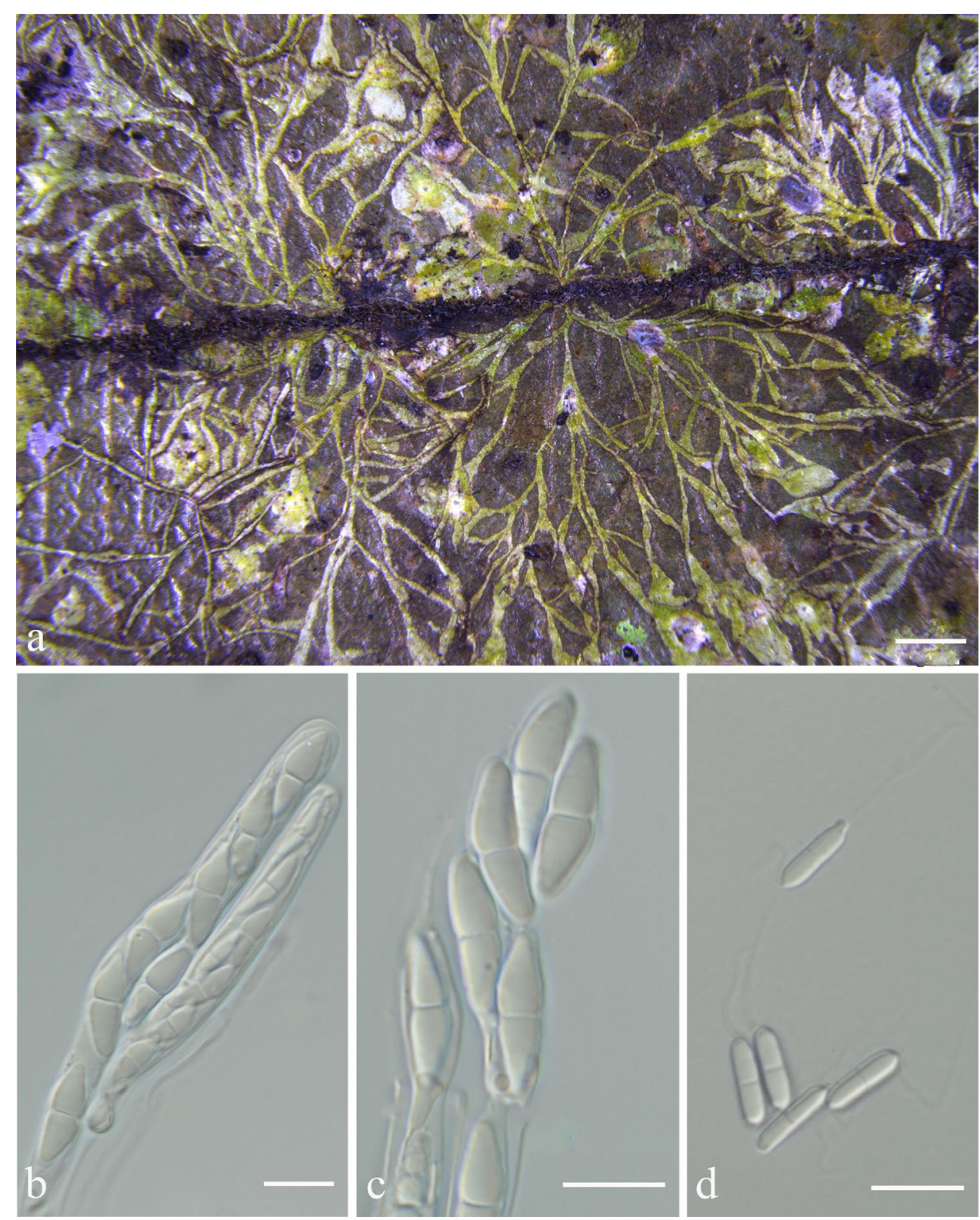
Puiggariella nigrocincta (Müll. Arg.) S.H. Jiang, Lücking \& J.C. Wei, comb. nov.

Fig. 14

MycoBank: MB 833581

Basionym: Strigula nigrocincta Müll. Arg., Hedwigia 30: 187 (1891).

Type: VIETNAM. “Tonkin”, Mont Ba Vi; 1889, B. Balansa 3 (holotype, G-G00292245!).

Description. Thallus subcuticular, lobulate, with elongate to laciniate, separate to confluent, regularly radiating lobes, 5-15 $\mathrm{mm}$ across and 30-50 $\mu \mathrm{m}$ thick, lobe margins with numerous minute, white papillae. Photobiont a species of Cephaleuros, cells $8-15 \times 5-8 \mu \mathrm{m}$. Perithecia erumpent to prominent, covered by a thick thallus layer up to ostiole, wart-shaped, 0.3-0.6 mm diam. and 150-200 $\mu \mathrm{m}$ high, pale greenish grey to white, ridged; excipulum prosoplectenchymatous, $15-25 \mu \mathrm{m}$ thick, colorless; involucrellum confluent with excipulum, $30-50 \mu \mathrm{m}$ thick, colorless to pale brown; paraphyses unbranched. Asci oblong, 80-100×7-10 $\mu \mathrm{m}$. Ascospores irregularly biseriate, fusiform, 1-septate, with constriction at septum, 17-22×4-6 $\mu \mathrm{m}$. Pycnidia producing macroconidia immersed-erumpent, wart-shaped, 0.1-0.15 mm, black. Macroconidia bacillar, 1-septate,
9-13 $\times 2.5-3.5 \mu \mathrm{m}$, with appendages at both ends $15-30 \mu \mathrm{m}$ long. Microconidia fusiform, non-septate, $3-5 \times 1.3-1.7 \mu \mathrm{m}$.

Chemistry: No substances detected by TLC.

Distribution and ecology: This is likely an eastern pantropical species, thus far known from Vietnam and (sub-) tropical southern China.

Notes: Based on our molecular data, Strigula nemathora s.lat. as defined by Santesson (1952) comprises more than one species. The two sequenced clades differ in thallus morphology and distribution. We have therefore restricted the name $S$. nemathora to the neotropical material with typically separate, somewhat irregular laciniae and take up the name S. nigrocincta for the eastern paleotropical material with radiating, more contiguous lobes. The material from China is quite uniform in this respect and agrees well with the type from China. The epithet nigrocincta is a bit misleading, as it refers to the blackened area of the leaf around the thalli. This effect is likely phorophyte-specific and not a feature of the lichen.

Additional specimens examined. CHINA. Guangxi: Longzhou County, Nonggang National Nature Reserve; $22^{\circ} 27^{\prime}$ $55^{\prime \prime} \mathrm{N}, 106^{\circ} 57^{\prime} 5^{\prime \prime} \mathrm{E}, 270 \mathrm{~m}$; on living leaves; 3 December
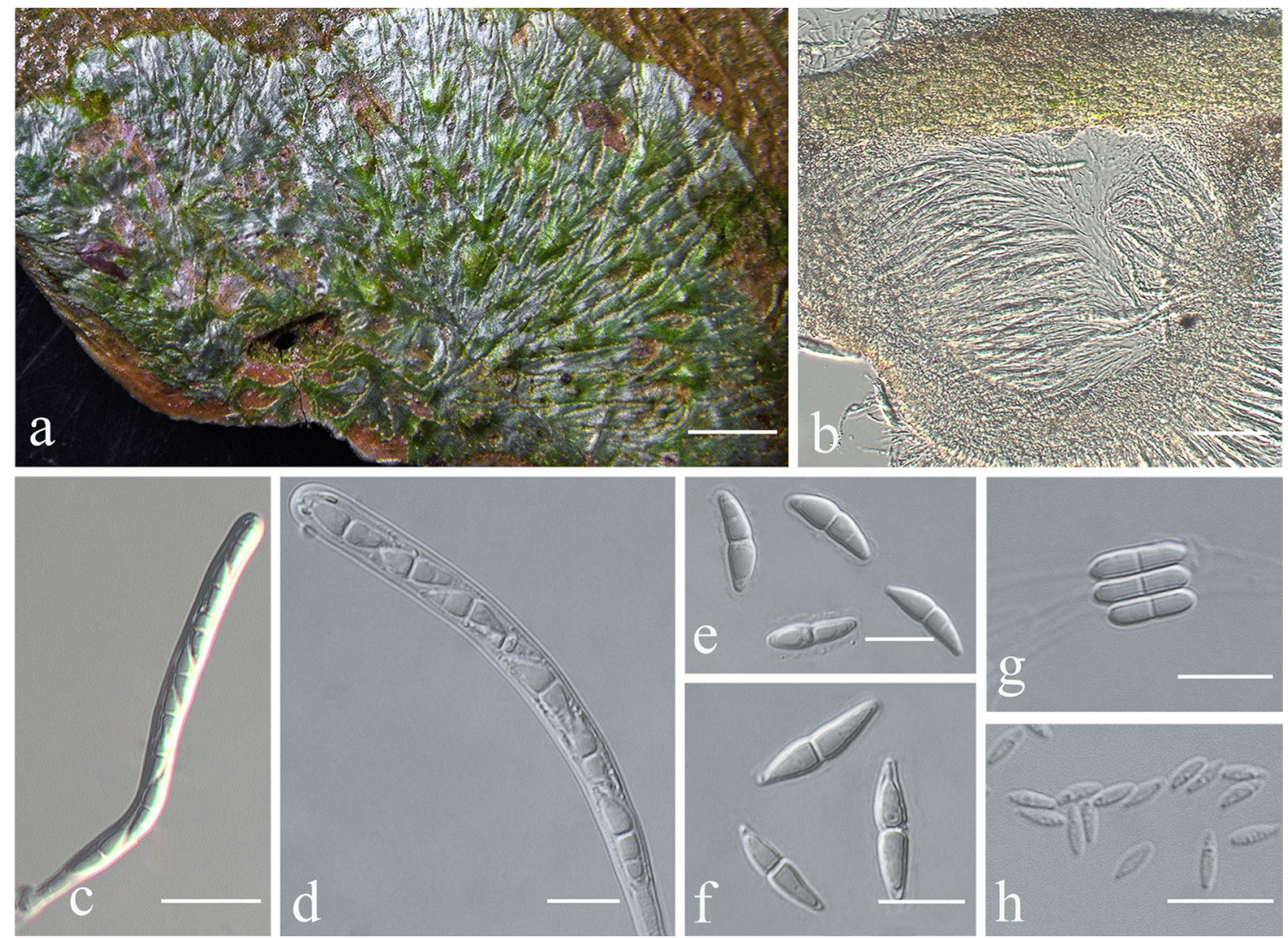

Fig. 14 Puiggariella nigrocincta comb. nov. a Thallus (HMASL0141549), b Perithecia (HMAS-L0141533), c, d Asci (HMASL0141533), e, f Ascospores (HMAS-L0141533), g Macroconidia
(HMAS-L0141544), h Microconidia (HMAS-L0141544). Scale bars: $\mathbf{a}=500 \mu \mathrm{m}, \mathbf{b}=50 \mu \mathrm{m}, \mathbf{c}=20 \mu \mathrm{m}, \mathbf{d}-\mathbf{h}=10 \mu \mathrm{m}$ 
2015, S.H. Jiang, GX201511241 (HMAS-L0139287), GX201511249 (HMAS-L0139231), GX201511252 (HMAS-L0139232). Yunnan: Xishuangbanna, Mengla County, tropical botanical garden of Chinese Academy of Sciences, East area; $21^{\circ} 55^{\prime} 39^{\prime \prime} \mathrm{N}, 101^{\circ} 15^{\prime} 52^{\prime \prime} \mathrm{E}, 560 \mathrm{~m}$; on living leaves; 18 November 2015, X.L. Wei \& S.H. Jiang XTBG2015005 (HMAS-L0139341), XTBG2015008 (HMAS-L0139385), XTBG2015011_1 (HMAS-L0139332), XTBG2015011_2 (HMAS-L0141530), XTBG2015024_1 (HMAS-L0139348), XTBG2015024_3 (HMAS-L0141532), XTBG2015024_4 (HMAS-L0141533), XTBG2015025_2 (HMAS-L0139334), XTBG2015028 (HMAS-L0139335), XTBG2015029_2 (HMAS-L0141534), XTBG2015030_1 (HMAS-L0139350), XTBG2015030_2 (HMAS-L0141535), XTBG2015030_3 (HMAS-L0141536), XTBG2015038_1 (HMAS-L0141537), XTBG2015042 (HMAS-L0139336), XTBG2015044 (HMAS-L0139356), XTBG2015050_1 (HMAS-L0139360), XTBG2015050_2 (HMAS-L0141539), XTBG2015059_1 (HMAS-L0139363), XTBG2015059_4 (HMAS-L0141540), XTBG2015059_5 (HMAS-L0141541), XTBG2015059_6 (HMAS-L0141542), XTBG2015059_7 (HMAS-L0141543), XTBG2015059_8 (HMAS-L0141544), XTBG2015059_9(HMAS-L0141545), XTBG2015059_10 (HMAS-L0141546), XTBG2015061_2 (HMAS-L0139396), XTBG2015061_3 (HMAS-L0141547), XTBG2015061_4 (HMAS-L0141548), XTBG2015064 (HMAS-L0139366), XTBG2015064_3 (HMAS-L0141549), XTBG2015064_4 (HMAS-L0141550), XTBG2015065_5 (HMAS-L0141552), XTBG2015065_6 (HMAS-L0141553), XTBG2015065_7 (HMAS-L0141554), XTBG2015065_8 (HMAS-L0141555), XTBG2015065_9 (HMAS-L0141556), XTBG2015066_1 (HMAS-L0139368), XTBG2015066_3 (HMAS-L0141557), XTBG2015066_4 (HMAS-L0141558), XTBG2015066_5 (HMAS-L0141559), XTBG2015066_6 (HMAS-L0141562), XTBG2015066_7 (HMAS-L0141563), XTBG2015067_1 (HMAS-L0139369), XTBG2015067_4 (HMAS-L0141561), XTBG2015067_5 (HMAS-L0141567), XTBG2015067_6 (HMAS-L0141564), XTBG2015069_1 (HMAS-L0139370), XTBG2015069_2 (HMAS-L0141565), XTBG2015069_4 (HMAS-L0141566), XTBG2015070_3 (HMAS-L0139371), XTBG2015071 (HMAS-L0139372), XTBG2015074_2 (HMAS-L0139373), XTBG2015074_3 (HMAS-L0141568), XTBG2015074_4 (HMAS-L0141568), XTBG2015075_2 (HMAS-L0139374), XTBG2015076 (HMAS-L0139375), XTBG2015077_4 (HMAS-L0139376); ibid.; 21 ${ }^{\circ} 54^{\prime} 35^{\prime \prime}$ N, 101 ${ }^{\circ} 16^{\prime} 52^{\prime \prime}$ E, $626 \mathrm{~m}$; on living leaves; 18 November 2015, X.L. Wei \& S.H. Jiang XTBG2015099_3 (HMASL0141570), XTBG2015118 (HMAS-L0139337). Jinghong County; $794 \mathrm{~m}$; on living leaves; 19 November 2015, X.L. Wei \& S.H. Jiang XTBG2015123_2 (HMASL0139340); ibid.; $22^{\circ} 19^{\prime} 15^{\prime \prime} \mathrm{N}, 100^{\circ} 47^{\prime} 13^{\prime \prime} \mathrm{E}, 968 \mathrm{~m}$; on living leaves; 28 October 2016, X.Y. Liu YN20160082 (HMAS-L0139194), YN20160087 (HMAS-L0139188),
YN20160093 (HMAS-L0139189); ibid.; 21 59' 04" N, $101^{\circ} 09^{\prime} 31^{\prime \prime} \mathrm{E}, 941 \mathrm{~m}$; on living leaves; 26 October 2016, YN20160146 (HMAS-L0139187).

5. Racoplaca Fée, Essai Crypt. Exot. (Paris): lxviii, xciv, xcix (1825) [1824].

MycoBank: MB 4640

Type species. Racoplaca subtilissima Fée.

Description: Thallus foliicolous, crustose, subcuticular, typically laciniate, composed of dichotomously branched lobes that form an attractively patterned radiating reticulum, individual lobes bordered by thin, black line. Photobiont Cephaleuros. Perithecia prominent, wart-shaped to conical, usually covered by a thin thallus layer up to the ostiole, therefore not pure black; excipulum prosoplectenchymatous, colorless; involucrellum carbonized, black; hamathecium colorless, I-, KI-; paraphyses unbranched, thin. Asci bitunicate, with short tholus and narrow, ocular chamber, I-, KI-, clavate to oblong. Ascospores 8 per ascus, biseriate or irregularly arranged, oblong to fusiform, 1-septate, colorless, $10-25 \times 2-5 \mu \mathrm{m}$. Pycnidia immersed-erumpent to adnate, wart-shaped to conical, usually black. Macroconidia bacillar to filiform, 1-septate, colorless, both ends with short gelatinous appendages (10-25 $\mu \mathrm{m}$, not exceeding $50 \mu \mathrm{m}$ even after prolonged time in squash mounts). Microconidia fusiform-ellipsoid non-septate, colorless.

Chemistry: No substances detected by TLC.

Notes: The genus Racoplaca is here reinstated for the species of the Strigula subtillissima group, characterized by thin, laciniate thalli with the margins bordered by a thin, black line. The genus is both phylogenetically and phenotypically distinctive. Besides the type species, the genus includes four further taxa.

\section{Key to species of Racoplaca}

1. Ascospores fusiform, $14-23 \times 3-5 \mu \mathrm{m}$ ......................................................2

1. Ascospores oblong, $8-18 \times 2-3 \mu \mathrm{m} . \ldots \ldots \ldots \ldots \ldots \ldots . . . . . . . .3$

2. Perithecia hemispherical to conical, up to $0.7 \mathrm{~mm}$ diam., greyish black ...............Racoplaca melanobapha

2. Perithecia wart-shaped to hemispherical, up to $0.4 \mathrm{~mm}$ diam., upper part exposed and black .Racoplaca tremens

3. Thallus dark green, with indistinct, mostly confluent laciniae......................... Racoplaca maculata

3. Thallus greenish brown to olive, with distinct, radiating laciniae.......................................... 4

4. Laciniae thickened, with conspicuous transverse undulations ..................Racoplaca transversoundulata

4. Lacinia thin, with even surface................. Racoplaca subtilissima 
Racoplaca maculata (Cooke \& Massee) S.H. Jiang, Lücking \& J.C. Wei, comb. nov.

MycoBank: MB 833584

Basionym: Micropeltis maculata Cooke \& Massee, in Cooke, Grevillea 18(86): 35 (1889).

Type: BRAZIL. Rio de Janeiro: Near Rio de Janeiro; 1889, Glaziou 18093 (lectotype, BM ex K!; Santesson 1952, p. 186).

Racoplaca melanobapha (Kremp.) S.H. Jiang, Lücking \& J.C. Wei, comb. nov.

MycoBank: MB 833586

Fig. 15

Basionym: Strigula melanobapha (Kremp.) R. Sant., Symb. bot. upsal. 12 (no. 1): 188 (1952).

Type: MALAYSIA. Sarawak: Borneo; 1866, Beccari 219 (holotype, M-0067744!).

Description: Thallus subcuticular, typically laciniate, forming thin, radiating, sometimes confluent lobes, individual lobes bordered by thin, black, interrupted line, $10-50 \mathrm{~mm}$ across and $10-15 \mu \mathrm{m}$ thick. Photobiont Cephaleuros, cells angular-rounded, 9-13 $\times 4-7 \mu \mathrm{m}$.
Perithecia exposed, covered by thin thallus, wart-shaped to conical, 0.4-0.7 mm diam. and 130-250 $\mu \mathrm{m}$ high, greyish black; Excipulum prosoplectenchymatous, 10-20 $\mu \mathrm{m}$ thick, color less to brown; Involucrellum carbonaceous, 30-50 $\mu \mathrm{m}$ thick, black. Asci narrowly obclavate, $70-110 \times 6-10 \mu \mathrm{m}$. Ascospores irregulary biseriate, fusiform, 1-septate, with constriction at septum, 14-22×3-5 $\mu \mathrm{m}$. Pycnidia wartshaped, those producing macroconidia $0.2-0.3 \mathrm{~mm}$, those producing microconidia $0.1-0.2 \mathrm{~mm}$ diam., black. Macroconidia bacillar, non-septate, $10-12 \times 2-3 \mu \mathrm{m}$, with appendages at both ends $15-25 \mu \mathrm{m}$ long. Microconidia fusiform, non-septate, $4-6 \times 1.5-2 \mu \mathrm{m}$.

Chemistry: No substances detected by TLC.

Distribution and ecology: This is presumed to be a pantropical species; it has been reported from Guiana, Peru, French Guiana, Brazil, Sierra Leone, and Borneo (Santesson 1952; Lücking 2008).

Notes: Racoplaca melanobapha is characterized by thallus composed of dichotomously branched lobes bordered by a thin, black, interrupted line that form an attractively patterned reticulum. Racoplaca subtilissima differs in the
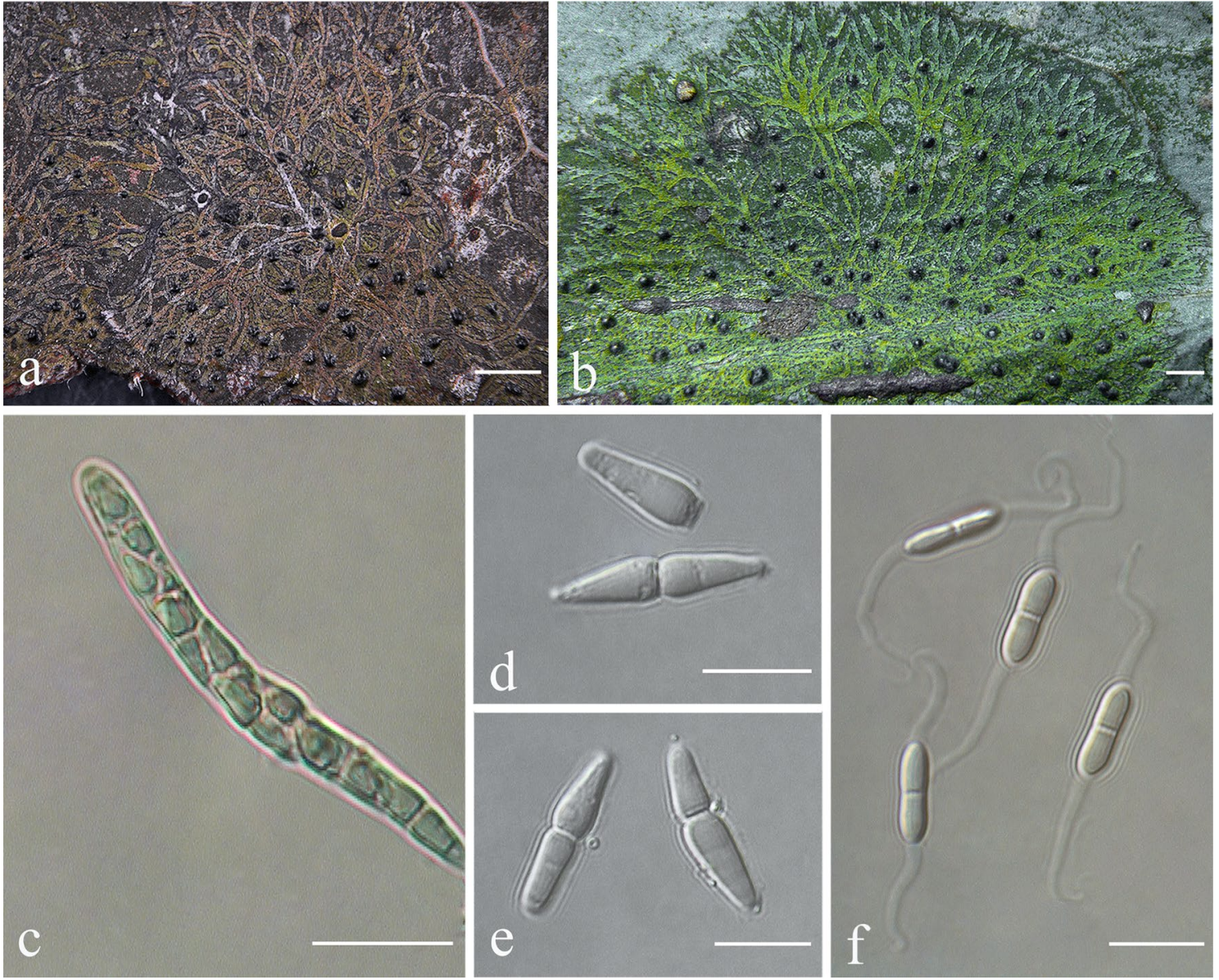

Fig. 15 Racoplaca melanobapha comb. nov. a Thallus (HMAS-L0139275), b Thallus (HMAS-L0139276), c Asci (HMAS-L0139275), d-e Ascospores (HMAS-L0139331), f Macroconidia (HMAS-L0139275). Scale bars: $\mathbf{a}=500 \mu \mathrm{m}, \mathbf{b}=600 \mu \mathrm{m}, \mathbf{c}=20 \mu \mathrm{m}, \mathbf{d}-\mathbf{f}=10 \mu \mathrm{m}$ 
smaller, narrower, oblong ascospores and the continuous black line, whereas $R$. maculata has a dark green thallus with short lobes. Racoplaca tremens has much smaller perithecia basally covered by a thick, thallus layer, apically exposed and pure black.

Additional specimens examined. CHINA. Guangdong: Ruyuan County, Nanling National Forest Park; 24 54' 59" $\mathrm{N}, 113^{\circ} 2^{\prime} 5^{\prime \prime} \mathrm{E}, 848 \mathrm{~m}$; on living leaves; 17 May 2015, X.L. Wei \& J.H. Wang GD2015066_3 (HMAS-L0141593); ibid.; $24^{\circ} 56^{\prime} 59^{\prime \prime} \mathrm{N}, 112^{\circ} 56^{\prime} 02^{\prime \prime} \mathrm{E}, 1257 \mathrm{~m}$; on living leaves; 17 May 2015, X.L. Wei \& J.H. Wang GD2015070 (HMAS-L0139173). Guangxi, Shangsi County, Shiwan Mountain Forest Park, along the way to Yingkesong and Jiulongsong; $21^{\circ} 53^{\prime} 46^{\prime \prime} \mathrm{N}, 107^{\circ} 53^{\prime} 59^{\prime \prime} \mathrm{E}, 636 \mathrm{~m}$; on living leaves; 25 May 2015, X.L. Wei \& J.H. Wang GX20150355 (HMAS-L0139275), GX20150362 (HMAS-L0139276); ibid.; $24^{\circ} 43^{\prime} 27^{\prime \prime} \mathrm{N}, 114^{\circ} 15^{\prime} 22^{\prime \prime} \mathrm{E}, 345 \mathrm{~m}$; on living leaves; 26 May 2015, X.L. Wei \& J.H. Wang GX20150347 (HMAS-L0139331); ibid.; $21^{\circ} 53^{\prime} 8^{\prime \prime} \mathrm{N}, 107^{\circ} 54^{\prime} 41^{\prime \prime} \mathrm{E}$, $657 \mathrm{~m}$; on living leaves; 25 May 2015, X.L. Wei \& J.H. Wang GX20150323 (HMAS-L0139328). Hunan: Chenzhou City, Mang Mountain National Nature Reserve; $24^{\circ} 56^{\prime} 59^{\prime \prime}$ N, $112^{\circ} 56^{\prime} 02^{\prime \prime}$ E, $1300 \mathrm{~m}$; on living leaves; 13 September 2017, S.H. Jiang HN20170489 (HMAS-L0139623), HN20170535 (HMAS-L0139620). AUSTRALIA. Queensland: Mount Spec State Forest, Paluma Range $6 \mathrm{~km} \mathrm{~W}$ of Paluma; J.A. Elix 20250 \& H. Streimann (CANB). Cook District, Kuranda; H. Streimann 61658 (CANB). Mossman Gorge, Daintree National Park, 6 km W of Mossman; H. Streimann 61677 p.p. (CANB).

Racoplaca transversoundulata (Sipman) S.H. Jiang, Lücking \& J.C. Wei, comb. nov.

MycoBank: MB 833589

Basionym: Strigula transversoundulata Sipman in van den Boom \& Sipman, Folia Cryptog. Estonica 53: 108 (2016).

Type: GUYANA. East Demerara District: Mabura Hill, near scientific field station c. $13 \mathrm{~km} \mathrm{~S}$ of the village; $5^{\circ} 18^{\prime}$ $\mathrm{N}, 58^{\circ} 42^{\prime} \mathrm{W}, 100 \mathrm{~m}$; undisturbed, c. $25 \mathrm{~m}$ tall forest on laterite on slope and in stream valley, foliicolous in undergrowth; 14 November 1992, H. Sipman 61761 (holotype, B 600200346 !).

Racoplaca tremens (Müll. Arg.) S.H. Jiang, Lücking \& J.C. Wei, comb. nov.

MycoBank: MB 833588

Basionym: Strigula tremens Müll. Arg., Flora, Regensburg 73: 200 (1890).

Type: BRAZIL. São Paulo: Apiahy; 1881, J.I. Puiggari s.n. (lectotype, G-G00126920!; Lücking 2008, p. 244).

6. Phylloporis Clem., Gen. Fung.: 41 (1909). MycoBank: MB 4070
Type species: Phylloporis phyllogena (Müll. Arg.) Clem.

Description: Thallus typically foliicolous, rarely on smooth bark of twigs or petioles, supracuticular, easily separated from leaf, continuous to marginally dispersed or dissected, smooth, very thin, greenish to grey. Photobiont Phycopeltis, forming somewhat radiating networks of rectangular cells. Perithecia erumpent to adnate and prominent, lens-shaped to wart-shaped or conical; excipulum prosoplectenchymatous, colorless; involucrellum carbonized, black; hamathecium I-, KI-; paraphyses unbranched, thin. Asci bitunicate, with short tholus and narrow ocular chamber, I-, KI-, clavate to oblong. Ascospores 8 per ascus, biseriate or irregularly arranged, fusiform, 1-septate, colorless, $7-15 \times 2-3 \mu \mathrm{m}$. Pycnidia erumpent to adnate, wart-shaped to conical, usually black. Macroconidia bacillar to filiform, 1 -septate, colorless, with short terminal appendages. Microconidia fusiform-ellipsoid non-septate, colorless.

Chemistry: No substances detected by TLC.

Notes: Species assigned to this genus were treated under the phylogenetically unrelated genus Porina by Santesson (1952), although he recognized the anatomical similarities with Strigula s.lat. Vézda (1984) resurrected the genus Phylloporis for this group and placed it close to Strigula, a classification accepted by subsequent workers (e.g. Lücking 1991). However, Harris (1995) subsumed the species within Strigula s.lat., a concept also followed by Lücking (2008). Our molecular data revealed Phylloporis as a distinct clade, which is accordance with its rather uniform phenotype features and the consistently supracuticular growth with a Phycopeltis-type photobiont. This underlines that while the photobiont itself cannot be considered a taxonomic feature of the mycobiont, the underlying selective mechanisms of the mycobiont to associate with that photobiont display a strong phylogenetic signal.

Besides the type, the genus includes seven further species, four of them already with names available in the genus: Phylloporis multipunctata (G. Merr. ex R. Sant.) Vězda, $P$. obducta (Müll. Arg.) R. Sant. \& Tibell, P. platypoda (Müll. Arg.) Vězda, and $P$. viridis Lücking. For three additional species, new combinations are required which are introduced below. The only species thus far detected in China is P. obducta; however, this identification is provisional, given that the type is from Brazil and considering that other presumably pantropical taxa, such as Strigula smaragdula, apparently consist of several species (see above).

\section{Key to species of Phylloporis}

1. Thallus with numerous small, black dots; ascospores partly breaking into part spores...................... 2

1. Thallus lacking black dots; ascospores remaining entire ..................................................... 3 
2. A s cospores $12-16 \times 3.5-4.5 \mu \mathrm{m}$ ........................ Phylloporis multipunctata

2. Ascospores $20-30 \times 4-6 \mu \mathrm{m}$

Phylloporis multipunctata

3. Photobiont cells forming contiguous, regularly radiating plates......................................... 4

3. Photobiont cells forming irregular to somewhat radiating networks with interspaces ........................ 5

4. Perithecia radiately elongate and drop-shaped when seen from above, exposed and black

Phylloporis vulgaris

4. Perithecia rounded with slightly spreading base, covered by distinct thallus layer, grey-green

Phylloporis viridis

5. Perithecia covered by distinct thallus layer, greygreen, wart-shaped, up to $0.3(-0.4) \mathrm{mm}$ diam.

\section{Phylloporis obducta}

5. Perithecia exposed or covered by thin thallus layer, black to greyish black, contrasting with the thallus, conical or with expanded base (Mexican hat-shaped), 0.3-0.7 mm diam.

4. Perithecia exposed or covered by thin thallus layer, black to greyish black, conical, $0.3-0.5 \mathrm{~mm}$ diam. Phylloporis phyllogena

4. 4. Perithecia covered by thin thallus layer, greyish black, with expanded base (Mexican hat-shaped), 0.5-0.7 mm diam.

Phylloporis platypoda

Phylloporis austropunctata (P.M. McCarthy) S.H. Jiang, Lücking \& J.C. Wei, comb. nov.

MycoBank: MB 833571

Basionym: Strigula austropunctata P.M. McCarthy, Fl. Australia 57: 661 (2009).

Phylloporis cf. obducta (Müll. Arg.) R. Sant. \& Tibell, Austrobaileya 2: 539 (1988).

Fig. 16
MycoBank: MB 134579

Basionym: Phylloporina obducta Müll. Arg., Flora 73: 198 (1890).

Type: BRAZIL. Rio de Janeiro: Near Rio de Janeiro; 1889, Glaziou 18086 (lectotype, G-G00292252!).

Description. Thallus foliicolous supracuticular, 7-20 mm across and 7-10 $\mu \mathrm{m}$ thick, smooth, pale grey. Photobiont Phycopeltis, cells rectangular, 5-14×3-5 $\mu \mathrm{m}$, forming slightly radiating networks with interspaces. Perithecia erumpent and typically covered by a distinct thallus layer up to ostiole, wart-shaped to conical, $0.2-0.4 \mathrm{~mm}$ diam. and 80-110 $\mu \mathrm{m}$ high, black; excipulum prosoplectenchymatous, 7-15 $\mu \mathrm{m}$ thick, colorless to brown; involucrellum carbonized, 12-25 $\mu \mathrm{m}$ thick, black; paraphyses unbranched. Asci oblong, 32-53 $\times 5-7 \mu \mathrm{m}$. Ascospores biseriate, fusiformellipsoid, 1-septate, with slight constriction at septum, $7-13 \times 2-3 \mu \mathrm{m}, 3.5-4.5$ times as long as broad. Pycnidia erumpent, covered by a distinct thallus layer, wart-shaped, those producing macroconidia $0.1-0.15 \mathrm{~mm}$, those producing microconidia rare, $0.07-0.1 \mathrm{~mm}$ diam., dark grey to greyish black. Macroconidia bacillar, 1-septate, $9-11 \times 2-2.5 \mu \mathrm{m}$. Microconidia fusiform-ellipsoid, nonseptate, $3-5 \times 1.5-1.8 \mu \mathrm{m}$.

Chemistry: No substances detected by TLC.

Distribution and ecology: Phylloporis obducta is a common, presumably pantropical species reported from Costa Rica, Panama, Columbia, Guiana, French Guiana, Ecuador, Brazil (including the type), Peru, the Philippines, and Australia, among other countries (Santesson 1952; Santesson and Tibell 1988; Lücking 2008). However, it is questionable whether this taxon constitutes a single species. Here reported for the first time from China.

Notes: Phylloporis obducta appears to be most closely related to Phylloporis phyllogena, from which it differs by smaller perithecia with a more rounded top, covered by a distinct, greenish to grey thallus layer (Lücking 2008). The
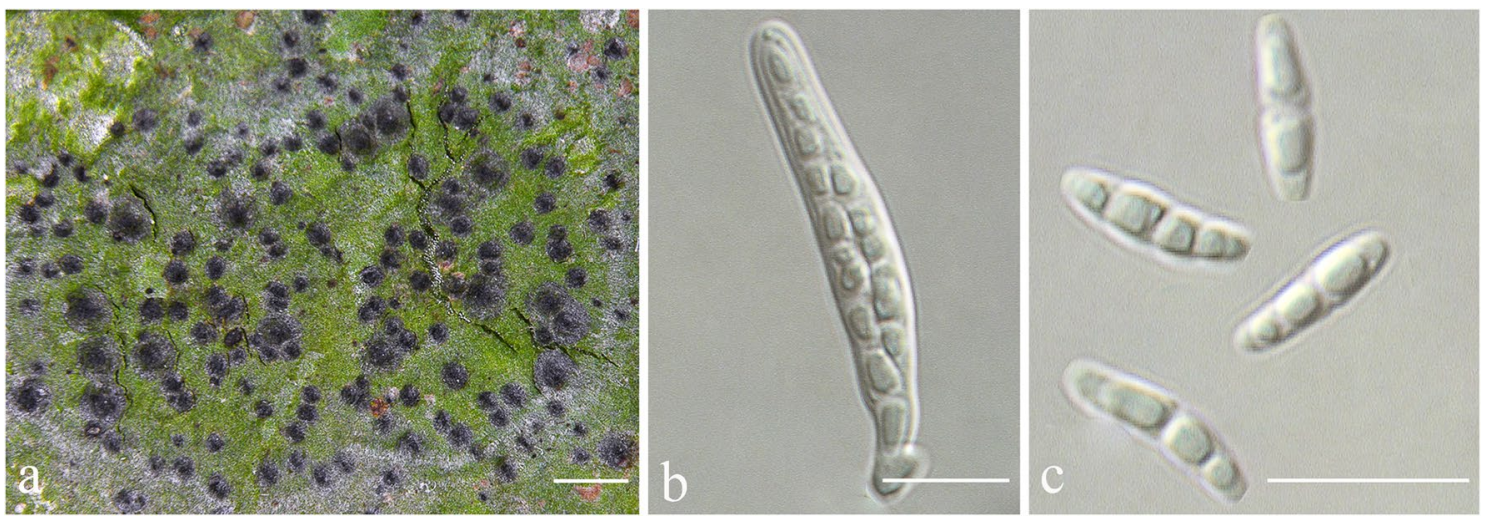

Fig. 16 Phylloporis cf. obducta. a Thallus (HMAS-L0139224), b Asci (HMAS-L0139237), c Ascospores (HMAS-L0139237). Scale bars: $\mathbf{a}=300 \mu \mathrm{m}, \mathbf{b}, \mathbf{c}=10 \mu \mathrm{m}$ 
identification of the sequenced Chinese material is preliminary; it differs in a rather thin covering thallus layer of the perithecia and the somewhat radiating arrangement of the perithecia, somewhat similar to $P$. vulgaris (Lücking 2008).

Additional specimens examined. CHINA. Guangxi: Longzhou County, Nonggang National Nature Reserve; $22^{\circ} 27^{\prime}$ $55^{\prime \prime} \mathrm{N}, 106^{\circ} 57^{\prime} 5^{\prime \prime} \mathrm{E}, 270 \mathrm{~m}$; on living leaves; 3 December 2015, S.H. Jiang GX201511203 (HMAS-L0139220), GX201511214 (HMAS-L0139224), GX201511217 (HMAS-L0139226), GX201511219 (HMAS-L0139218), GX201511222 (HMAS-L0139280), GX201511224 (HMAS-L0139281), GX201511302_3 (HMAS-L0141663), GX201511302_4 (HMAS-L0141664), GX201511233 (HMAS-L0139228), GX201511265_4 (HMAS-L0141658), GX201511272 (HMAS-L0139236), GX201511274 (HMAS-L0139237), GX201511302 (HMAS-L0139324), GX201511302_2 (HMAS-L0141662), GX201511308 (HMAS-L0139222), GX201511308_2 (HMAS-L0141665), GX201511309 (HMAS-L0139283), GX201511310 (HMAS-L0139282), GX201511311 (HMAS-L0139286), GX201511312 (HMAS-L0139284), GX201511315 (HMAS-L0139246), GX201511316 (HMAS-L0139247), GX201511317 (HMAS-L0139248), GX201511320 (HMAS-L0139251), GX201511329 (HMAS-L0139285). Hainan: Changjiang County, Bawangling National Nature Reserve; $19^{\circ} 07^{\prime} 07^{\prime \prime} \mathrm{N}, 109^{\circ} 09^{\prime} 12^{\prime \prime} \mathrm{E}, 700 \mathrm{~m}$; on living leaves; 4 September 2017, S.H. Jiang HN20171702 (HMASL0139635). Yunnan: Xishuangbanna, Mengla County, tropical botanical garden of Chinese Academy of Sciences, East area; $21^{\circ} 55^{\prime} 39^{\prime \prime} \mathrm{N}, 101^{\circ} 15^{\prime} 52^{\prime \prime} \mathrm{E}, 560 \mathrm{~m}$; on living leaves; 18 November 2015, X.L. Wei \& S.H. Jiang XTBG2015039 (HMAS-L0139351), XTBG2015039_2 (HMAS-L0141538), XTBG2015042_1 (HMAS-L0141574), XTBG2015045 (HMAS-L0139352), XTBG2015046 (HMAS-L0139357), XTBG2015046_2 (HMAS-L0141575), XTBG2015082 (HMAS-L0139377), XTBG2015087 (HMAS-L0139338), XTBG2015093 (HMAS-L0139339). AUSTRALIA. Queensland: Josephine Falls, Wooroonooran National Park, $20 \mathrm{~km} \mathrm{NW}$ of Innisfail; $17^{\circ} 26^{\prime} 16^{\prime \prime} \mathrm{S}, 145^{\circ} 51^{\prime} 33^{\prime \prime} \mathrm{E}, 80 \mathrm{~m}$; on leaves of trees in lowland, tropical rainforest; 31 July 2006, J.A. Elix 38767 (CANB).

Phylloporis radiata (Lücking) S.H. Jiang, Lücking \& J.C. Wei, comb. nov.

MycoBank: MB 833572

Basionym: Strigula radiata Lücking, Fl. Neotrop. Monogr. 103: 224 (2008).

Phylloporis vulgaris (Müll. Arg.) S.H. Jiang, Lücking \& J.C. Wei, comb. nov.

MycoBank: MB 833574

Basionym: Haplopyrenula vulgaris Müll. Arg., Flora 66: 273 (1883); Strigula vulgaris (Müll. Arg.) Lücking, Fl.
Neotrop. Monogr. 103: 221 (2008) [comb. inval., ICN Art. 41.5].

Acknowledgements Open Access funding was provided by Projekt DEAL. This project was supported by the National Natural Science Foundation of China (Project Nos. 31800010 and 31750001). The authors are indebted to Ms H. Deng in the Fungarium-Lichenum of the Institute of Microbiology, Chinese Academy of Sciences (HMASL), Dr. Patrick McCarthy in Australian National Herbarium, Centre for Australian National Biodiversity Research (CANB), Dr. Ulrike Starck in Botanischer Garten und Botanisches Museum Berlin (B), Dr. Marc Appelhans in the Herbarium, University of Goettingen (GOET), Dr. Andreas Beck in the Botanische Staatssammlung München (M), and Dr. Adrienne Stanton in the New Zealand Fungarium (PDD) for the loan of specimens. We also thank Emmanuël Sérusiaux and an anonymous reviewer for vaulable comments that helped to improve the manuscript considerably.

Author contributions SHJ, JCW, and RL conceived and designed the study. SHJ collected material in China and ABX-L, MESC, AA, RL, and CVP provided specimens from Brazil, Cuba and Guatemala. S.H. Jiang generated the DNA sequence data and SHJ and RL performed the phenotypic assessment of the material. SHJ and RL analysed the data. SHJ, RL, and JCW wrote the manuscript draft and all authors revised the draft and approved the final manuscript.

Open Access This article is licensed under a Creative Commons Attribution 4.0 International License, which permits use, sharing, adaptation, distribution and reproduction in any medium or format, as long as you give appropriate credit to the original author(s) and the source, provide a link to the Creative Commons licence, and indicate if changes were made. The images or other third party material in this article are included in the article's Creative Commons licence, unless indicated otherwise in a credit line to the material. If material is not included in the article's Creative Commons licence and your intended use is not permitted by statutory regulation or exceeds the permitted use, you will need to obtain permission directly from the copyright holder. To view a copy of this licence, visit http://creativecommons.org/licenses/by/4.0/.

\section{References}

Aptroot A, Diederich P, Sérusiaux E, Sipman HJM (1997) Lichens and lichenicolous fungi from New Guinea. Bibl Lichenol 64:1-220

Aptroot A, Ferraro LI, Lai MJ, Sipman HJM, Sparrius LB (2003) Foliicolous lichens and their lichenicolous ascomycetes from Yunnan and Taiwan. Mycotaxon 88:41-47

Aptroot A, Parnmen S, Lücking R, Baloch E, Jungbluth P, Cáceres MES, Lumbsch HT (2014) Molecular phylogeny resolves a taxonomic misunderstanding and places Geisleria close to Absconditella s. str. (Ostropales: Stictidaceae). Lichenologist 46:115-128. https://doi.org/10.1017/S0024282913000741

Baral HO (1987) Lugol's solution/IKI versus Melzer's reagent: hemiamyloidity, a universal feature of the ascus wall. Mycotaxon 29:399-450

Brooks F, Rindi F, Suto Y, Ohtani S, Green M (2015) The Trentepohliales (Ulvophyceae, Chlorophyta): an unusual algal order and its novel plant pathogen: Cephaleuros. Pl Dis 99:740-753. https ://doi.org/10.1094/PDIS-01-15-0029-FE 
Casacci LP, Barbero F, Balletto E (2014) The "evolutionarily significant unit" concept and its applicability in biological conservation. Ital J Zool 81:182-193. https://doi.org/10.1080/11250 003.2013.870240

Clements FE (1909) The genera of fungi. Wilson, Minneapolis

Cornejo C, Derr C, Dillman K (2017) Ricasolia amplissima (Lobariaceae): one species, three genotypes and a new taxon from south-eastern Alaska. Lichenologist 49:579-596. https://doi. org/10.1017/S002428291700041X

Eriksson OE (1982) [1981] The families of bitunicate ascomycetes. Opera Bot 60:1-209

Eriksson OE (2005) Outline of Ascomycota. Myconet 11:1-113

Eriksson OE, Baral HO, Currah RS, Hansen K, Kurtzman CP, Rambold G, Laessøe T (2004) Outline of Ascomycota. Myconet 10:1-99

Etayo J (1993) Strigula mediterranea, a new name for the forgotten lichen Porina schizospora. Lichenologist 25:257-260. https://doi. org/10.1006/lich.1993.1029

Fée ALA (1825) Essai sur les cryptogames des écorces exotiques officinales. F. Didot, Paris

Felsenstein J (1985) Confidence limits on phylogenies: an approach using the bootstrap. Evolution 39:783-791. https://doi. org/10.2307/2408678

Fries EM (1821) Beskrifning på nya Lafslägten. Första Styket Kongl Vetensk Akad Handl 2:320-330

Fries EM (1823) Systema mycologicum 2(2). Ex Officina Berlingiana, Lund

Fries EM (1830) Eclogae fungorum praecipue ex herbariis Germanorum descriptorum. Linnaea 5:497-533

Harris RC (1975) A taxonomic revision of the genus Arthopyrenia Massal. s. lat. (Ascomycetes) in North America. Ph. D Dissertation. Michigan State University, East Lansing

Harris RC (1995) More Florida Lichens. Including the 10c tour of the pyrenolichens. Published by the author, Bronx

Hawksworth D, James P, Coppins B (1980) Checklist of British lichenforming, lichenicolous and allied fungi. Lichenologist 12:1-115. https://doi.org/10.1017/S0024282980000035

Huhndorf SM, Harris RC (1996) Oletheriostrigula, a new genus for Massarina papulosa (Fungi, Ascomycetes). Brittonia 48:551-555. https://doi.org/10.2307/2807875

Hyde KD, Jones EBG, Liu JK, Ariyawansa H, Boehm E, Boonmee S, Braun U, Chomnunti P, Crous PW, Dai DQ, Diederich P, Dissanayake A, Doilom M, Doveri F, Hongsanan S, Jayawardena R, Lawrey JD, Li YM, Liu YX, Lücking R, Monkai J, Muggia L, Nelsen MP, Pang KL, Phookamsak R, Senanayake IC, Shearer CA, Suetrong S, Tanaka K, Thambugala KM, Wijayawardene NN, Wikee S, Wu HX, Zhang Y, Aguirre-Hudson B, Alias SA, Aptroot A, Bahkali AH, Bezerra JL, Bhat DJ, Camporesi E, Chukeatirote E, Gueidan C, Hawksworth DL, Hirayama K, Hoog SD, Kang JC, Knudsen K, Li WJ, Li XH, Liu ZY, Mapook A, McKenzie EHC, Miller AN, Mortimer PE, Phillips AJL, Raja HA, Scheuer C, Schumm F, Taylor JE, Tian Q, Tibpromma S, Wanasinghe DN, Wang Y, Xu JC, Yacharoen S, Yan JY, Zhang M (2013) Families of Dothideomycetes. Fung Div 63:1-313. https://doi.org/10.1007/s13225-013-0263-4

Jayalal U, Oh SO, Lücking R, Joshi S, Kim JA, Park JS, Hur JS (2013) Contributions to the foliicolous lichens flora of South Korea. Mycobiology 41:202-209. https://doi.org/10.5941/ MYCO.2013.41.4.202

Jiang SH, Wei XL, Wei JC (2016) Strigula sinoaustralis sp. nov. and three Strigula spp. new for China. Mycotaxon 131:795-803. https://doi.org/10.5248/131.795

Jiang SH, Wei XL, Wei JC (2017a) Two new species of Strigula (lichenised Dothideomycetes, Ascomycota) from China, with a key to the Chinese foliicolous species. MycoKeys 19:31-42. https://doi.org/10.3897/mycokeys.19.11174
Jiang SH, Wei XL, Wei JC (2017b) A new species and two new records of Strigula (lichenized Ascomycota) from China. Mycoscience 58:391-397. https://doi.org/10.1016/j.myc.2017.05.003

Jiang SH, Hawksworth DL, Lücking R, Wei JC (2020) A new genus and species of foliicolous lichen in a new family of Strigulales (Ascomycota: Dothideomycetes) reveals remarkable class-level homoplasy. IMA Fungus 11:1. https://doi.org/10.1186/s4300 8-019-0026-2

Kalyaanamoorthy S, Minh BQ, Wong TKF, von Haeseler A, Jermiin LS (2017) ModelFinder: fast model selection for accurate phylogenetic estimates. Nat Methods 14:587-589. https://doi. org/10.1038/nmeth.4285

Katoh K, Toh H (2010) Parallelization of the MAFFT multiple sequence alignment program. Bioinformatics 26:1899-1900. https://doi.org/10.1093/bioinformatics/btq224

Krishnamurthy YL, Kumar SS (2017) Foliicolous lichens of central Western Ghats, India: diversity, distribution and molecular study. LAP LAMBERT Academic Publishing, Saarbrücken, $\mathrm{p}$ 240

Krishnamurthy YL, Subramanya SK (2016) Phenotype and genotype based cladistic analysis of the genus Strigula (foliicolous lichens) present in the Western Ghats region of Karnataka, India. Int Multidiscip Sci GeoConf 3:317-324

Liu YJ, Whelen S, Hall BD (1999) Phylogenetic relationships among ascomycetes: evidence from anRNA polymerase II subunit. Mol Biol Evol 16:1799-1808. https://doi.org/10.1093/oxfordjournals. molbev.a026092

Llarens L (2003) Estudios taxonómicos y morfológicos de Strigula Fr. (Strigulaceae), Ascomycetes liquenizados folifcolas de Argentina. Comun Cienc Tecnol 2003: Resumen B-003

Lücking R (1991) Neue Arten foliikoler Flechten aus Costa Rica, Zentralamerika. Nova Hedw 52:267-304

Lücking R (1992) Foliicolous lichens: a contribution to the knowledge of the lichen flora of Costa Rica, Central America. Beih Nova Hedw 104:1-179

Lücking R (2008) Foliicolous lichenized fungi, vol 103. Published for the organization for Flora Neotropica by the New York Botanical Garden Press, Bronx, pp 1-866

Lücking R, Aptroot A, Thor G (1997) New species or interesting records of foliicolous lichens. II. Flavobathelium epiphyllum (lichenized Ascomycetes: Melanommatales). Lichenologist 29:221-228. https://doi.org/10.1006/lich.1996.0079

Lücking R, Hodkinson BP, Leavitt SD (2017) The 2016 classification of lichenized fungi in the Ascomycota and Basidiomycota: approaching one thousand genera. Bryologist 119:361-416. https ://doi.org/10.1639/0007-2745-119.4.361

McCarthy PM (1995) New saxicolous species of Strigula Fr. (lichenised Ascomycotina: Strigulaceae) from Australia and New Zealand. Muelleria 8:323-329

McCarthy PM (1997) New and interesting saxicolous species of Strigula. Lichenologist 29:513-523. https://doi.org/10.1006/ lich.1997.0109

McCarthy PM (2001) The lichen genus Strigula in Christmas Island, Indian Ocean. Biblioth Lichenol 78:275-288

McCarthy PM (2009a) Strigulaceae. Fl Aust 57(570-584):593-601

McCarthy PM (2009b) A new foliicolous species of Strigula (Strigulaceae) from New South Wales. Austral Lichenol 65:4-6

McCarthy PM, Malcolm WM (1996) Strigula occulta, a new saxicolous lichen from New Zealand. Mycotaxon 60:323-326

Montagne JFC (1845) Criptogamia o plantas cellulares. Ramon de la Sagra, Historia Física, Política y Natural de la Isla de Cuba, vol 9. A. Bertrand, Paris, pp 1-96

Moritz C (1994) Defining 'evolutionarily significant units' for conservation. Trends Ecol Evol 9:373-375. https://doi. org/10.1016/0169-5347(94)90057-4 
Nelsen MP, Lücking R, Grube M, Mbatchou JS, Muggia L, Rivas Plata E, Lumbsch HT (2009) Unravelling the phylogenetic relationships of lichenized fungi in Dothideomyceta. Stud Mycol 64:135-144. https://doi.org/10.3114/sim.2009.64.07

Nelsen MP, Rivas Plata E, Andrew CJ, Lücking R, Lumbsch HT (2011a) Phylogenetic diversity of trentepohlialean algae associated with lichen-forming fungi. J Phycol 47:282-290. https://doi. org/10.1111/j.1529-8817.2011.00962.x

Nelsen MP, Lücking R, Mbatchou JS, Andrew CJ, Spielmann AA, Lumbsch HT (2011b) New insights into relationships of lichenforming Dothideomycetes. Fung Div 51:155-162. https://doi. org/10.1007/s13225-011-0144-7

Nelson SC (2008) Cephaleuros species, the plant-parasitic green algae. P1 Disease 43:1-6

Nguyen LT, Schmidt HA, von Haeseler A, Minh BQ (2015) IQ-TREE: a fast and effective stochastic algorithm for estimating maximumlikelihood phylogenies. Mol Biol Evol 32:268-274. https://doi. org $/ 10.1093 / \mathrm{molbev} / \mathrm{msu} 300$

Orange A, James PW, White FJ (2001) Microchemical methods for the identification of lichens. British Lichen Society, London

Piercey-Normore MD, Depriest PT (2001) Algal switching among lichen symbioses. Am J Bot 88:1490-1498. https://doi. org/10.2307/3558457

Posada D (2008) Jmodeltest: phylogenetic model averaging. Mol Biol Evol 25:1253-1256. https://doi.org/10.1093/molbev/msn083

Rambaut A (2012) FigTree v1.4.2. http://tree.bio.ed.ac.uk/software/ figtree

Rehner SA, Buckley E (2005) A Beauveria phylogeny inferred from nuclear ITS and EF1- $\alpha$ sequences: evidence for cryptic diversification and links to Cordyceps teleomorphs. Mycologia 97:84-98. https://doi.org/10.1080/15572536.2006.11832842

Rogers SO, Bendich AJ (1988) Extraction of DNA from plant tissues. In: Gelvin SB, Schilperoort RA, Verma DPS (eds) Plant molecular biology manual. Kluwer Academic Publishers, Dordrecht, pp $1-10$

Ronquist F, Teslenko M, Mark PVD, Ayres DL, Darling A, Höhna S, Larget B, Liu L, Suchard MA, Huelsenbeck JP (2012) MrBayes 3.2: efficient Bayesian phylogenetic inference and model choice across a large model space. Syst Biol 61:539-542. https://doi. org/10.1093/sysbio/sys029

Roux C, Sérusiaux E (1995) Présence d'appendices mucoïdes sur les ascospores de Raciborskiella janeirensis (Müll. Arg.) R. Sant. Bull Soc Linn Provence 46:91-94

Roux C, Sérusiaux E (2004) Le genre Strigula (lichens) en Europe et en Macaronésie. Biblioth Lichenol 90:1-96
Santesson R (1952) Foliicolous lichens I. A revision of the taxonomy of the obligately foliicolous, lichenized fungi. Symb Bot Ups 12(1): $1-590$

Santesson R, Tibell L (1988) Foliicolous lichens from Australia. Austrobaileya 2:529-545

Sérusiaux E (1997) Strigula macaronesica, a new species of foliicolous lichen from Gomera and Madeira. Lichenologist 29:333-337. https://doi.org/10.1006/lich.1997.0082

Sérusiaux E, Polly B (1996) Strigula kaitokensis sp. nov. from New Zealand. Mycotaxon 59:245-251

Singh A (1970) Strigula and Raciborskiella species from the Andaman Islands, India. Bryologist 73:719-722. https://doi. org/10.2307/3241288

Spegazzini CL (1881) Fungi Argentini additis nonnullis brasilensibus montevideensibusque. An Soc Cient Argent 12(3):97-117

Stamatakis A (2014) Raxml version 8: a tool for phylogenetic analysis andpost-analysis of large phylogenies. Bioinformatics 30:13121313. https://doi.org/10.1093/bioinformatics/btu033

Swinscow TDV (1967) Pyrenocarpous lichens: 12 The Genus Geisleria. Lichenologist 3:418-422. https://doi.org/10.1017/S0024 28296700043X

Vézda A (1984) Foliikole Flechten der Insel Kuba. Folia Geobot Phytotax 19:177-210. https://doi.org/10.1007/BF02853060

White TJ, Bruns TD, Lee SB, Taylor JW (1990) Amplification and direct sequencing of fungal ribosomal RNA genes for phylogenetics. In: Innis MA, Gelfand DH, Sninsky JJ, White TJ (eds) PCR Protocols: a guide to methods and applications. Academic Press, New York, pp 315-322

Woo JJ, Lücking R, Oh SY, Jeun YC, Hur JS (2020) Two new foliicolous species of Strigula (Strigulaceae, Strigulales) in Korea offer insight in phorophyte-dependent variation of thallus morphology (in press)

Zahlbruckner A (1898) Beiträge zur Flechtenflora Niederösterreichs V. Verhandl Kaiserl-Königl Zool-Bot Gesellsch Wien 48:349-370

Zhu H, Zhao ZJ, Xia S, Hu ZY, Liu GX (2014) Morphology and phylogenetic position of Stomatochroon reniformis var. chinensis var. nov. (Trentepohliales, Ulvophyceae), a rare endobiotic alga from China. Phycologia 53:493-501. https://doi.org/10.2216/14-010.1

Zhu H, Hu Z, Liu G (2017) Morphology and molecular phylogeny of Trentepohliales (Chlorophyta) from China. Eur J Phycol 52:330341. https://doi.org/10.1080/09670262.2017.1309574 